\title{
Implications of myocardial dysfunction before and after \\ aortic valve intervention
}

Henrik Hultkvist

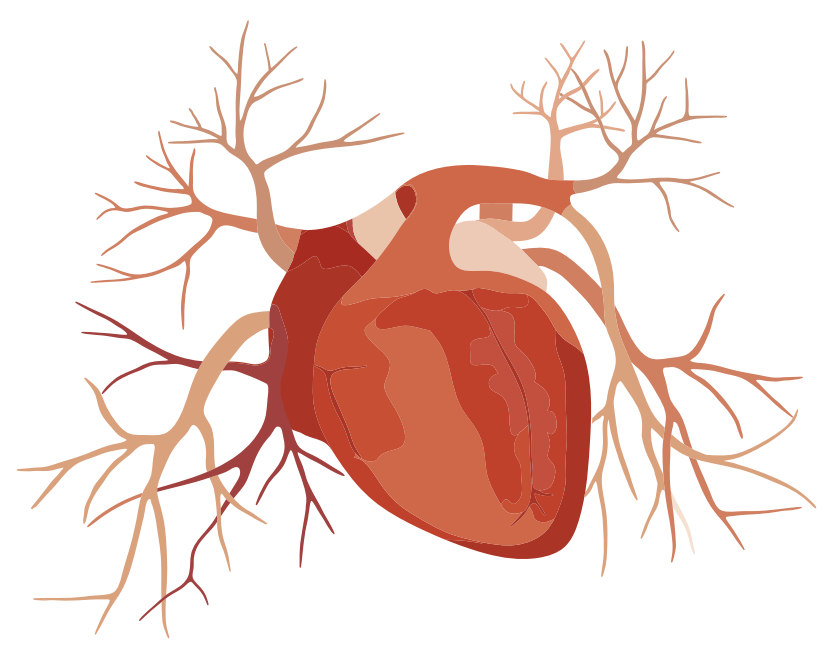




\title{
Implications of myocardial dysfunction before and after aortic valve intervention
}

\author{
Henrik Hultkvist
}

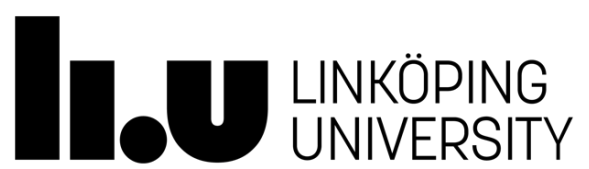

Department of Medical and Health Sciences Linköping University, Sweden Linköping 2019 
(c)Henrik Hultkvist, 2019

Cover illustration: istockphoto

Published article has been reprinted with the permission of the copyright holder.

Printed in Sweden by LiU-Tryck, Linköping, Sweden, 2019

ISBN 978-91-7685-079-4

ISSN $0345-0082$ 
To Louise, Olivia and Wilhelm

To the relief of my supervisors! 



\section{CONTENTS}

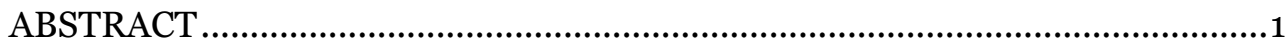

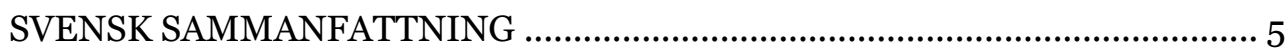

Betydelsen av hjärtdysfunktion vid aortaklaffkirurgi .................................... 5

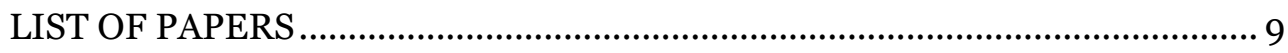

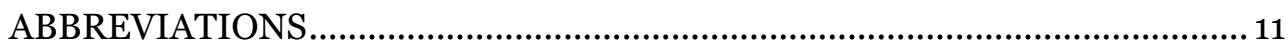

ACKNOWLEDGEMENTS ………............................................................13

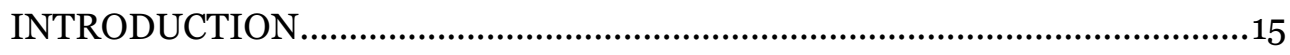

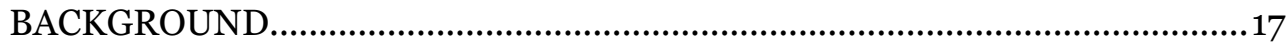

The heart and the valves ...............................................................................17

Chronic aortic regurgitation ..................................................................... 18

Aortic stenosis ............................................................................................19

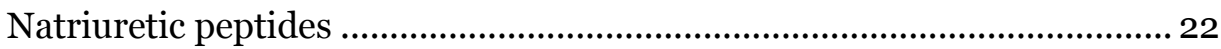

Diastolic function .......................................................................................... 23

Aortic valve intervention................................................................................ 24

Myocardial dysfunction in aortic valve surgery ........................................... 25

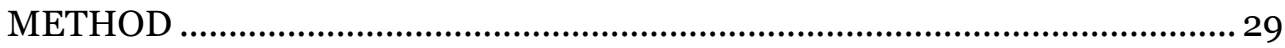

Study design and patients .............................................................................. 29

Data collection ....................................................................................... 30

Clinical management..................................................................................... 30

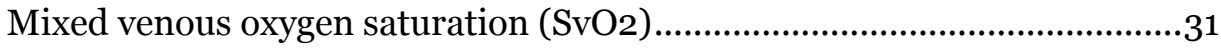

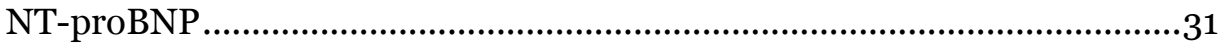

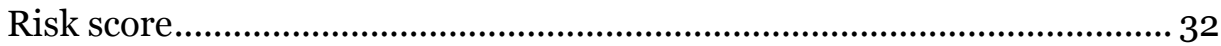

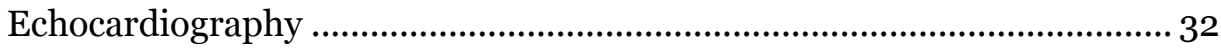

Clinical endpoints committee …................................................................. 36

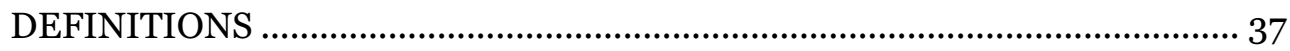

Postoperative heart failure.......................................................................... 37

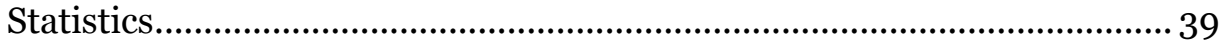

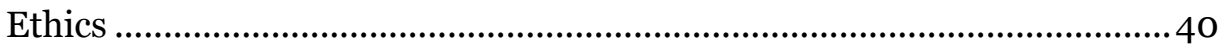

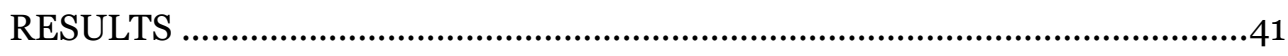

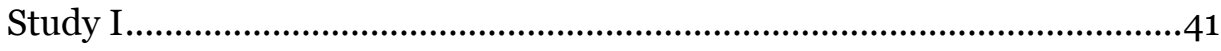

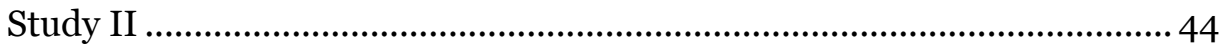

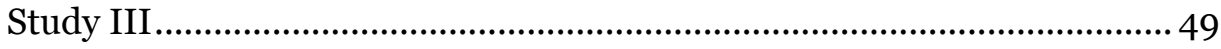

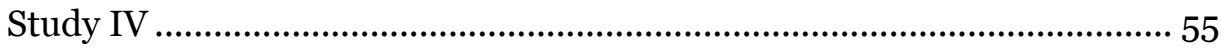




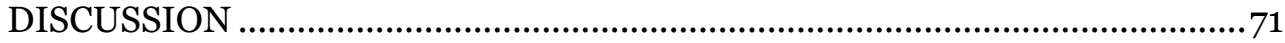

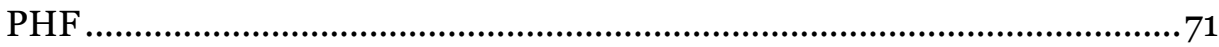

NT-proBNP and PHF ................................................................................. 73

Diastolic dysfunction, NT-proBNP and PHF ……….................................... 76

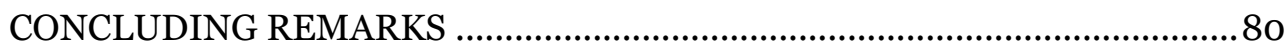

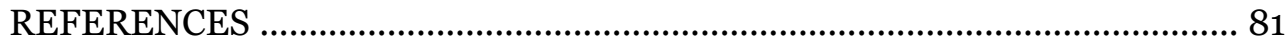




\section{ABSTRACT}

\section{BACKGROUND}

Postoperative heart failure in the setting of aortic valve surgery results in poor long-term survival. We hypothesized that there could be a myocardial factor that is not addressed by risk scores currently available. We speculated that this myocardial factor could be diastolic dysfunction. By evaluating postoperative heart failure, the EuroSCORE, the NT-proBNP level, and diastolic function, we might achieve a deeper understanding of the outcome for individuals with postoperative heart failure.

\section{METHODS}

This research project was built upon four cohort studies. The first two studies (I and II) were retrospective in nature, and studies III and IV were prospective, observational, and longitudinal. All work was based on data from clinical and national databases. In Study I, we compared the outcome of patients with or without postoperative heart failure, evaluated according to the preoperative risk score. In Study II, we explored the effect of underlying heart disease on the preoperative level of NT-proBNP and the relationships between NT-proBNP and severe postoperative heart failure and short-term mortality. In Study III, we described the dynamics of NT-proBNP, from a preoperative evaluation to a six-month follow-up, in patients that underwent one of two different procedures: a surgical aortic valve replacement and a transcatheter implantation. We related both pre- and postprocedural NT-proBNP levels to one-year mortality. In Study IV, we evaluated diastolic function in patients that underwent sur- 
gical aortic valve replacement and its influence on outcome. We also evaluated NT-proBNP levels and postoperative heart failure as predictors of long-term mortality.

\section{RESULTS}

\section{Study I}

This study included 397 patients that underwent isolated surgical aortic valve replacements. Of these, 45 patients (11\%) were treated for postoperative heart failure. With an average follow-up of 8.1 years (range 5.211.2), among patients at low risk (EuroSCORE $\leq 7$ ), the crude five-year survival rates were $58 \%$ in patients with postoperative heart failure and $89 \%$ in those without postoperative heart failure ( $\mathrm{p}<0.001$ ). Among patients with postoperative heart failure, those classified as low risk had the same poor long-term prognosis as those classified as high risk (EuroSCORE $>7$ ). In the high risk group, survival rates were similar between patients with or without postoperative heart failure (57\% vs. $64 \%$; $\mathrm{p}=0.60)$.

\section{Study II}

This study included a cohort of 2978 patients with coronary artery disease, aortic stenosis, and mitral regurgitation. Preoperative NTproBNP levels were found to be 1.7-fold higher in patients with aortic stenosis than in patients with coronary artery disease and 1.4-fold higher in patients with mitral regurgitation than in patients with coronary disease. The power of preoperative NT-proBNP for predicting severe postoperative heart conditions was good among patients with coronary heart disease and patients with mitral regurgitation, but not as good among patients with aortic stenosis. NT-proBNP also showed good discriminating power for short-term mortality among patients with coronary artery dis- 
ease. Moreover, NT-proBNP was found to be an independent predictor for both severe postoperative heart failure and short-term mortality in patients with coronary artery disease.

\section{Study III}

This study included 462 patients that underwent preoperative evaluations for aortic valve disease. Aortic valve interventions elicited a rise in NT-proBNP that was more pronounced in patients undergoing surgical aortic valve replacement compared to patients undergoing transcatheter valve implantation. No deterioration in NT-proBNP was observed during the waiting time before the intervention, despite a median duration of four months. At six months after the intervention, NT-proBNP levels had decreased to or below the preoperative levels in all groups. Among patients that received surgical aortic valve replacements, pre-and early postoperative NT-proBNP levels showed good discriminatory power for oneyear mortality. This discriminatory power was not observed among patients that had undergone a transcatheter procedure; those patients had higher levels of both pre- and postoperative NT-proBNP compared to patients that had undergone surgery.

\section{Study IV}

We evaluated 273 patients that underwent aortic valve surgery. High left ventricular filling pressure was present in $22 \%(n=54)$ of patients at the time of surgery. At six months after surgery, diastolic function deteriorated in 24/193 (12\%) patients and improved in 27/54 (50\%) patients. Diastolic dysfunction was not found to be associated with long-term mortality. However, both postoperative heart failure and preoperative NTproBNP levels were associated with increases in long-term mortality. In a multivariable Cox analysis, NT-proBNP remained predictive of long-term mortality. 


\section{CONCLUSION}

Postoperative heart failure contributed to long-term mortality, even in patients considered to be at low risk preoperatively. Our results suggested that pressure overload, followed by a volume overload led to a NTproBNP response that was more pronounced than the ischemia response. Elevated levels of NT-proBNP were associated with both short- and longterm mortality. In these studies, we could not corroborate the notion that high left ventricular filling pressure was associated with long-term mortality. 


\section{SVENSK SAMMANFATTNING}

\section{Betydelsen av hjärtdysfunktion vid aortaklaffkirurgi}

Aortaklaffsjukdomar (förträngd och/eller läckande klaff) är vanliga i västvärlden och ökar med stigande ålder, särskilt åldersrelaterad förträngning av aortaklaffen. Vid läckande aortaklaff måste hjärtat arbeta med en allt större blodvolym. Vid aortaklaffsförträngning krävs att hjärtat genererar ett högre tryck än normalt för att pumpa blodet genom den förträngda klaffen. Båda typerna av klaffel leder till att hjärtat kompenserar för den ökade belastningen och det kan gå många år innan symtom uppträder. Till slut räcker inte kompensationsmekanismerna till och hjärtat börjar svikta och typiska symtom som andnöd, kärlkramp och svimning tillstöter. Någon effektiv medicinskt botande behandling finns inte varför enda alternativet är att ersätta eller reparera klaffen. Idag finns två metoder för detta, öppen hjärtkirurgi och kateterburen insättning av aortaklaffen. Båda typerna av ingrepp har risker som kan påverka utfallet efter ingreppet. Inför varje ingrepp görs en riskvärdering för att om möjligt optimera behandlingen. Inte sällan utgörs den största riskbelastningen av hjärtats funktion som i olika grad kan vara påverkad av underliggande hjärtsjukdom. Tidigare forskning har visat att hjärtsvikt i samband med operation av aortaklaffen är relaterat till sen överdödlighet och i det här avhandlingsarbetet ville vi närmare studera faktorer som kan vara del av den överdödligheten vid aortaklaffintervention.

Vi har valt att studera betydelsen av postoperativ hjärtsvikt hos patienter som före operation bedömdes ha låg respektive hög risk att inte överleva ingreppet. Resultaten visar att lågriskpatienter som efter operation drabbas av hjärtsvikt har en lika starkt reducerad långtidsöverlevnad som den hos högriskpatienter med hjärtsvikt. I avhandlingen visar vi att förträngning av aortaklaffen med tryckbelastning på hjärtat ger ett större svar av 
hjärtsviktshormonet NT-proBNP i jämförelse med patienter med volymsbelastat hjärta och de med kranskärlssjukdom. Vidare visar vi att hjärtsviktshormonet NT-proBNP med hög grad av säkerhet kan identifiera kranskärlspatienter med ökad risk för svår svikt och död på kort sikt.

Vi beskriver också det dynamiska förloppet av hjärtsviktshormonet NTproBNP hos patienter med förträngning av aortaklaffen samt det svar som de två operationsmetoderna har på hormonet. Öppen hjärtkirurgi leder till en kraftig stegring med en topp vid tredje dagen efter operation. Kateterburen insättning av klaffen ger ett lägre svar och en tidigare topp redan dagen efter klaffinsättningen. Efter 6 månader har de förhöjda värdena sjunkit till eller under de värden som fanns innan ingreppet. Vi visar även att förhöjda värden av hjärtsviktshormonet före operation och tidigt efter operation är kopplat till ökad dödlighet under det första året efter operation. Den kopplingen sågs inte vid kateterburen klaffinsättning. Tjugotvå procent av patienterna som opererades för förträngd aorta klaff uppvisade tecken på nedsatt diastolisk hjärtfunktion med förhöjda fyllnadstryck. Efter operation hade hälften av dessa förbättrats och uppvisade inte längre tecken till förhöjda fyllnadstryck vid ultraljudsundersökning av hjärtat. Hos en mindre andel, 12 \% sågs en försämring av den diastoliska funktionen 6 månader efter kirurgi. Både postoperativ hjärtsvikt och förhöjda värden av hjärtsviktshormonet NT-proBNP visade sig vara kopplade till reducerad överlevnad på lång sikt. Vi kunde dock inte finna att förhöjda fyllnadstryck i sig hade någon koppling till reducerad överlevnad på lång sikt. 
Sammanfattningsvis visar avhandlingsarbetet att postoperativ hjärtsvikt fortsatt är av stor betydelse för prognosen av hjärtopererade patienter. Vi visar att hjärtsviktshormonet NT-proBNP har god prediktiv förmåga för såväl kort- och långtidsprognos och därför bör vara en del av den preoperativa riskevalueringen. Vi har visat att den diastoliska funktionsnedsättningen kan förbättras efter aortaklaffkirurgi men att en del även försämras. Vi kunde inte visa att diastolisk funktionsnedsättning med förhöjda fyllnadstryck är kopplat till död på lång sikt. 
Implications of myocardial dysfunction before and after aortic valve intervention 


\section{LIST OF PAPERS}

\section{Henrik Hultkvist, Farkas Vánky, Rolf Svedjeholm}

The Combined Impact of Postoperative Heart Failure and EuroSCORE on Long-Term Outcome after Surgery for Aortic Stenosis The Journal of heart valve disease. 2011;20(6):633-8.

II Huiqi Jiang, Henrik Hultkvist, Jonas Holm, Farkas Vánky, Yangi Yang, Rolf Svedjeholm

Impact of underlying heart disease per se on the utility of preoperative NT-proBNP in adult cardiac surgery

PloS one. 2018;13(2):e0192503.

III Henrik Hultkvist, Jonas Holm, Rolf Svedjeholm, Farkas Vánky

Rise and fall of NT-proBNP in aortic valve intervention Open heart. 2018;5(1):e0oo739.

IV Henrik Hultkvist, Eva Nylander, Éva Tamás, Rolf Svedjeholm, Jan Engvall, Jonas Holm, Eva Maret, Farkas Vánky

Evaluation of left ventricular diastolic function in patients operated for aortic stenosis, an observational study

Manuscript 
Implications of myocardial dysfunction before and after aortic valve intervention 


\section{ABBREVIATIONS}

A

AF

AP

AR

AS

AUC

AVR

BMI

BSA

CABG

CAD

CCS

CCT

$\mathrm{CHF}$

COPD

CPB

DM

E

é

ECC

EDV

EF

EOA

EuroSCORE
Late diastolic filling velocity

Atrial fibrillation

Angina pectoris

Aortic regurgitation

Aortic stenosis

Area under the curve

Aortic valve replacement

Body mass index

Body surface area

Coronary artery bypasses grafting

Coronary artery disease

Canadian Cardiovascular Society Functional Classification of Angina

Cross clamp time

Congestive heart failure

Chronic obstructive pulmonary disease

Cardiopulmonary bypass

Diabetes mellitus

Early diastolic filling velocity

Early diastolic myocardial velocity

Extra corporeal circulation

End diastolic volume

Ejection fraction

Effective orifice area

European System for Cardiac Operative Risk Evaluation 
GFR Glomerular filtration rate

IABP Intra Aortic Balloon Pump

ICU Intensive care unit

IVRT Isovolumic relaxation time

LAA Left atrial area

LV Left ventricle/ ventricular

LVEDD Left ventricular end diastolic dimension

LVEDV Left ventricular end diastolic volume

LVESV Left ventricular end systolic volume

LVOT Left ventricular outflow tract

MR Mitral regurgitation

NT-proBNP N-terminal fragment of brain natriuretic peptide

NYHA New York Heart Association

PAD Peripheral artery disease

PHF Postoperative heart failure

PHT Pulmonary hypertension

PMI Perioperative myocardial infarction

PPM Prosthesis-patient mismatch

PVL Paravalvular leakage

Redo Reoperation

ROC Receiver operating characteristic

SAVR Surgical aortic valve replacement

$\mathrm{SvO} 2 \quad$ Mixed venous oxygen saturation

TAVI Transcatheter aortic valve implantation 


\section{ACKNOWLEDGEMENTS}

Financial support was received from the Medical Research Council of Southeast Sweden (FORSS) and ALF grants from County Council of Östergötland and Linköping University, Sweden.

I would like to express my gratitude to everyone who has helped me in this research project, especially:

Farkas Vánky, my principal supervisor for the tenacity over the years. You are a great inspiration, both clinically and scientifically.

Rolf Svedjeholm my co-supervisor for scientific guidance and support, I really enjoyed the trips we took abroad presenting our results.

Jonas Holm, my co-supervisor for encouraging conversations and endless support.

I would like to thank all my co-authors, especially Eva Nylander, Éva Tamás and Jan Engvall for constructive criticism and inspiring scientific discussions.

All the colleagues in Norrköping, Jönköping, and Kalmar for the collection of data, especially Miriam Johansson at the Department of Clinical Physiology, Linköping, for the enormous works on the EKO-data base. Thank you, Maj-Britt Tornell and Inger Huljebrandt for the help with this project.

My current head and former heads of the Department of Cardiothoracic and Vascular Surgery, in allowing me to pursue the scientific path. All my colleagues for their support and understanding during my absence from the clinic.

Louise, Olivia and Wilhelm, the love of my life. 
Implications of myocardial dysfunction before and after aortic valve intervention 


\section{INTRODUCTION}

Myocardial dysfunction is not uncommon in aortic valve disease, and postoperative heart failure is a major contributor to mortality in this setting ${ }^{1}$. Aortic valve interventions are among the most frequently performed cardiac procedures in the Western world today ${ }^{2}$. The incidence of degenerative calcific aortic valve disease increases with age and, due to the aging of the world population, it is expected to increase even more in future 3 . When the disease is severe and patients are symptomatic, life expectancy is substantially reduced in the absence of a valve disorder correction 4 . Patients that become symptomatic are often older with comorbidities, and the valve disorder has led to adaptive, and eventually, maladaptive changes, which result in myocardial dysfunction. The only efficient treatment available is aortic valve replacement. Although life expectancy is nearly normalized after an aortic valve replacement 5 , the procedures themselves can cause intraoperative trauma, which affects the outcome in both the short and long runs ${ }^{6-9}$.

The concept of this dissertation emerged from the recognition that patients with heart failure after surgery for aortic valve stenosis had a dire prognosis after a few years, even when the initial course was apparently benign. We speculated that postoperative heart failure (PHF) might unmask a previously unknown myocardial factor that has not been addressed by currently available risk scores.

In cardiac surgery, evaluating risks is pivotal, and those risks are, to a high degree, dependent on the patient's condition, preoperative comorbidities, and cardiac function, in addition to the type of surgery. Historically, much attention has been paid to left ventricular (LV) systolic function. One of the most commonly used risk scores, the European System for Cardiac Operative Risk Evaluation (EuroSCORE), uses the ejection fraction (EF) to evaluate LV systolic function, among other parameters ${ }^{10}$. 
However, in addition to systolic function, other aspects of heart function might impact prognosis. We hypothesized that a subtle, preclinical myocardial dysfunction, which is not revealed in classic risk evaluations, might play a role before systolic dysfunction becomes apparent.

In this project, we studied myocardial dysfunction in different aortic valve interventions, with special references to PHF, NT-proBNP (N-terminal pro B-type natriuretic peptide), and diastolic dysfunction. 


\section{BACKGROUND}

\section{The heart and the valves}

The normal heart acts as a pump, constantly providing our cells with oxygenated blood and nourishment. The cardiac cycle is divided into diastole, when the heart relaxes and fills, and systole, when the heart contracts and empties. Effective pump function is possible through the intricate orientation of the muscle fibers in the heart, which was explained by Torrent Guasp in $1957{ }^{11}$. According to T-G, the myocardial fibers are oriented in inner longitudinal layer, circumferentially in the middle and spiral in the outer layer, forming a myocardial band. This can be seen as a statistical distribution of cells and does not have to be physically reproduced in the real world. The middle circumferential layer reduces the intraventricular lumen during contraction. The apical portion of the ventricle contracts before the basal portion, which drives the blood towards the aortic valve. The longitudinal and spiral muscles pull the mitral valve towards the apex. The three different orientations of muscle fibers provide a highly efficient way for the heart to pump and receive blood during each cardiac cycle. This structure allows rotation and torsion, followed by recoiling, with each cardiac cycle ${ }^{11,12}$. However, the concept of a myocardial band has recently been questioned, and a new model that involves a threedimensional (3D) myocardial mesh has been suggested ${ }^{13}$, 14 . With the aid of high resolution microcomputed tomography, it was shown that cardiomyocytes are arranged within a supportive fibrous matrix, which constitutes a $3 \mathrm{D}$ mesh ${ }^{14}$. The concept of a myocardial band was assumed to be a simplification to facilitate our understanding of the structure and function of the ventricles.

In each heart cycle, the right side of the heart pulls blood out of the veins and pumps the blood to the lungs. Then, the left side of the heart simulta- 
neously pulls the blood out of the lungs and pumps it into the systemic circulation ${ }^{15}$. To accomplish these tasks, the competencies of the heart valves are of utmost importance. The valve leading into the right ventricle is called the tricuspid valve, and the valve leading into the left ventricle is called the mitral valve. The outlet valves of the heart normally have three cusps (tricuspid valves). The two outlet valves are the pulmonary valve, which allows blood to pass into the lungs, and the aortic valve, which allows blood to pass into the aorta. When a valve begins to leak, the heart must deal with increasing volume overload; when a valve becomes stenotic, the heart must compensate for flow obstruction. Initially, the heart adapts to these changes, but further volume or pressure overload will eventually lead to a failing heart, when left untreated.

\section{Chronic aortic regurgitation}

In aortic regurgitation, the aortic valves do not close normally, and blood leaks back from the aorta into the ventricle. This condition can be caused by diseases that affect the valve apparatus or by pathology that affects the aortic root ${ }^{16}$. As the end-diastolic volume increases, the left ventricular dimensions increase to compensate for excessive volume overload and also pressure overload ${ }^{17}$. In aortic regurgitation there is a widened pulse pressure (systolic blood pressure-diastolic blood pressure) due to the extra volume being pumped into the aorta during systole. The pressure overload is caused by the systolic hypertension as a result from increased stroke volume ${ }^{17}$. The ventricle compensates by dilating, through eccentric hypertrophy. In eccentric hypertrophy, sarcomeres replicate in a serial pattern. Conversely, in aortic stenosis, the heart compensates with concentric hypertrophy, where sarcomeres replicated in a parallel pattern ${ }^{18}$. Over time, the compliance of the ventricle adapts, and the ventricle can handle a larger volume, which leads to a decrease in diastolic pressure. Although not fully understood, this sequence of events might explain why 
the ventricle eventually decompensates. Indeed, an imbalance between a high LV stroke volume (observed in aortic regurgitation) and a reduced diastolic pressure can lead to reduced subendocardial perfusion and repeated episodes of ischemia 9. Ventricular dilatation and hypertrophy can compensate for the volume overload for years before symptoms arise, but eventually, ventricular remodelling occurs, in both systolic and diastolic dysfunctions ${ }^{19}$.

\section{Aortic stenosis}

In aortic stenosis, the valve does not open as expected, and the leaflets become stiff and non-compliant. Three major processes are associated with aortic valve stenosis: degenerative calcification of the aortic valve, calcific degeneration of congenital bicuspid valves, and rheumatic valve stenosis.

The incidence of calcific degenerative aortic stenosis, with or without concomitant regurgitation, is increasing due to the growing older population in Western cultures ${ }^{2}$. Globally, the incidence of rheumatic fever and its effects on the heart has exceeded the incidence of degenerative calcification and its effects on aortic valve stenosis ${ }^{20}$. Calcific degeneration of the aortic valve occurs in two phases. The first is an inflammatory phase with lipid deposition, not unlike atherosclerosis; the second is a later phase with calcific mineralization, not unlike bone formation ${ }^{21,22}$. To overcome the resistance of a stenotic valve, the heart compensates with left ventricular concentric hypertrophy, which reduces the wall stress in the left ventricle ${ }^{23}$. Ultimately, this initial compensatory hypertrophy hampers LV relaxation and compliance, and the LV cannot fill at low atrial pressures. When this condition remains untreated, survival rapidly declines in symptomatic patients ${ }^{24}$. Typical symptoms consist of shortness of breath, angina, and syncope; however, the variability between patients is large, particularly among older individuals. In older patients, it might be diffi- 
cult to detect a transition from asymptomatic to symptomatic stages, due to a gradual decline in the patient's physical activity and the slow progression of symptoms. Therefore, clinical guidelines have recommended that the patient's symptoms should be recorded, a thorough evaluation of the circulatory and respiratory systems should be conducted, and the heart should be evaluated via echocardiographic examinations ${ }^{25}$, 26. Left untreated, a progressive narrowing of the aortic valve will lead to a failing heart, and ultimately death, due to the increased workload imposed on the heart. The only option is to replace the valve, because no effective medical treatment is currently available.

\section{Echocardiography}

Echocardiography has become a cornerstone in the evaluation and surveillance of patients with aortic valve disease ${ }^{25-27}$. Echocardiography allows the visualization of heart anatomy and function. With echocardiographic analyses, the degree of valvular lesions can be quantified and both systolic and diastolic functions can be assessed ${ }^{28}$. In medical ultrasound, a high-frequency energy beam of 2-10 mega Hertz (MHz), which is not audible to humans, is sent through the body and reflected (echoed) back to the generating transducer, which produces an image. Two-dimensional (2D) echocardiography generates very short bursts of ultrasound in 2-3 wavelengths, which generates an image of the heart. This technique enables us to see, for example, the aortic valve and the cavities of the heart. It generates a real-time image of the moving heart. This approach facilitates evaluations of valvular pathology and the extent of ventricular hypertrophy or dilation, in addition to systolic function. When ultrasound is reflected against moving objects, it changes frequencies. When the object moves towards the transducer, the frequency of the reflecting sound will increase; conversely, when an object moves away from the transducer, the frequency of the reflecting sound will decrease. This principle is used in 
Doppler echocardiography. With Doppler echocardiography, blood erythrocytes are the moving objects, and by assessing the velocity of blood flowing through the valve, it is possible to calculate the aortic valve area and the severity of aortic stenosis. 


\section{Natriuretic peptides}

The natriuretic peptide family consists of three peptides: atrial natriuretic peptide (ANP), brain natriuretic peptide (BNP), and C-type natriuretic peptide (CNP) ${ }^{29}$. Accordingly, three natriuretic peptide receptors (A, B, and $\mathrm{C}$ ) have been identified in mammalian tissues. Natriuretic peptide receptors A and B are linked to the cGMP-dependent signalling cascade. These receptors mediate many of the effects of natriuretic peptides on the cardiovascular and renal systems. In addition, BNP binds to natriuretic peptide receptor $\mathrm{C}$, which is involved in the clearance of natriuretic peptides. BNP is an endogenous hormone that is mostly produced in cardiac tissue. It was first found in brains of pigs in 1988, hence the name BNP (B for brain) ${ }^{30}$. Its main functions are to maintain cardio-renal function and to counteract some features of heart failure. Its effects include diuresis, vasodilation, anti-hypertrophy, anti-fibrosis, and inhibition of the sympathetic nervous system and the renin-angiotensin-aldosterone system ${ }^{31}$. $\mathrm{BNP}$ and its N-terminal fragment are released from a pre-prohormone in myocytes and exported into the circulation in response to increased left ventricular filling pressure and wall tension (Fig. 1) ${ }^{32,33 .}$

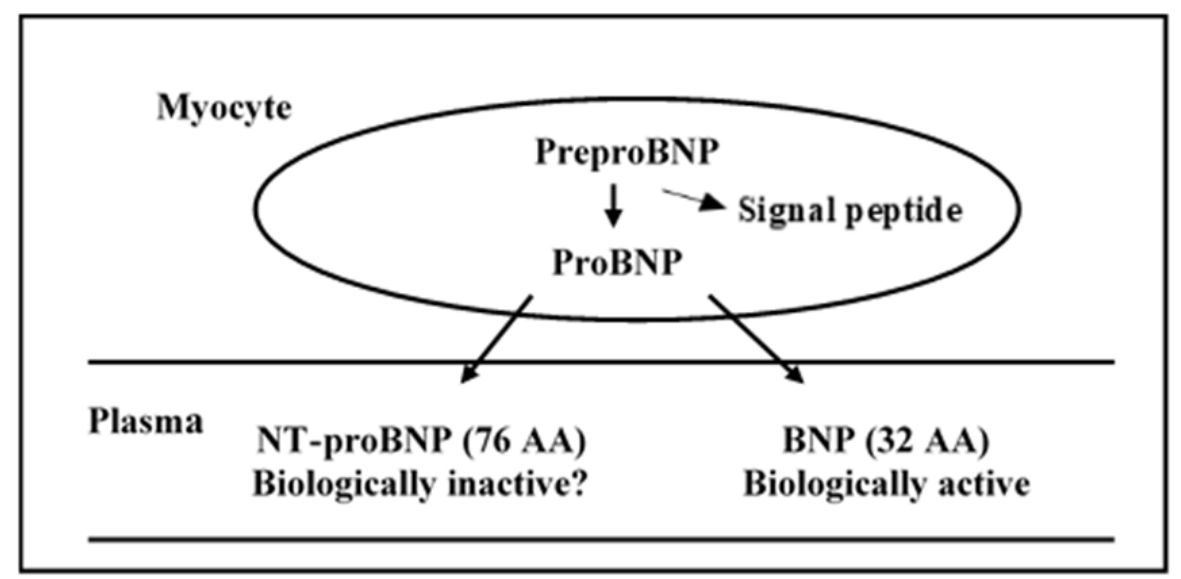

Figure 1. Synthesis and secretion of PreproBNP by the cardiomyocytes processed to ProBNP by enzymatic convertases Corin and Furin. The presumed inactive $N$-terminal fragment is secreted into the circulation alongside the active $C$-terminal BNP. Reprinted with permission from Jonas Holm. 
BNP and its inert N-terminal fragment (NT-proBNP) are released in a 1:1 ratio into the circulation. BNP has a shorter half-life (21 $\mathrm{min}$ ) than NTproBNP (60-120 min) 32, 34. Currently, NT-proBNP is an established biomarker for diagnosing and monitoring heart failure 35, 36. Moreover, NT-proBNP is elevated in a variety of cardiovascular disorders ${ }^{36}$. NTproBNP was correlated with the severity of aortic stenosis. In symptomatic patients, it was shown to be predictive of mortality $37-39$. In cardiac surgery, NT-proBNP was related to the short-term outcome and the length of stay in an Intensive Care Unit (ICU) 40-42. However, studies on its usefulness have produced conflicting results 43,44 . In aortic valve surgery, preoperative NT-proBNP was found to be predictive of poor postoperative outcome 45,46 , but its predictive power was considered to be moderate 47 , 48. NT-proBNP was also correlated to diastolic function 49-52.

\section{Diastolic function}

Diastolic relaxation is when the myocardium returns to a relaxed tension and length before systole. Diastole is often described as the period that starts with closure of the aortic valve and ends with closure of the mitral valve. Diastole can be divided into three phases: in phase one, the muscles relax and blood rapidly fills the ventricle; phase two is diastasis, where the passive filling of the ventricle has slowed down; and phase three is enddiastole, which is marked by active atrial contraction 53 . Diastolic relaxation is an active, calcium-dependent process, which mainly influences early left ventricular filling. Ventricular compliance, described as the change in volume over pressure $(\mathrm{dV} / \mathrm{dP})$, is most important towards the end of diastole. The opposite of compliance is ventricular stiffness $(\mathrm{dP} / \mathrm{dV})$.

All these features of diastolic function are negatively affected by a hypertrophic myocardium, which occurs in aortic valve diseases, particularly aortic stenosis. The severity of diastolic dysfunction can be assessed with 
the echo-Doppler technique. The process of diastolic dysfunction starts with abnormal relaxation, although filling pressures often remain normal, at least at rest. In severe diastolic dysfunction, compliance is reduced, which results in increased left ventricular filling pressures.

Diastolic function is graded as normal, Grade I (impaired relaxation pattern), Grade II (pseudonormalization), and Grade III (restrictive filling pattern). Grades II and III are thought to be associated with increased LV filling pressure. Diastolic dysfunction often precedes systolic dysfunction in aortic valve disease 54,55 . The prevalence of diastolic dysfunction is reported to be high in patients with aortic valve disease, and it has been associated with outcomes after interventions 56-59. Diastolic dysfunction was also associated with a poor prognosis in patients with AS that had not undergone surgery ${ }^{60}$. Although diastolic dysfunction was also found to be associated with a poor outcome after an aortic valve intervention, conflicting data exist ${ }^{61,62}$.

\section{Aortic valve intervention}

Currently, aortic valves can be replaced with surgery or with a transcatheter aortic valve intervention (TAVI). Before the TAVI era, patients deemed unfit for open heart surgery were predestined for an early death, due to aortic valve disease ${ }^{63}$. In 1953, Hufnagel and Harvey performed the first surgical replacement of an aortic valve by inserting a caged ball valve in the descending aorta. They operated on a patient with aortic insufficiency, which caused insufficient blood flow in the upper body 64 . However, it was not until the early 1960's that the first successful aortic valve replacements were performed, with the aid of the heart-lung machine constructed by Gibbon in $1954^{64}$. Currently, aortic valve interventions are among the most common cardiac procedures performed around the world 3, 65. The first TAVI procedure in humans was performed in $2002{ }^{66}$. Since then, this procedure has grown enormously popular ${ }^{67}$. 
Aortic valve prostheses for surgical insertions can be either mechanical or biological. Biological prostheses can be made of autologous tissue, from diseased tissue, or more commonly, from a porcine aortic valve or a valve constructed from bovine pericardium. Mechanical valves have the advantage of durability, but on the downside, they increase the risk of thrombus formation and the risk of an embolic event. Therefore, patients with mechanical valves require life-long anticoagulant medication, which increases the risk of serious bleeding. Biological valves do not require anticoagulant medication, but they have limited durability, due to structural deterioration over time. After aortic valve replacement, regardless of the type of valve, there is a risk of a prosthesis-patient mismatch, where the effective orifice area of the implanted valve is too small for the patient's body surface area 68,69 . Other postoperative complications include arrhythmias and atrioventricular blocks, which require a postoperative pacemaker implantation, and other complications related to open-cardiac surgery, per se, such as bleeding, tamponade, and infections. Complications associated with TAVI include access site bleeding and infection, the need for a postoperative pacemaker, stroke ${ }^{70}$, and periprocedural myocardial infarction 71,72 .

\section{Myocardial dysfunction in aortic valve surgery}

Since the early 1980's, it has been recognized that myocardial dysfunctions can occur in the context of aortic valve replacement 73 . Indeed, cardiac interventions alone impose an ischemic injury to an already failing heart, due to the underlying pathology ${ }^{74}$. Preoperatively, there is often an imbalance between oxygen delivery and demand, which can be due to an obstruction in the coronary arteries, a hypertrophied myocardium, or an increase in the cardiac workload. Both anesthesia and surgery impose additional stress, which affects both oxygen delivery and demand. Anemia frequently occurs, due to hemodilution caused by the bypass circuit or 
due to bleeding. Tachycardia is not uncommon, because the surgical trauma induces increased levels of circulating catecholamines, amongst many other stressors. During cardiac arrest, the myocardium can be protected from ischemia with a cold cardioplegic solution, which minimizes cardiac metabolic activity. The remaining metabolism is anaerobic, and it depletes myocytes of certain metabolites; this depletion can cause depressed myocardial function in the early postoperative phase 75.

Over the decades, mortality in cardiac surgery has decreased, despite an increase in surgical complexity ${ }^{76}$. However, PHF continues to be among the most important causes of mortality associated with cardiac surgery and aortic valve interventions 6, 77 . Among patients undergoing aortic valve surgery, PHF was associated with $38 \%$ short-term mortality, compared to $1.5 \%$ in the absence of PHF 78 . Both systolic and diastolic function has been found to impact the outcome of an aortic valve intervention 79, 80. Previous studies have identified both pre- and intraoperative risk factors for PHF 81-83. Studies on patients that have undergone non-cardiac surgery have shown that the best therapeutic approach to heart failure in the surgical setting is to perform proper patient risk stratification ${ }^{84}$. In the setting of elective cardiac surgery, myocardial dysfunction can be considered its own entity; many patients require inotropes to prevent endorgan dysfunction and tissue hypoperfusion ${ }^{85}$. In our experience, approximately $10 \%$ of patients that undergo aortic valve surgery for AS developed PHF 7. Other studies have reported that more than $20 \%$ of patients undergoing cardiac surgery exhibited perioperative myocardial dysfunction 86 


\section{AIMS OF THE THESIS}

We attempted to understand why, among patients that underwent surgery for aortic valve disease; those that experienced an episode of PHF had much worse survival after a few years compared to those without PHF. We hypothesized that there might be a myocardial factor that has not been identified with typical preoperative risk evaluations.

The specific aims for each study were:

I. To describe the impact of PHF on long-term survival after surgery for isolated aortic valve stenosis in patients at low and high risk identified with a commonly used cardiac surgery risk score model, the EuroSCORE.

II. To investigate the underlying role of heart disease, per se, on preoperative NT-proBNP levels in patients admitted for adult cardiac surgery, after adjusting for known confounders, including age, gender, obesity, and renal function. In addition, we investigated the value of NT-proBNP for predicting severe PHF and postoperative mortality.

III. To describe the levels of preoperative NT-proBNP and changes in these levels from enrollment to the six-month follow-up, in patients undergoing aortic valve interventions, and to evaluate the association between preoperative NT-proBNP and one-year mortality.

IV. To explore how aortic valve surgery for aortic stenosis impacted LV diastolic function. In addition, we evaluated the impacts of high LV filling pressure, NT-proBNP, and PHF on postoperative outcome. 
Implications of myocardial dysfunction before and after aortic valve intervention 


\section{METHOD}

\section{Study design and patients}

The patient populations and study designs of the four studies in this project are summarized in Table 1.

Table 1. Methodological overview of included studies.

\begin{tabular}{|c|c|c|c|c|}
\hline Study & I & II & III & IV \\
\hline Design & $\begin{array}{l}\text { Retrospective } \\
\text { cohort }\end{array}$ & $\begin{array}{l}\text { Retrospective } \\
\text { cohort }\end{array}$ & $\begin{array}{l}\text { Prospective, } \\
\text { observational, } \\
\text { longitudinal }\end{array}$ & $\begin{array}{l}\text { Prospective, } \\
\text { observational, } \\
\text { longitudinal }\end{array}$ \\
\hline Pathophysiology & AS & $\begin{array}{l}\mathrm{CAD}, \mathrm{AS} \text { and } \\
\mathrm{MR}\end{array}$ & $\begin{array}{l}\mathrm{AS} \pm \mathrm{CAD} \text { and } \\
\mathrm{AR}\end{array}$ & $\mathrm{AS} \pm \mathrm{CAD}$ \\
\hline Exposure & SAVR & $\begin{array}{l}\text { CABG, SAVR } \\
\text { and mitral } \\
\text { valve repair or } \\
\text { MVR }\end{array}$ & SAVR or TAVI & SAVR \\
\hline Period & $1995-2000$ & 2010-2016 & 2008-2013 & $2008-2013$ \\
\hline $\begin{array}{l}\text { Patients includ- } \\
\text { ed }\end{array}$ & 397 & 2978 & 462 & 247 \\
\hline $\begin{array}{l}\text { Primary out- } \\
\text { come }\end{array}$ & Late mortality & $\begin{array}{l}\text { The role of } \\
\text { underlying } \\
\text { heart disease } \\
\text { on NT-proBNP }\end{array}$ & $\begin{array}{l}\text { Describe the } \\
\text { dynamics of } \\
\text { NT-proBNP }\end{array}$ & $\begin{array}{l}\text { The effect of } \\
\text { SAVR on LV } \\
\text { diastolic func- } \\
\text { tion }\end{array}$ \\
\hline $\begin{array}{l}\text { Secondary out- } \\
\text { comes }\end{array}$ & $\begin{array}{l}\text { Impact of Eu- } \\
\text { roSCORE }\end{array}$ & $\begin{array}{l}\text { Predictive } \\
\text { power of NT- } \\
\text { proBNP on } \\
\text { severe PHF } \\
\text { and early mor- } \\
\text { tality }\end{array}$ & $\begin{array}{l}\text { Predictive } \\
\text { power of NT- } \\
\text { proBNP on } 1 \\
\text { year mortality }\end{array}$ & $\begin{array}{l}\text { Relate high LV } \\
\text { filling pres- } \\
\text { sure, PHF and } \\
\text { NT-proBNP on } \\
\text { outcome }\end{array}$ \\
\hline Statistics & $\begin{array}{l}\text { Descriptive, } \\
\text { survival analy- } \\
\text { sis }\end{array}$ & $\begin{array}{l}\text { Descriptive, } \\
\text { survival analy- } \\
\text { sis, linear re-- } \\
\text { gression, lo- } \\
\text { gistic regres- } \\
\text { sion and ROC } \\
\text { analyses }\end{array}$ & $\begin{array}{l}\text { Descriptive, } \\
\text { survival analy- } \\
\text { sis, correlation, } \\
\text { linear regres- } \\
\text { sion and ROC } \\
\text { analyses }\end{array}$ & $\begin{array}{l}\text { Descriptive, } \\
\text { survival analy- } \\
\text { sis, Cox regres- } \\
\text { sion correla- } \\
\text { tion, linear } \\
\text { regression and } \\
\text { ROC analyses }\end{array}$ \\
\hline
\end{tabular}

$A S=$ aortic stenosis, $C A D=$ coronary artery disease, $M R=$ mitral regurgitation, $A R=$ aortic regurgitation, $S A V R=$ surgical aortic valve replacement, $M V R=$ mitral valve replacement, TAVI=transcatheter aortic valve implantation, $N T$-proBNP= $N$-terminal fragment of brain natriuretic peptide, EuroSCORE= European System for Cardiac Operative Risk Evaluation, ROC=Receiver Operating Characteristic 


\section{Data collection}

We accessed the patient records registry maintained in our institution with Summit Vista for Windows (Summit Medical Systems INC., Version 1.98.1), in study I, and with Carath version 5.4 (Fujitsu Inc.), in studies II - IV. Additional data were retrieved from patient records (studies I - IV) and from Case Report forms (studies III and IV). Mortality data were retrieved from the Swedish Civil Registry. Causes of death were retrieved from medical records and from autopsy records (study II).

\section{Clinical management}

All patients were treated at the University Hospital in Linköping, a tertiary referral hospital and the only center for cardiac surgery in the southeast region of Sweden. This hospital served a population of approximately one million. For all patients undergoing surgery, standardized surgical and anesthetic techniques were used. Surgery included a full median sternotomy, heparinization, and a cardiopulmonary bypass with aortic crossclamping, followed by antegrade or combined ante- and retrograde cardioplegic arrest, repeated every 20 minutes. After surgery, weaning from bypass was instituted at a rectal temperature of $35-36^{\circ} \mathrm{C}$. The heparin effect was reversed with protamine chloride. In study I, a cold crystalloid cardioplegia solution was used, and shed postoperative blood was routinely collected and retransfused into the patient in the ICU. In studies IIIV, a diluted blood cardioplegia solution was prepared with four parts crystalloid cardioplegia solution diluted with one part blood. In those studies, no retransfusion of shed postoperative blood was performed.

Patients undergoing TAVI were placed under general anesthesia with endotracheal intubation. Access was achieved through either a transthoracic or transfemoral pathway. For the transthoracic TAVI implantation, a small, left-sided thoracotomy was performed, and the valve was deployed 
via the apex of the heart. This access route was chosen when the common femoral artery was small ( $<7-8 \mathrm{~mm}$ diameter) or when the iliofemoral arteries were severely calcific. The procedure was aided with both fluoroscopy and transoesophageal echocardiography. In all TAVI cases, an expandable Edwards Sapien valve bioprosthesis (Edwards Lifesciences Inc., Irvine, CA) was implanted.

\section{Mixed venous oxygen saturation (SvO2)}

A surgically introduced pulmonary catheter was routinely used to collect blood samples of $\mathrm{SvO}_{2}$ and to monitor pulmonary artery pressures, particularly during weaning from the bypass ${ }^{87} \cdot \mathrm{SvO}_{2}$ was routinely monitored in the ICU, and it was used to optimize circulation postoperatively. Oxygen saturation was analyzed in an ABL50o (study I), an ABL725, or an ABL825 (studies II - IV; Radiometer Medical ApS, Brønshøj, Denmark).

\section{NT-proBNP}

Venous blood samples were collected in lithium heparin tubes and analyzed within 3 hours to determine NT-proBNP levels. NT-proBNP was measured with an electrochemoluminescence immunoassay on a Roche Elecsys 2010 automated platform (Roche Diagnosis, Basel, Switzerland) in studies II - IV. Briefly, NT-proBNP concentrations were measured with a sandwich technique, with polyclonal antibodies that recognized epitopes on the N-terminal part of proBNP. In study II, preoperative NT-proBNP was analyzed. In study III, we analyzed NT-proBNP at preoperative evaluation before decision was made by a multi-disciplinary heart team on intervention, the day before index procedure, postoperatively on the first and third postoperative day and at the 6 months follow-up. In study IV, we analyzed NT-proBNP the day before surgery and at the six-month fol- 
low-up. The inter-assay coefficient of variation was $4 \%$, on average. The age-adjusted upper reference limits were: $450 \mathrm{ng} / \mathrm{L}$ for patients $<50$ years old, $900 \mathrm{ng} / \mathrm{L}$ for those 50-75 years old, and $1800 \mathrm{ng} / \mathrm{L}$ for those $>75$ years old 88,89 .

\section{Risk score}

To assess risk, we employed the additive EuroSCORE, calculated retrospectively, in studies I and II, and we used EuroSCORE II prospectively in studies III and IV. In study I, patients were divided into two groups, based on their preoperative additive EuroSCOREs. Patients with EuroSCOREs $>7$ were assigned to a high-risk group, and patients with EuroSCOREs $\leq 7$ were assigned to a low-risk group. Patients were then analyzed according to whether they developed PHF. One might argue that dividing the cohort into two groups, based on the EuroSCORE, was insufficient, and that the norm, based on the literature, would be to divide the cohort into quartiles. However, the sample size and number of events were too few to permit an analysis of four groups. The clear difference in outcome between the two groups verified the clinical relevance of this stratification. However, the EuroSCORE has been known to overestimate the operative risk of mortality, particularly in patients with a high-risk preoperative profile ${ }^{\circ}$.

\section{Echocardiography}

All patients were preoperatively examined and evaluated with standard 2D and Doppler echocardiography to assess myocardial function and the severity of valvular pathology. All measurements were performed according to guidelines ${ }^{91,92}$.

The mean pressure difference ("gradient") over a stenotic valve is often a good measure of the severity of a stenosis. The pressure difference can be calculated with the simplified Bernoulli equation: $\Delta \mathrm{P}=4^{*} \mathrm{v}^{2}$, were $\Delta \mathrm{P}$ is 
the pressure fall over the stenosis, and $\mathrm{v}$ is the flow velocity in the vena contracta zone on the distal end of the stenosis. We calculated the mean gradient by tracing the flow velocity curve during systole. The pressure fall depends on the flow over the stenosis. In cases with low flow, for example, in depressed myocardial function, the severity of the stenosis might be underestimated. The aortic valve area (AVA) -that is less flowdependent was calculated with the continuity equation, based on the LV outflow tract (LVOT) and the velocity time integral (VTI), as follows:

$\mathrm{AVA}=($ cross-sectional area of LVOT $) *(\mathrm{VTI}$ of LVOT $) /($ VTI of the aortic valve)

Systolic function can be evaluated as the EF, based on volumetric measurements, as follows: EF (\%) = LVEDV - LVESV/LVEDV* 100; where LVEDV is the LV end-diastolic volume, and LVESV is the LV end-systolic volume. However, in studies I - IV, we used a four-degree scale to rate systolic function (i.e., normal, mildly abnormal, moderately abnormal, and severely abnormal), which corresponded to the EF categories recommended by Lang et al. ${ }^{91}$. At least two experienced observers performed this rating in each patient.

We calculated LV mass according to the Devereux formula, as follows:

LV mass $=0.8 \times\left\{1.04\left[(\text { LVEDD }+ \text { PWTd }+ \text { SWTd })^{3}-(\text { LVEDD })^{3}\right]\right\}+0.6 \mathrm{~g}$ 91. Where LVEDD is LV end diastolic dimension and PWTd is posterior wall thickness in end-diastole, SWTd is septal wall thickness in enddiastole.

In study IV, diastolic function was evaluated the day before surgery and at the six-month follow-up. Diastolic function was evaluated by measuring the mitral inflow, the isovolumetric relaxation time (IVRT), the pulmonary venous flow, the diastolic velocities of the myocardium, the systolic function, and left atrial size 93 . In study IV, we evaluated diastolic function primarily based on the ratio of the early mitral filling velocity (the Ewave) to the late diastolic filling velocity (the A-wave), i.e., the E/A ratio; 
the pulmonary venous systolic and diastolic flow velocities; the left atrial size, i.e., the left atrial end-systolic area in a four-chamber view, indexed to the body surface area; and the ratio of the E-wave to the early diastolic annular velocity (E/e'), where $\mathrm{e}^{\prime}$ is the mean of septal and lateral early diastolic annular velocities. For patients with contradictory or unclassifiable measurements, we took into consideration an individualized evaluation of the mitral flow deceleration time, the IVRT, and tricuspid regurgitation.

Diastolic function was graded into four categories: Normal diastolic function, Grade I (disturbed relaxation), Grade II (pseudonormalization), and Grade III (restrictive filling pattern). In the progression of diastolic dysfunction towards diastolic heart failure, elevated LV filling pressure is a late manifestation of diastolic dysfunction, 94 and disturbed relaxation is an early manifestation. Therefore, we classified the patients in study IV, based on whether they had elevated LV filling pressure. Patients with Grade I diastolic function were assigned to the low LV filling pressure group; patients with Grades II and III diastolic function were assigned to the high LV filling pressure group. The decision to divide the cohort into two groups was supported by the fact that the presence of Grade I diastolic dysfunction (impaired relaxation) did not appear to increase mortality, compared to normal diastolic function, in cardiac surgery ${ }^{86}$. In determination of the grade of diastolic dysfunction, it is emphasized in the most recent guideline to assess whether elevated left ventricular (LV) filling pressure is present or absent ${ }^{92}$.

Those authors also stressed the value of understanding the definition of the term 'LV filling pressure', because different LV and left atrium diastolic pressures are correlated with different Doppler signals 93 .

In the early manifestation of diastolic dysfunction, which is marked by abnormal relaxation (Grade I), the LV filling pressures measured as mean pulmonary capillary wedge pressure (PCWP) or mean left atrial pressure (LAP) are typically normal, but the left ventricular end-diastolic pressure 
(LVEDP) can be elevated during exercise. In later stages of diastolic dysfunction, or upon physical exertion, the PCWP and LAP rise. However, although the guidelines mentioned the fact that many echocardiographic variables assessed in the diastolic function evaluation are age-dependent, age was not included in their algorithms. Therefore, we used a guidelinebased automated algorithm (Fig.2) (https://liu.se/en/research/leftventricular-diastolic-function-decision-support), in which we included the age adjusted normal ranges for grading of diastolic function 95 .

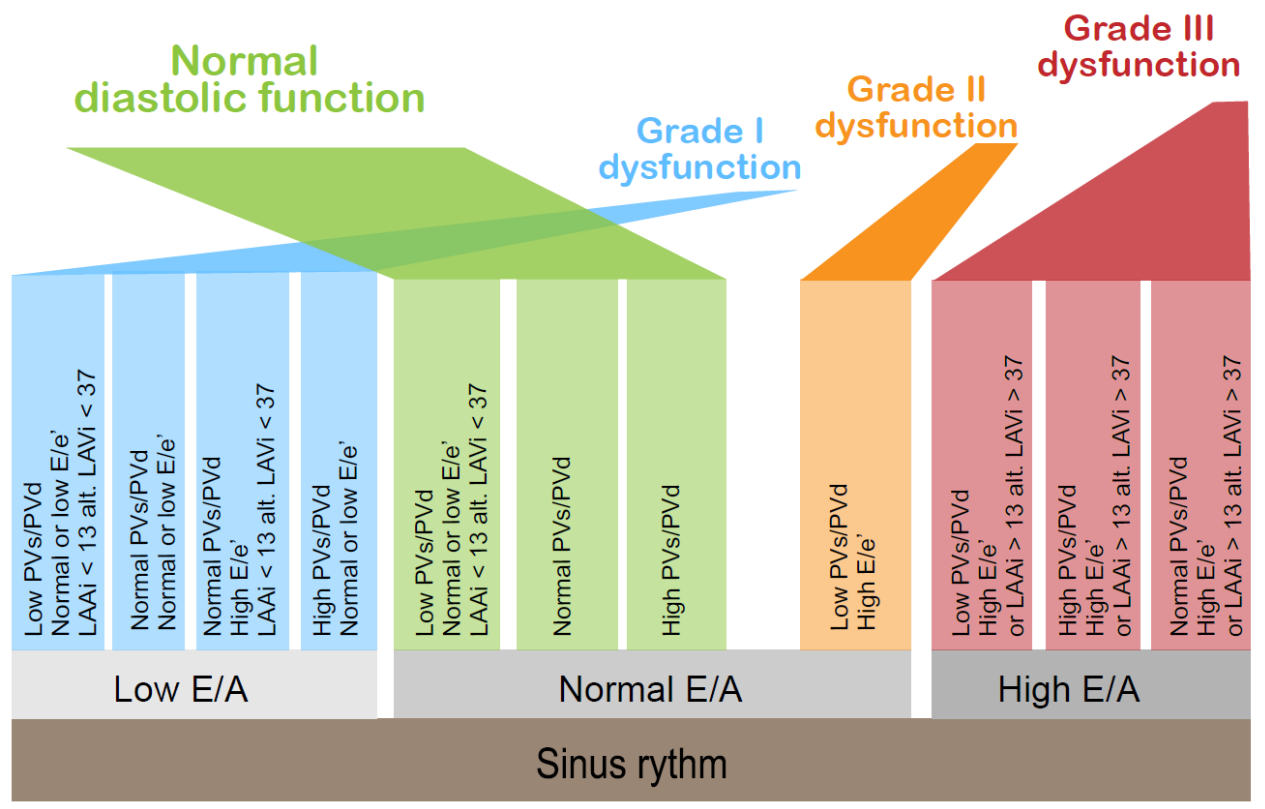

Figure 2. Assessment algorithm for standardized automated evaluation of LVDF. The assessment is based on E/A, PVS/PVd, E/e', LAAi or LAVi. The algorithm first compares these diastolic parameters to age-corrected normal values, and values are sorted into the categories "low", "normal", and "high". Thereafter, the categorized variables are entered into the analysis in hierarchical order for evaluation of $L V D F$, and the LVDF category is presented automatically. In the case of conflicting values or missing key variables, a request for manual assessment is presented. LVDF, left ventricular diastolic function. Reprinted with permission from Tamás and Nylander. 


\section{Clinical endpoints committee}

The Clinical Endpoints committee consisted of consultants in cardiothoracic surgery and cardiothoracic anesthesiology. Members reached a consensus decision, based on the prespecified criteria described above. The members were blinded to the results of NT-proBNP analyses, when they reached a consensus on whether a patient had experienced an episode of PHF or severe PHF. The committee reviewed all cases with suspected $\mathrm{PHF}$, based on $\mathrm{SvO} 2$ and systemic blood pressure, pulmonary artery pressure, central venous pressure, use of inotropic drugs or mechanical circulatory support, an extended ICU stay, or circulatory problems, reported by the anesthesiologists or surgeons in the clinical database. The committee decided whether a circulatory problem had occurred that met the prespecified criteria; whether a circulatory problem was severe; and when a circulatory problem was cardiac in origin, whether it was evident at weaning from the cardiopulmonary bypass or it became evident later in the postoperative course. The committee also decided whether any events leading to death were cardiac in origin. 


\section{DEFINITIONS}

\section{Postoperative heart failure}

PHF refers to heart failure during hospitalization in association with surgery. The definition of PHF differed slightly depending on nature of the studies, particularly depending on if they were retrospective or prospective. Details are given in respective paper.

In general PHF was defined as a hemodynamic state when the cardiac output does not meet the systemic demand without supportive measures other than correction of volume or vascular resistance 796 . This hemodynamic state was defined by mixed venous oxygen saturation ( $\mathrm{SvO} 2)$, which in contrast to cardiac output is well documented with regard to outcome 87, 96 97, 98. An empirically found approximate relationship between $\mathrm{SvO} 2$ and systolic arterial pressure (SAP) when using nitroprusside provided a guide for assessing the degree of inadequate circulation, as follows 99 : $\mathrm{SvO} 2<50 \%$ and $\mathrm{SAP}<130 \mathrm{mmHg}, \mathrm{SvO} 2<55 \%$ and $\mathrm{SAP}<110$ $\mathrm{mmHg}, \mathrm{SvO} 2<60 \%$ and $\mathrm{SAP}<90 \mathrm{mmHg}$ and $\mathrm{SvO} 2<65 \%$ and $\mathrm{SAP}<70$ $\mathrm{mmHg}$, excluding cases explained by shivering, anemia or hypovolemia.

Supportive measures consisted of inotropic treatment, an intra-aortic balloon pump (IAPB) for counter-pulsation, and/or metabolic support with glucose, insulin, potassium, and/or intravenous glutamate. The drugs, dosages (II-IV) or duration (I) required to be classified as inotropic treatment are specified in respective paper. 
In most cases, PHF was evident as an inability to wean from the cardiopulmonary bypass. The decision if PHF had occurred was determined by the consensus of an Endpoints committee, and the decision was based on available medical records and hemodynamic data.

Echocardiography was routinely used and supported pump failure or hypovolemia as cause for the inadequate hemodynamic state. CVP, PA pressures, urinary output and arterial blood gases were also routinely monitored.

Due to sample size in paper II we studied patients with PHF leading to extended ICU stays ( $\geq 72$ hours) or death due to hemodynamic problems requiring inotropes in prespecified dosages. This facilitated screening and identification of patients with heart failure postoperatively in a cohort including 2978 patients. 


\section{Statistics}

Baseline data are presented as the mean \pm SD or as the median with interquartile range (IQR), for continuous data, and as a proportion for categorical data. The Mann-Whitney U test was used to compare continuous data between two independent groups. The Kruskal-Wallis test was used to compare continuous data among more than two independent groups. To adjust for multiple comparisons of the mean ranks for all groups, we performed post hoc comparisons of the mean ranks of all pairs of groups ${ }^{100}$. For dichotomous data, a Chi-square test or Fisher's exact test was used for comparisons, as appropriate. For comparisons of more than two groups, a Bonferroni correction was performed. For repeated measures within groups, we performed a Wilcoxon signed rank test with the Bonferroni correction. A Pearson correlation analysis was performed, when appropriate. Skewed data, such as NT-proBNP levels, were transformed to $\log _{10}$ before performing linear regression analyses. Collinearity diagnostics with variance inflation factors were performed to exclude multicollinearity in multivariable linear regression analyses. To evaluate the prognostic performance of NT-proBNP with regard to mortality, PHF, and severe PHF, we performed ROC analyses. The best cut-off point for the area under the curve (AUC) was determined according to Youden's index. In model building, variables were selected, a priori, based on theoretical and clinical grounds, and they were held parsimoniously and controlled for to ensure that the assumption for each model was met. Multivariable logistic regression analyses were performed to identify pre- and perioperative risk factors for severe PHF and mortality (study II). Linear regression analyses were performed to explore variables associated with the rise in NTproBNP during an aortic intervention (study III).

Multivariable logistic regressions were used to explore variables associated with high LV filling pressure (study IV). Survival analyses were performed with the Kaplan-Meier method, and a log-rank test was performed 
to evaluate differences in survival between groups. Cox regression analyses were performed to explore variables associated with mortality. For study I, all statistical analyses were performed with Statistica 9.o (StatSoft Inc., Tulsa, USA). For study II, statistical analyses were performed with SPSS version 23 (IBM) for Windows and Statistica 13.2 (Dell Inc.). For study III, analyses were performed with the statistical package, Statistica V.10.o (StatSoft, Tulsa, Oklahoma, USA). For study IV, statistical analyses were performed with NCSS 12 Statistical Software, 2018 (NCSS, LLC, Kaysville, Utah, USA: ncss.com/software/ncss) and Statistica v. 13.2 (StatSoft, Tulsa, Oklahoma; USA).

\section{Ethics}

All studies were performed in accordance with the World Medical Association `s Helsinki declaration on ethical principles for medical research. The regional Ethics Review Board approved all studies. Approval numbers were: Dnr 03-364 for study I; Dnr 2011/ 497-31 for study II; and M 198-07, T 126-08, 2012/ 422-32 for studies III and IV. Patients in the prospective studies, study III and IV, were enrolled after providing written, informed consent. 


\section{RESULTS}

The main results from all four studies are summarized here. The detailed results can be pursued in the four papers compiled in this dissertation.

\section{Study I}

Study I was a retrospective examination of data on a cohort of patients that underwent surgery for isolated AS between January $1^{\text {st }} 1995$ and December $31^{\text {st }}$ 2000, focusing on PHF. The preoperative data are presented in Table 2.

Table 2. Preoperative data of patients with $(+)$ and without $(-)$ postoperative heart failure (PHF).

\begin{tabular}{|c|c|c|c|c|c|c|c|}
\hline & $\begin{array}{l}\text { All } \\
\text { patients } \\
(\mathrm{n}=397)\end{array}$ & $\begin{array}{l}\text { High risk } \\
\text { PHF - } \\
(n=48)\end{array}$ & $\begin{array}{l}\text { High risk } \\
\text { PHF + } \\
(n=21)\end{array}$ & $\mathrm{p}$-value & $\begin{array}{l}\text { Low risk } \\
\text { PHF - } \\
(n=304)\end{array}$ & $\begin{array}{l}\text { Low risk } \\
\text { PHF }+ \\
(n=24)\end{array}$ & p-value \\
\hline EuroSCORE & $5.7 \pm 2.2$ & $8.7 \pm 1.0$ & $9.7 \pm 1.5$ & 0.002 & $5.0 \pm 1.7$ & $5.1 \pm 1.9$ & 0.74 \\
\hline Log EuroSCORE & $5.7 \pm 4.8$ & $11.8 \pm 4.4$ & $17.1 \pm 9.5$ & $<0.001$ & $4.1 \pm 1.9$ & $4.5 \pm 2.1$ & 0.43 \\
\hline Age (years) & $70 \pm 10$ & $79 \pm 5$ & $78 \pm 4$ & 0.12 & $68 \pm 10$ & $68 \pm 11$ & 0.83 \\
\hline Female gender & $48 \%$ & $77 \%$ & $48 \%$ & 0.02 & $45 \%$ & $29 \%$ & 0.14 \\
\hline Body Mass Index & $26 \pm 4$ & $25 \pm 4$ & $26 \pm 4$ & 0.09 & $26 \pm 4$ & $27 \pm 4$ & 0.39 \\
\hline $\begin{array}{l}\text { Insulin or orally treated } \\
\text { DM }\end{array}$ & $11 \%$ & $13 \%$ & $29 \%$ & 0.17 & $10 \%$ & $13 \%$ & 0.72 \\
\hline Hypertension & $28 \%$ & $23 \%$ & $43 \%$ & 0.15 & $27 \%$ & $42 \%$ & 0.15 \\
\hline COPD & $9 \%$ & $17 \%$ & $24 \%$ & 0.75 & $7 \%$ & $8 \%$ & 0.67 \\
\hline P-Creatinine $(\mu \mathrm{mol} / \mathrm{L})$ & $100 \pm 26$ & $100 \pm 29$ & $105 \pm 25$ & 0.21 & $99 \pm 26$ & $108 \pm 16$ & 0.002 \\
\hline P-Creatinine $>167(\mu \mathrm{mol} / \mathrm{L})$ & $1 \%$ & $4 \%$ & $0 \%$ & 1.0 & $1 \%$ & $0 \%$ & 1.0 \\
\hline Stroke & $9 \%$ & $19 \%$ & $19 \%$ & 1.0 & $7 \%$ & $8 \%$ & 0.67 \\
\hline Peripheral artery disease & $3 \%$ & $9 \%$ & $5 \%$ & 1.0 & $1 \%$ & $4 \%$ & 0.32 \\
\hline Atrial fibrillation/flutter & $15 \%$ & $28 \%$ & $24 \%$ & 1.0 & $12 \%$ & $25 \%$ & 0.11 \\
\hline Angina pectoris & $23 \%$ & $35 \%$ & $5 \%$ & 0.007 & $23 \%$ & $17 \%$ & 0.62 \\
\hline Congestive heart failure & $37 \%$ & $46 \%$ & $90 \%$ & $<0.001$ & $30 \%$ & $50 \%$ & 0.06 \\
\hline NYHA class 1 or 2 & $43 \%$ & $19 \%$ & $0 \%$ & 0.05 & $51 \%$ & $29 \%$ & 0.04 \\
\hline NYHA class 3 or 4 & $57 \%$ & $81 \%$ & $100 \%$ & 0.05 & $49 \%$ & $71 \%$ & 0.04 \\
\hline Pulmonary hypertension & $3 \%$ & $6 \%$ & $33 \%$ & 0.007 & $1 \%$ & $0 \%$ & $<0.99$ \\
\hline Critical preoperative state & $2 \%$ & $2 \%$ & $24 \%$ & 0.009 & $0 \%$ & $4 \%$ & 0.14 \\
\hline $\begin{array}{l}\text { Aortic valve orifice area } \\
\left(\mathrm{cm}^{2}\right)\end{array}$ & $0.62 \pm 0.19$ & $0.56 \pm 0.16$ & $0.45 \pm 0.12$ & 0.014 & $0.63 \pm 0.19$ & $0.64 \pm 0.18$ & 0.68 \\
\hline
\end{tabular}

*Values are mean $\pm S D$. COPD: Chronic obstructive pulmonary disease; DM: Diabetes mellitus (insulin or orally treated).

In study I, we analyzed the relationship between PHF and mortality. In addition, we took into account the preoperative risk score, determined 
with the additive EuroSCORE. PHF occurred in 45 out of 397 (11\%) patients. The 30-day crude mortality was $6.7 \%$ in patients with PHF and $1.4 \%$ in patients without PHF ( $\mathrm{p}=0.05$ ). The five-year mortality was $42 \%$ in patients with PHF and $14 \%$ in patients without PHF ( $\mathrm{p}<0.001$; Table $3)$.

Table 3. Intraoperative and postoperative data of patients with (+) and without (-) postoperative heart failure (PHF).

\begin{tabular}{|c|c|c|c|c|c|c|c|}
\hline & $\begin{array}{l}\text { All } \\
\text { patients } \\
(\mathrm{n}=397)\end{array}$ & $\begin{array}{l}\text { High risk } \\
\text { PHF - } \\
(\mathrm{n}=48)\end{array}$ & $\begin{array}{l}\text { High risk } \\
\mathrm{PHF}+ \\
(\mathrm{n}=21)\end{array}$ & p-value & $\begin{array}{l}\text { Low risk } \\
\text { PHF - } \\
(n=304)\end{array}$ & $\begin{array}{l}\text { Low risk } \\
\mathrm{PHF}+ \\
(\mathrm{n}=24)\end{array}$ & p-value \\
\hline Elective operation & $92 \%$ & $85 \%$ & $52 \%$ & 0.006 & $96 \%$ & $92 \%$ & 0.3 \\
\hline Urgent operation & $7 \%$ & $13 \%$ & $38 \%$ & 0.02 & $4 \%$ & $8 \%$ & 0.3 \\
\hline Emergency operation & $1 \%$ & $2 \%$ & $10 \%$ & 0.22 & $0 \%$ & $0 \%$ & $>0.99$ \\
\hline Cross-clamp time (minutes) & $81 \pm 21$ & $74 \pm 17$ & $86 \pm 25$ & 0.04 & $80 \pm 19$ & $102 \pm 33$ & $<0.001$ \\
\hline CPB time (minutes) & $106 \pm 27$ & $98 \pm 21$ & $119 \pm 30$ & 0.002 & $103 \pm 22$ & $147 \pm 47$ & $<0.001$ \\
\hline Biological prostheses & $61 \%$ & $92 \%$ & $95 \%$ & $>0.99$ & $55 \%$ & $56 \%$ & $>0.99$ \\
\hline Valve size $19 \mathrm{~mm}$ & $12 \%$ & $27 \%$ & $10 \%$ & 0.13 & $10 \%$ & $4.0 \%$ & 0.71 \\
\hline EOA Index $<0.75$ & $32 \%$ & $44 \%$ & $67 \%$ & 0.12 & $28 \%$ & $25 \%$ & 0.82 \\
\hline Inotropic treatment & $3 \%$ & $0 \%$ & $95 \%$ & 0.001 & $38 \%$ & $92 \%$ & $<0.001$ \\
\hline Metabolic treatment & $7 \%$ & $7 \%$ & $52 \%$ & 0.001 & $2 \%$ & $33 \%$ & $<0.001$ \\
\hline IABP & $0.3 \%$ & $0 \%$ & $5 \%$ & 0.30 & $0 \%$ & $0 \%$ & $>0.99$ \\
\hline Atrial flutter/fibrillation & $34 \%$ & $34 \%$ & $38 \%$ & 0.79 & $33 \%$ & $33 \%$ & $>0.99$ \\
\hline Erythrocyte transfusion & $37 \%$ & $58 \%$ & $71 \%$ & 0.42 & $30 \%$ & $50 \%$ & 0.06 \\
\hline Thrombocyte transfusion & $8 \%$ & $12 \%$ & $24 \%$ & 0.52 & $6 \%$ & $12 \%$ & 0.19 \\
\hline $\begin{array}{l}\text { P-Creatinine maximum } \\
(\mu \mathrm{mol} / \mathrm{L})\end{array}$ & $105 \pm 46$ & $105 \pm 40$ & $140 \pm 81$ & 0.06 & $100 \pm 35$ & $134 \pm 97$ & 0.001 \\
\hline P-Creatinine $\geq 50 \%$ & $5 \%$ & $4 \%$ & $29 \%$ & 0.01 & $3 \%$ & $13 \%$ & 0.04 \\
\hline Dialysis & $1 \%$ & $0 \%$ & $0 \%$ & $>0.99$ & $0 \%$ & $8 \%$ & 0.005 \\
\hline Myocardial infarction & $3 \%$ & $2 \%$ & $14 \%$ & 0.08 & $1 \%$ & $13 \%$ & 0.01 \\
\hline Stroke & $4 \%$ & $6 \%$ & $5 \%$ & $>0.99$ & $3 \%$ & $8 \%$ & 0.22 \\
\hline Bleeding/reoperation & $5 \%$ & $10 \%$ & $14 \%$ & 0.69 & $3 \%$ & $8 \%$ & 0.22 \\
\hline $\begin{array}{l}\text { Deep sternal wound in- } \\
\text { fection }\end{array}$ & $1 \%$ & $2 \%$ & $0 \%$ & $>0.99$ & $1 \%$ & $0 \%$ & $>0.99$ \\
\hline Time on ventilator (hours) & $11 \pm 29$ & $8 \pm 11$ & $30 \pm 40$ & 0.003 & $7 \pm 9$ & $46 \pm 99$ & $<0.001$ \\
\hline ICU stay (days) & $1.4 \pm 1.6$ & $1.4 \pm 1.1$ & $3.0 \pm 3.1$ & 0.08 & $1.1 \pm 0.6$ & $3.5 \pm 4.4$ & $<0.001$ \\
\hline Hospital stay (days) & $8 \pm 4$ & $9 \pm 6$ & $10 \pm 5$ & 0.77 & $9 \pm 3$ & $11 \pm 5$ & 0.03 \\
\hline 30-day mortality & $2.0 \%$ & $2.1 \%$ & $9.5 \%$ & 0.22 & $1.3 \%$ & $4.2 \%$ & 0.32 \\
\hline 5-year mortality & $17 \%$ & $36 \%$ & $43 \%$ & 0.60 & $11 \%$ & $42 \%$ & $<0.001$ \\
\hline
\end{tabular}

*Values are mean $\pm S D . C P B$ : Cardiopulmonary bypass; EOA: Effective orifice area; IABP: Intra-aortic balloon pump; ICU: Intensive care unit; P-Creatinine $\geq 50 \%$ : Proportion of patients with postoperative P-Creatinine exceeding the preoperative value by $50 \%$.

Patients at high risk (EuroSCORE $>7 ; n=69$ ) had a 30-day mortality of $4.3 \%$. In comparison, patients at low risk (EuroSCORE $\leq 7 ; n=328$ ) had a 30-day mortality of $1.5 \%(\mathrm{p}=0.15)$. The crude five-year mortality was $42 \%$ in patients at low risk with $\mathrm{PHF}$, compared to $11 \%$ in patients at low risk 
without PHF ( $\mathrm{p}<0.001)$. Among patients at high risk, mortality rates were not significantly different between those with and those without PHF ( $p=0.60$; Fig. 3).

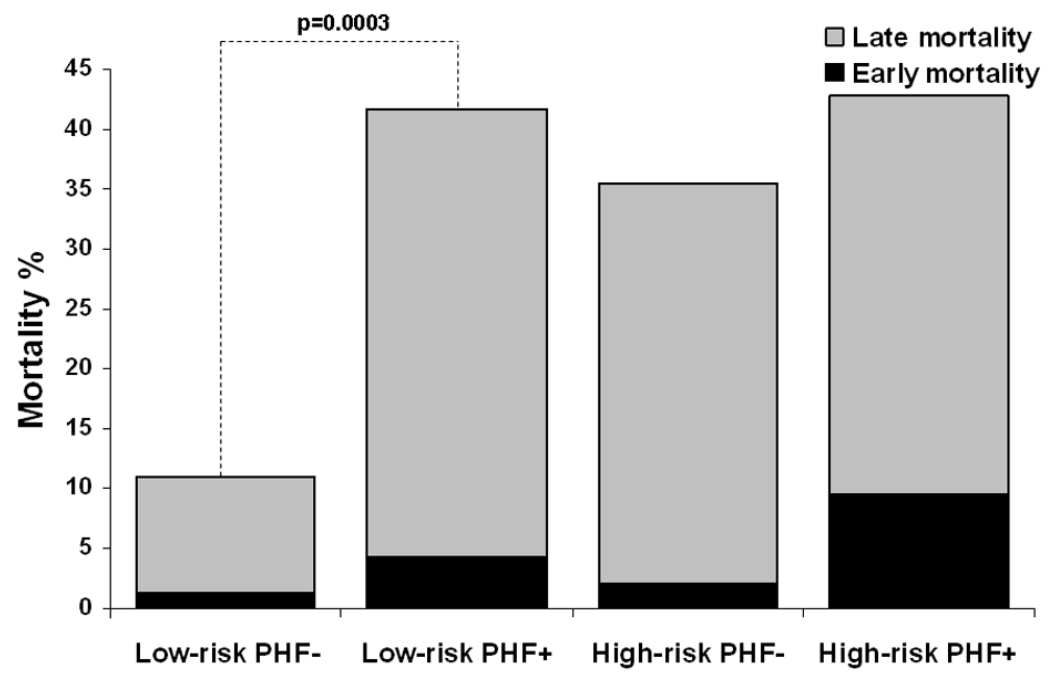

Figure 3: Mortality in low-risk (additive EuroSCORE $\leq 7$ ) and high-risk (additive EuroSCORE > 7) groups with (+) and without (-) postoperative heart failure (PHF). Early mortality is 30-day mortality' late mortality is mortality from 30 days to five years postoperatively. 


\section{Study II}

In study II, we investigated the influence of the underlying heart disease, per se, on preoperative NT-proBNP levels. We evaluated an unselected cohort of patients that underwent a first-time surgery, from April 2010 to August 2016, for coronary artery disease (CAD; $n=2226)$, AS $(n=406)$, or mitral regurgitation (MR; $n=346)$. We also evaluated the relationships between NT-proBNP and severe PHF and short-term postoperative mortality. The patient selection process is presented in Figure 4. The characteristics of all patients and subgroups are presented in Table 4.

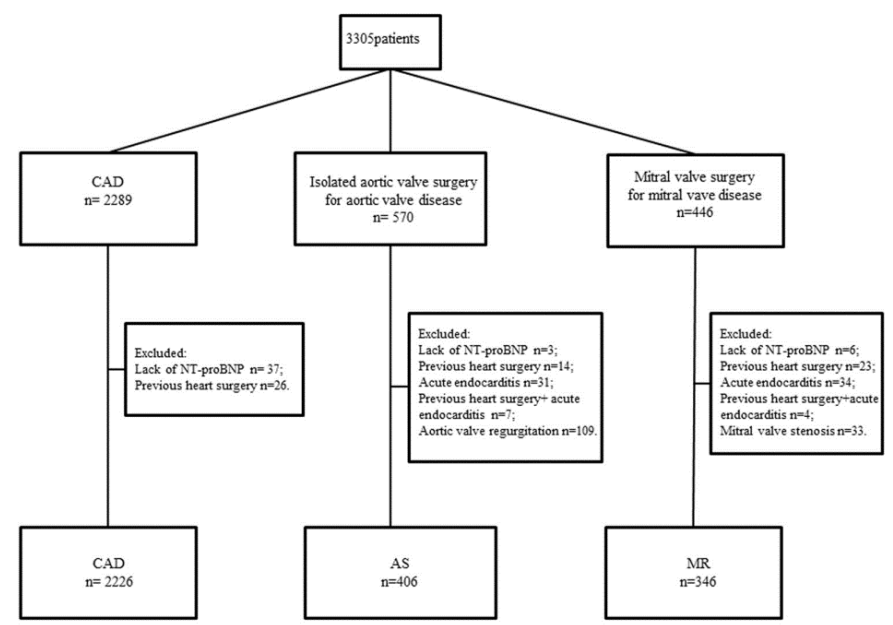

Figure 4. Patient flow chart. CAD: patients with coronary artery disease admitted for first time $C A B G, A S$ : patients with aortic stenosis without significant aortic regurgitation admitted for first time aortic valve replacement, MR: patients with mitral regurgitation without significant mitral stenosis admitted for first time mitral valve surgery with or without tricuspid valve procedure. A total of 161 patients underwent mitral valve surgery with tricuspid valve procedure, and, 102 patients had concomitant Maze procedure (26 patients undergoing CABG, 12 undergoing isolated aortic valve surgery, and 64 undergoing mitral valve surgery). 
Table 4. Demographic data in all patients and subgroups.

\begin{tabular}{|c|c|c|c|c|c|c|c|c|}
\hline & $\begin{array}{l}\text { All patients } \\
(\mathrm{n}=2978)\end{array}$ & CAD $(n=2226)$ & $\begin{array}{c}\mathrm{AS} \\
(\mathrm{n}=406)\end{array}$ & $\operatorname{MR}(n=346)$ & p* & $\mathrm{p}^{\dagger}$ & $\mathrm{p}^{*}$ & $\mathrm{p}^{\S}$ \\
\hline Age (years) & $70[63-76]$ & $69[63-75]$ & $73[66-78]$ & $67[58-74]$ & $<0.001$ & $<0.001$ & $<0.001$ & $<0.001$ \\
\hline Female gender & $24 \%(714)$ & $18 \%(410)$ & $50 \%(202)$ & $29 \%(102)$ & $<0.001$ & $<0.001$ & $<0.001$ & $<0.001$ \\
\hline Preop-NT-proBNP (ng/L) & $330[130-970]$ & $290[120-833]$ & $595[260-1510]$ & $400[110-1350]$ & $<0.001$ & $<0.001$ & 0.050 & $<0.001$ \\
\hline BMI $\mathrm{kg} / \mathrm{m}^{2}$ & $27[24-30]$ & $27[25-30]$ & $27[24-31]$ & $25[23-28]$ & $<0.001$ & $>0.99$ & $<0.001$ & $<0.001$ \\
\hline $\begin{array}{l}\text { Obesity } \\
\left(\text { BMI }>30 \mathrm{~kg} / \mathrm{m}^{2}\right)\end{array}$ & $26 \%(782)$ & $27 \%(606)$ & $32 \%(130)$ & $13 \%(46)$ & $<0.001$ & 0.051 & $<0.001$ & $<0.001$ \\
\hline BSA m ${ }^{2}$ & $1.96[1.83-2.09]$ & $1.98[1.85-2.10]$ & $1.90[1.77-2.05]$ & $1.93[1.80-2.06]$ & $<0.001$ & $<0.001$ & $<0.001$ & 0.58 \\
\hline $\begin{array}{l}\text { Preop hemoglobin } \\
\mathrm{g} / \mathrm{L}\end{array}$ & $141[132-150]$ & $141[132-150]$ & $140[130-148]$ & $142[133-149]$ & 0.024 & 0.025 & $>0.99$ & 0.08 \\
\hline $\begin{array}{l}\text { Preop p-creatinine } \\
\mu \mathrm{mol} / \mathrm{L}\end{array}$ & 85 [74-101] & 86 [74-102] & 80 [68-97] & 83 [73-98] & $<0.001$ & $<0.001$ & 0.07 & 0.11 \\
\hline $\begin{array}{l}\text { Preop-eGFR } \mathrm{mL} \cdot \mathrm{min}^{-1} \\
\cdot 1.73 \mathrm{~m}^{-2}\end{array}$ & $73[60-86]$ & $73[60-86]$ & $72[58-86]$ & $75[62-87]$ & 0.29 & & & \\
\hline Preop p-albumin g/L & 39 [36-42] & $39[36-42]$ & $40[37-42]$ & $40[38-43]$ & $<0.001$ & $<0.001$ & $<0.001$ & $>0.99$ \\
\hline Smoker & $11 \%(336)$ & $13 \%(299)$ & $5 \%(22)$ & $4 \%(15)$ & $<0.001$ & $<0.001$ & $<0.001$ & 0.50 \\
\hline Diabetes & $25 \%(739)$ & $29 \%(655)$ & $17 \%(67)$ & $5 \%(17)$ & $<0.001$ & $<0.001$ & $<0.001$ & $<0.001$ \\
\hline Hypertension & $65 \%(1934)$ & $70 \%(1558)$ & $59 \%(240)$ & $39 \%(136)$ & $<0.001$ & $<0.001$ & $<0.001$ & $<0.001$ \\
\hline COPD & $7 \%(219)$ & $8 \%(173)$ & $6 \%(23)$ & $7 \%(23)$ & 0.28 & & & \\
\hline Cerebrovascular disease & $7 \%(208)$ & $8 \%(167)$ & $5 \%(19)$ & $6 \%(22)$ & 0.28 & & & \\
\hline $\begin{array}{l}\text { Extracardiac arterial } \\
\text { disease }\end{array}$ & $7 \%(208)$ & $8 \%(187)$ & $4 \%(15)$ & $2 \%(6)$ & $<0.001$ & 0.001 & $<0.001$ & 0.10 \\
\hline Previous vascular surgery & $4 \%(115)$ & $5 \%(101)$ & $2 \%(9)$ & $1 \%(5)$ & 0.004 & 0.031 & 0.007 & 0.44 \\
\hline Preop dialysis & $0.8 \%(25)$ & $0.8 \%(18)$ & $1.3 \%(5)$ & $0.6 \%(2)$ & 0.59 & & & \\
\hline Angina & $74 \%(2207)$ & $97 \%(2151)$ & $14 \%(56)$ & 0 & $<0.001$ & $<0.001$ & $<0.001$ & $<0.001$ \\
\hline Unstable angina & $46 \%(1372)$ & $62 \%(1372)$ & 0 & 0 & $<0.001$ & $<0.001$ & $<0.001$ & - \\
\hline CCS IV & $9 \%(271)$ & $12 \%(271)$ & 0 & 0 & $<0.001$ & $<0.001$ & $<0.001$ & - \\
\hline $\begin{array}{l}\text { Recent myocardial infar- } \\
\text { ction }(<3 \text { weeks })\end{array}$ & $28 \%(839)$ & $38 \%(835)$ & $0.7 \%(3)$ & $0.3 \%(1)$ & $<0.001$ & $<0.001$ & $<0.001$ & 0.40 \\
\hline $\begin{array}{l}\text { Moderate or severe LV } \\
\text { dysfunction }\end{array}$ & $17 \%(501)$ & $19 \%(415)$ & $12 \%(49)$ & $11 \%(37)$ & $<0.001$ & 0.001 & $<0.001$ & 0.56 \\
\hline Severe LV dysfunction & $4 \%(134)$ & $5 \%(121)$ & $2 \%(10)$ & $0.9 \%$ & $<0.001$ & 0.011 & $<0.001$ & 0.09 \\
\hline $\begin{array}{l}\text { Preop pulmonary hyper- } \\
\text { tension }\end{array}$ & $3 \%(81)$ & $1 \%(21)$ & $2 \%(9)$ & $15 \%(51)$ & $<0.001$ & 0.028 & $<0.001$ & $<0.001$ \\
\hline NYHA III or IV & $58 \%(1718)$ & $62 \%(1374)$ & $50 \%(203)$ & $41 \%(141)$ & $<0.001$ & $<0.001$ & $<0.001$ & 0.011 \\
\hline NYHA IV & $8 \%(239)$ & $9 \%(209)$ & $1 \%(4)$ & $8 \%(26)$ & $<0.001$ & $<0.001$ & 0.26 & $<0.001$ \\
\hline Preop CHF & $17 \%(506)$ & $14 \%(306)$ & $15 \%(62)$ & $40 \%(138)$ & $<0.001$ & 0.42 & $<0.001$ & $<0.001$ \\
\hline Preop atrial fibrillation & $6 \%(187)$ & $3 \%(76)$ & $8 \%(31)$ & $23 \%(80)$ & $<0.001$ & $<0.001$ & $<0.001$ & $<0.001$ \\
\hline Additive EuroSCORE & $4[3-6]$ & $4[2-6]$ & $6[4-7]$ & $5[3-7]$ & $<0.001$ & $<0.001$ & $<0.001$ & 0.07 \\
\hline
\end{tabular}

Data given as medians [interquartile range] or percentages (number). * between three groups, ${ }^{\dagger} C A D$ vs $A S,{ }^{\ddagger} C A D$ vs $M R, \S A S$ vs MR. AS: aortic stenosis, BMI: body mass index, CAD: coronary artery disease, COPD: chronic obstructive pulmonary disease, eGFR: estimated glomerular filtration rate according to MDRD formula, $L V$ : left ventricular, MR: mitral regurgitation, NYHA: New York Heart Association functional classification, CHF: congestive heart failure, EuroSCORE: European system for cardiac operative risk evaluation.

Severe PHF occurred in 130 out of 2978 (4\%) patients. After adjusting for known confounders of NT-proBNP (i.e., age, female sex, renal function, and obesity), the mean preoperative NT-proBNP levels in patients with 
AS and MR, respectively, were 1.7-fold $(\mathrm{p}<0.001)$ and 1.4-fold $(\mathrm{p}<0.001)$ higher than in patients with CAD (Table 5).

Table 5. Multivariable linear regression for $\log _{10}$ NT-proBNP

\begin{tabular}{llll}
\hline & Adjusted coefficient* & $\mathbf{9 5 \% C l}$ & $\mathbf{p}$ \\
\hline Age (years) & 0.020 & $0.018-0.022$ & $<0.001$ \\
Preop eGFR $\left(\mathrm{mL} \cdot \mathrm{min}^{-1} \bullet 1.73 \mathrm{~m}^{-2}\right)$ & -0.006 & $-0.007--0.005$ & $<0.001$ \\
Male & ref & & \\
Female & 0.114 & $0.064-0.164$ & $<0.001$ \\
CAD & ref & & \\
MR & 0.150 & $0.085-0.215$ & $<0.001$ \\
AS & 0.223 & $0.160-0.285$ & $<0.001$ \\
\hline
\end{tabular}

Adjusted $R^{2}=0.215$, ANOVA for the model $(d f=5, F=164.162, p<0.0001)$ eGFR: estimated glomerular filtration rate according to MDRD formula, CAD: coronary artery disease, AS: aortic valve stenosis, MR: mitral valve regurgitation.

Patients that developed severe PHF had significantly higher preoperative levels of NT-proBNP compared to those without severe PHF (Table 6).

Table 6. Preoperative NT-proBNP in Patients with or without SPHF and postoperative mortality.

\begin{tabular}{lllllll}
\hline & & SPHF & & \multicolumn{3}{c}{ Postoperative mortality } \\
& Yes & No & p & Yes & No & p \\
\hline All & $2060[753-4910]$ & $310[120-910]$ & $<0.001$ & $1780[430-3200]$ & $320[130-958]$ & $<0.001$ \\
CAD & $2345[655-5810]$ & $280[110-750]$ & $<0.001$ & $1810[440-3260]$ & $280[120-800]$ & $<0.001$ \\
AS & $1290[563-4018]$ & $585[250-1498]$ & 0.047 & $2835[230-10090]$ & $595[260-1510]$ & 0.53 \\
MR & $1650[925-3802]$ & $345[97-1115]$ & $<0.001$ & $1245[430-2640]$ & $395[110-1280]$ & 0.08 \\
\hline
\end{tabular}

Preoperative NT-proBNP $(n g / L)$ given as medians [interquartile range]. SPHF: severe postoperative heart failure, All: all patients, CAD: coronary artery disease, AS: aortic valve stenosis, MR: mitral valve regurgitation. 
For patients with CAD and MR, the ROC AUCs showed that preoperative NT-proBNP could discriminate well between patients who did and those who did not develop severe PHF (Fig. 5).

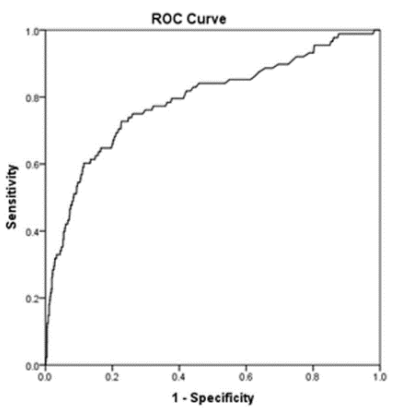

A

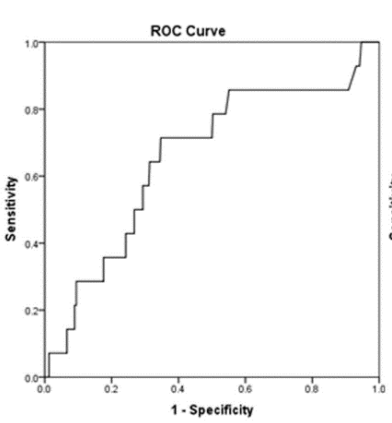

B

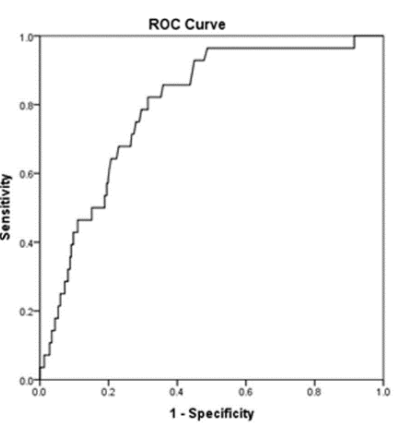

$\mathrm{C}$

Figure 5. Discrimination of preoperative NT-proBNP with regard to SPHF in patients with CAD, AS, and MR. Preoperative NT-proBNP demonstrated significant discrimination according to ROC analysis with regard to SPHF in patients with CAD (A: AUC =0.79, 95\% CI 0.73-0.85, $p<0.0001$; best cutoff $855 \mathrm{ng} / \mathrm{L}$ with a sensitivity of $73 \%$ and a specificity of $77 \%$ ), $A S$ (B: AUC $=0.66$, 95\% CI 0.51-0.81, $p=0.047$; best cutoff $975 \mathrm{ng} / \mathrm{L}$ with a sensitivity of $71 \%$ and specificity of 65\%), and MR (C: AUC $=0.80,95 \%$ CI 0.72-0.87, $p<0.0001$; best cutoff $800 \mathrm{ng} / \mathrm{L}$ with a sensitivity of $82 \%$ and specificity of $69 \%)$. ROC: receiver operating characteristics, SPHF: severe postoperative heart failure, AUC: area under the curve, CI: confidence interval.

No significant difference in postoperative mortality was found between groups (Table 7). 
Table 7. Intra- and postoperative characteristics in all patients and subgroups.

\begin{tabular}{|c|c|c|c|c|c|c|c|c|}
\hline & $\begin{array}{l}\text { All patients } \\
(n=2978)\end{array}$ & $\begin{array}{l}\text { CAD } \\
(n=2226)\end{array}$ & $\begin{array}{l}\text { AS } \\
(n=406)\end{array}$ & $M R(n=346)$ & p* & $\mathbf{p}^{+}$ & $\mathbf{p}^{\ddagger}$ & $\mathbf{p}^{\S}$ \\
\hline $\begin{array}{l}\text { Critical preoperative } \\
\text { state }\end{array}$ & $1 \%(30)$ & $1 \%(19)$ & $0.5 \%(2)$ & $3 \%(9)$ & 0.005 & 0.76 & 0.004 & 0.016 \\
\hline $\begin{array}{l}\text { Aortic cross- clamp } \\
\text { time (minutes) }\end{array}$ & $56[44-70]$ & $51[40-62]$ & $65[56-75]$ & $92[76-116]$ & $<0.001$ & $<0.001$ & $<0.001$ & $<0.001$ \\
\hline ICU stay (hours) & 21 [18-23] & $21[17-23]$ & $22[18-23]$ & 21 [20-23] & $<0.001$ & 0.048 & $<0.001$ & 0.44 \\
\hline $\begin{array}{l}\text { ICU stay } \\
>72 \text { hours }\end{array}$ & $6 \%(192)$ & $6 \%(133)$ & $6 \%(26)$ & $10 \%(33)$ & 0.043 & 0.74 & 0.012 & 0.11 \\
\hline Severe PHF & $4 \%(130)$ & $4 \%(88)$ & $3 \%(14)$ & $8 \%(28)$ & 0.001 & 0.63 & 0.001 & 0.006 \\
\hline $\begin{array}{l}\text { Postoperative } \\
\text { stroke }\end{array}$ & $0.7 \%(22)$ & $0.9 \%(19)$ & $0.5 \%(2)$ & $0.3 \%(1)$ & 0.43 & & & \\
\hline CK-MB POD1 ( $\mu \mathrm{g} / \mathrm{L})$ & $16[10-28]$ & 14 [9-23] & $16[12-23]$ & $40[26-68]$ & $<0.001$ & $<0.001$ & $<0.001$ & $<0.001$ \\
\hline CK-MB POD1 & $12 \%(345)$ & $9 \%(202)$ & $5 \%(22)$ & $35 \%(121)$ & $<0.001$ & 0.012 & $<0.001$ & $<0.001$ \\
\hline$>50 \mu \mathrm{g} / \mathrm{L}$ & & & & & & & & \\
\hline $\begin{array}{l}\text { Creatinine elevation } \\
\geq 50 \%\end{array}$ & $9 \%(262)$ & $8 \%(186)$ & $11 \%(46)$ & $9 \%(30)$ & 0.16 & & & \\
\hline $\begin{array}{l}\text { Postoperative } \\
\text { mortality }\end{array}$ & $2 \%(53)$ & $2 \%(43)$ & $1 \%(4)$ & $2 \%(6)$ & 0.41 & & & \\
\hline
\end{tabular}

Data given as medians [interquartile range] or percentages (number). * between three groups, ${ }^{\dagger} C A D$ vs $A S,{ }^{\ddagger} C A D$ vs $M R,{ }^{\S} A S$ vs MR. AS: aortic stenosis, CAD: coronary artery disease, CPB: cardiopulmonary bypass, CK-MB: creatine kinase-MB isoenzyme, ICU: intensive care unit, MR: mitral regurgitation, POD1: first postoperative day, PHF: postoperative heart failure. 
The ROC curve for patients with CAD indicated that NT-proBNP had good predictive power for 30-day mortality (Fig. 6).

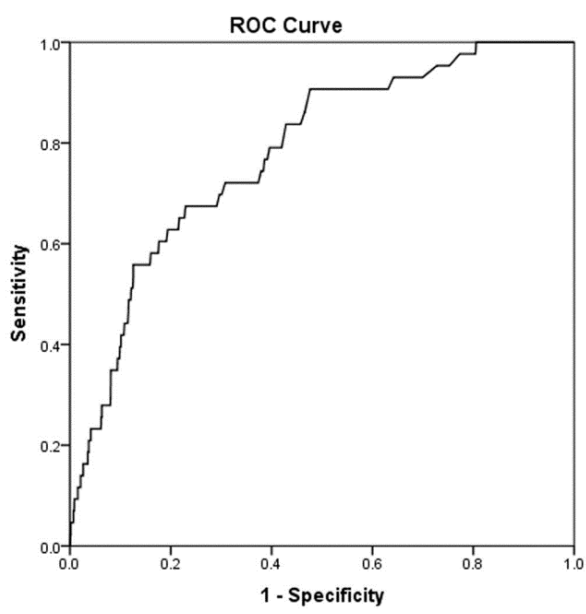

Figure 6. Discrimination of preoperative NT-proBNP with regard to postoperative mortality in patients with CAD. ROC analysis demonstrated an AUC of 0.78 (95\% CI 0.71-0.85, $p<0.001$; best cutoff $905 \mathrm{ng} / \mathrm{L}$ with a sensitivity of $67 \%$ and specificity of 77\%). ROC: receiver operating characteristics, AUC: area under the curve, CI: confidence interval.

\section{Study III}

In a prospective, longitudinal, observational study, between June 2008 and January 2013, we investigated the dynamics of NT-proBNP and related them to one-year mortality in patients that underwent either SAVR or TAVI. The preoperative and postoperative characteristics are given in Table 8. 


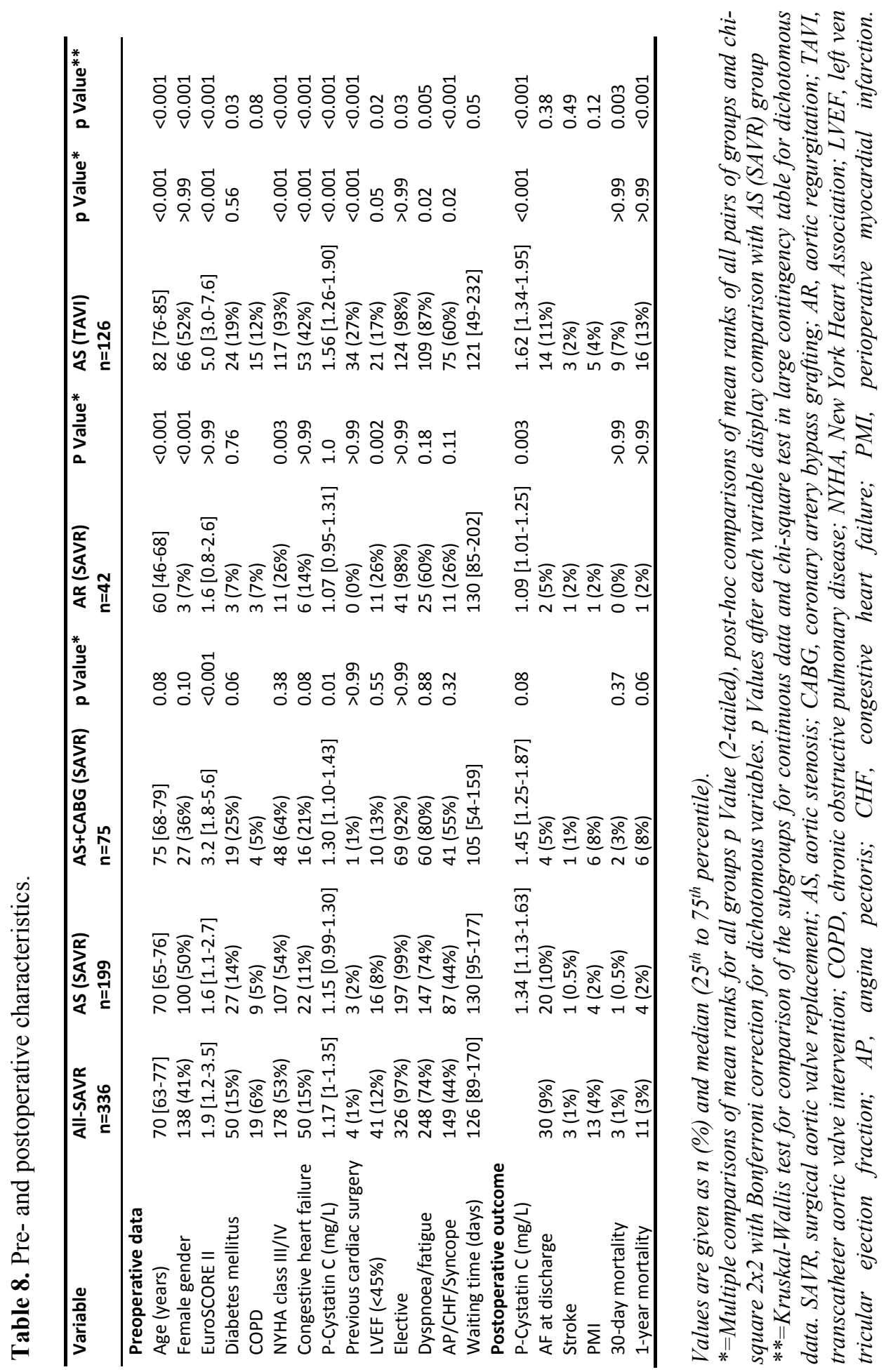


We observed a statistically significant increase in NT-proBNP, which was elicited by the aortic valve intervention (Fig. 7).
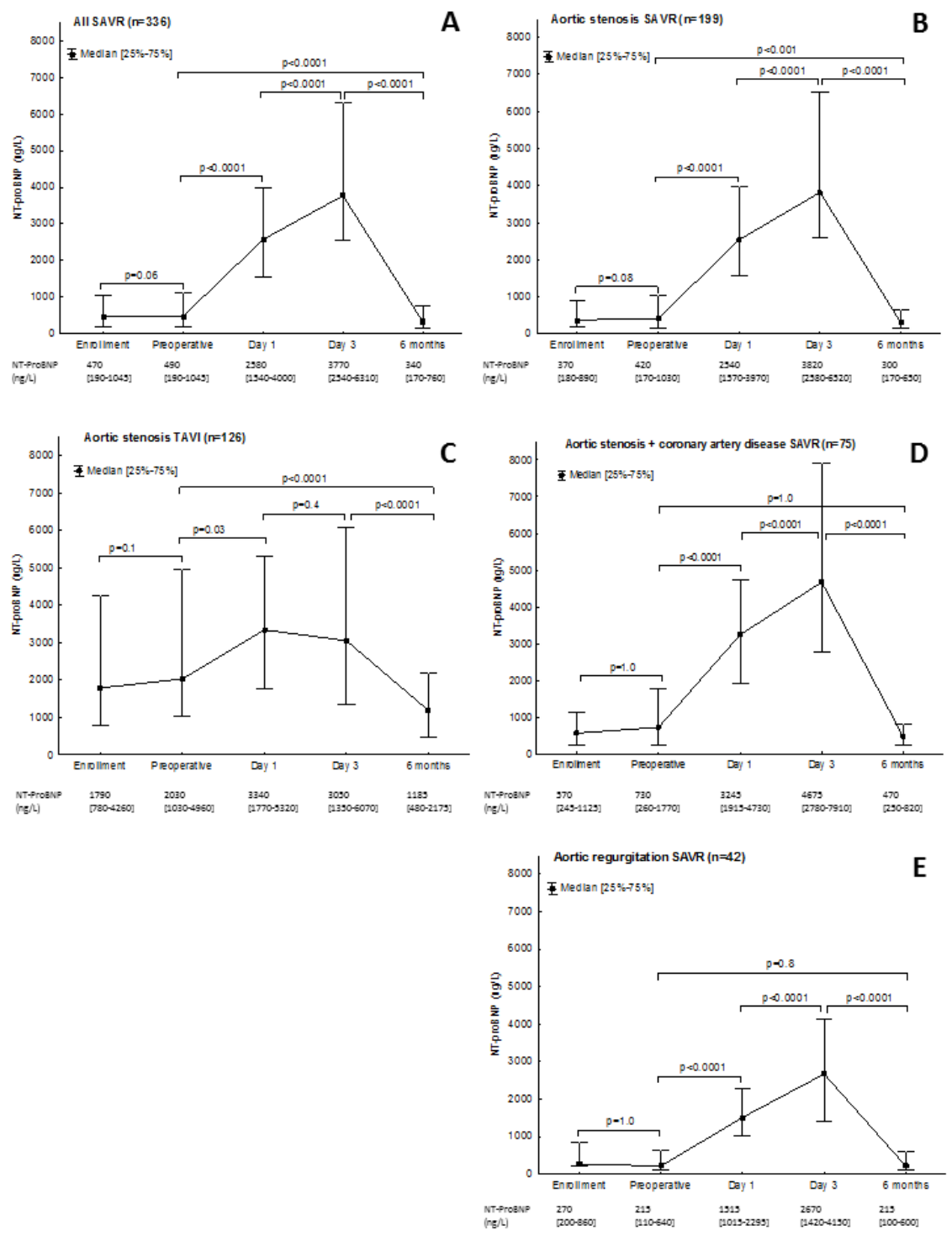

Figure 7. The NT-proBNP levels for surgical aortic valve replacement (SAVR) patients $(A)$, transcatheter aortic valve replacement (TAVI) patients $(C)$, and for the three large subgroups of $S A V R$ patient based on cardiac pathology $(B, D$, and $E)$. Data are shown as median and $25^{\text {th }}$ to $75^{\text {th }}$ percentile. Wilcoxon signed rank test with Bonferroni correction was used for repeated comparisons within groups. 
Among patients that underwent SAVR, NT-proBNP levels peaked on the third postoperative day. In comparison, patients that underwent TAVI showed a NTproBNP peak on the first postoperative day. Despite a median waiting time of four months from the preoperative evaluation to the intervention, we observed no increase in NT-proBNP levels. At the six-month postoperative follow-up, the levels of NT-proBNP had fallen to or below preoperative values in all patients. In patients that underwent SAVR, both the preoperative and early postoperative NT-proBNP values were associated with one-year mortality, but this association was not observed for patients that underwent TAVI (Table 9, 10).

Table 9. NT-proBNP (ng/L) values measured before and after surgery in relation to 1year mortality.

\begin{tabular}{lllll}
\hline & All & Dead & Survivors & $p$ Value \\
\hline All-SAVR $\mathbf{n = 3 3 6}$ & & $\mathrm{n}=11(3 \%)$ & $\mathrm{n}=325(97 \%)$ & \\
Preoperative & $490[180-1120]$ & $1250[960-3580]$ & $460[170-1090]$ & $<0.001$ \\
Postoperative day-1 & $2580[1540-4000]$ & $4770[2680-13600]$ & $2550[1540-3840]$ & 0.02 \\
Postoperative day-3 & $3770[2540-6310]$ & $9480[4880-12300]$ & $3730[2460-6130]$ & $<0.001$ \\
AS (SAVR) $\mathbf{n = 1 9 9}$ & & $\mathrm{n}=4(2 \%)$ & $\mathrm{n}=195(98 \%)$ & \\
Preoperative & $430[170-1030]$ & $2415[1120-7790]$ & $410[170-990]$ & 0.01 \\
Postoperative day-1 & $2545[1575-3940]$ & $1535[4410-9450]$ & $2530[1565-3840]$ & 0.01 \\
Postoperative day-3 & $3800[2580-6520]$ & $7820[6030-10830]$ & $3750[2580-6210]$ & 0.03 \\
AS+CABG (SAVR) $\mathbf{n = 7 5}$ & & $\mathrm{n}=6(8 \%)$ & $\mathrm{n}=69(92 \%)$ & \\
Preoperative & $730[260-1770]$ & $1185[960-2600]$ & $720[230-1770]$ & 0.04 \\
Postoperative day-1 & $3245[1915-4730]$ & $4770[2680-14000]$ & $3220[1890-4630]$ & 0.26 \\
Postoperative day-3 & $4675[2780-7910]$ & $11700[10500-12300]$ & $4350[2760-7110]$ & 0.04 \\
AS (TAVI) $\mathbf{n = 1 2 6}$ & & $\mathrm{n}=16(13 \%)$ & $\mathrm{n}=110(87 \%)$ & \\
Preoperative & $2030[1030-4960]$ & $2525[1465-4260]$ & $1990[920-5120]$ & 0.87 \\
Postoperative day-1 & $3440[1770-5320]$ & $4780[1950-5750]$ & $3325[1710-5220]$ & 0.25 \\
Postoperative day-3 & $3050[1350-6070]$ & $4840[3260-10900]$ & $2615[1345-5595]$ & 0.10 \\
\hline
\end{tabular}

Values are given as median [25th to $75^{\text {th }}$ ] percentile. NT-proBNP, $N$-terminal pro-B-type natriuretic peptide; SAVR, surgical aortic valve replacement; $A S$, aortic stenosis; $C A B G$, coronary artery bypass grafting; AR, aortic regurgitation; TAVI, transcatheter aortic valve intervention. 
Table 10. ROC analysis with AUC for NT-proBNP and 1-year mortality

\begin{tabular}{llll}
\hline & Preoperative & Postoperative day 1 & Postoperative day 3 \\
\hline All-SAVR & & & \\
AUC [95 \% CI] & $0.79[0.71-0.88]$ & $0.71[0.52-0.89]$ & $0.79[0.61-0.94]$ \\
$p$ Value & 0.001 & 0.03 & 0.002 \\
NT-proBNP cut-off (ng/L) & 955 & 4040 & 4815 \\
Sensitivity/Specificity & $0.82 / 0.71$ & $0.70 / 0.76$ & $0.90 / 0.63$ \\
AS (SAVR) & & & \\
AUC [95 \% CI] & $0.86[0.76-0.96]$ & $0.85[0.76-0.94]$ & $0.82[0.70-0.94]$ \\
$p$ Value & 0.014 & 0.017 & 0.03 \\
NT-proBNP cut-off (ng/L) & 975 & 4040 & 4855 \\
Sensitivity/Specificity & $1.0 / 0.74$ & $1.0 / 0.78$ & $1 / 0.73$ \\
AS+CABG (SAVR) & & & \\
AUC [95 \% Cl] & $0.75[0.60-0.90]$ & - & $0.78[0.46-1.0]$ \\
$p$ Value & 0.045 & - & 0.042 \\
NT-proBNP cut-off (ng/L) & 915 & - & 10035 \\
Sensitivity/Specificity & $0.83 / 0.64$ & - & $0.80 / 0.93$ \\
\hline
\end{tabular}

$R O C$, receiver operations characteristics; $A U C$, area under the curve; NT-proBNP, $N$ terminal pro-B-type natriuretic peptide; SAVR, surgical aortic valve replacement; AS, aortic stenosis; CABG, coronary artery bypass grafting. 

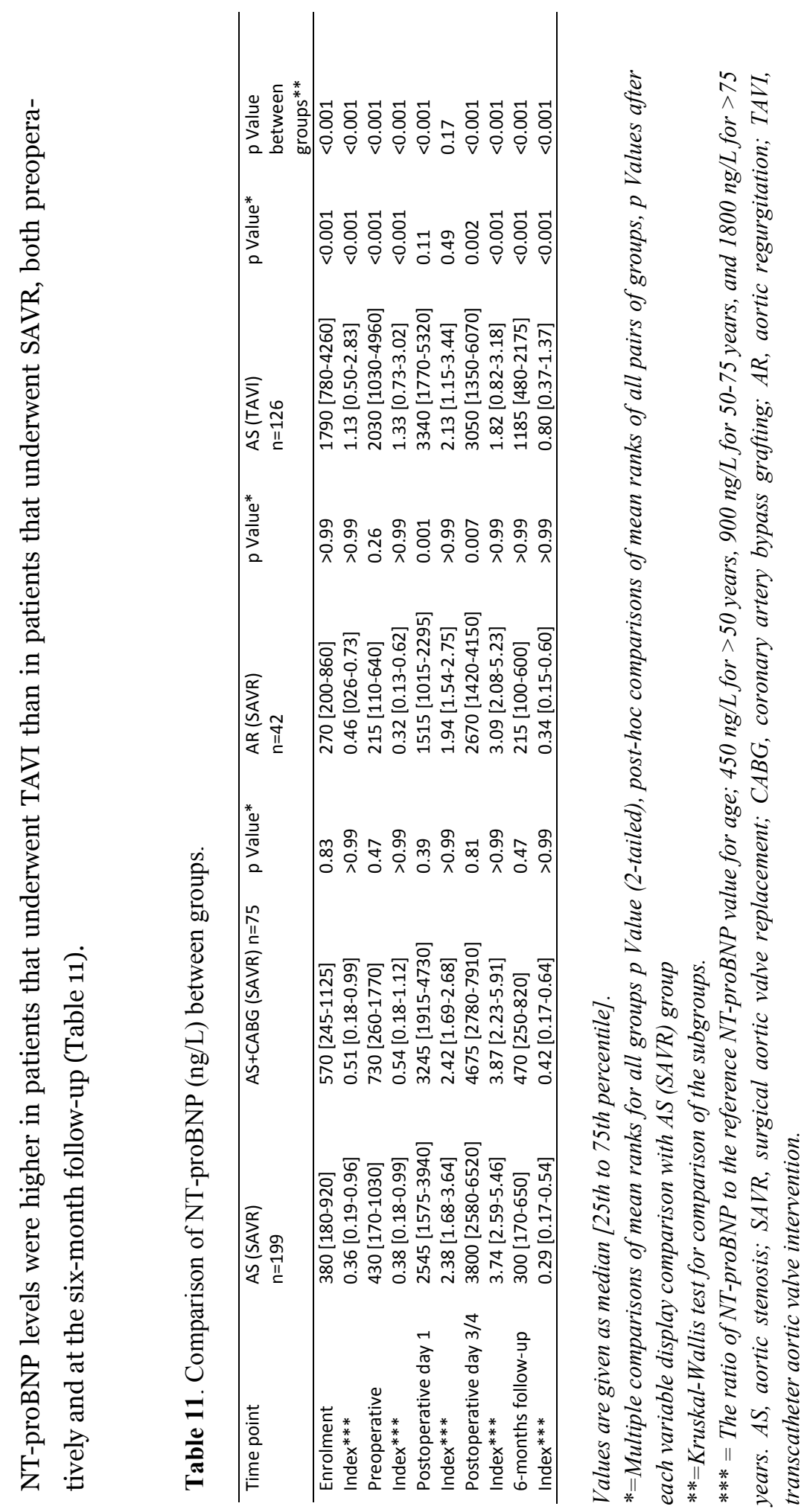


\section{Study IV}

This study included 273 patients scheduled for aortic valve surgery for AS. Preand postoperative LV filling pressures were evaluated in 247 of 273 patients. Patient demographics and preoperative data are shown in Table 12.

Table 12. Baseline characteristics ${ }^{\mathrm{a}}$.

\begin{tabular}{|c|c|c|c|}
\hline Variable & $\begin{array}{l}\text { Preoperative low LV filling } \\
\text { pressure }(n=193)\end{array}$ & $\begin{array}{l}\text { Preoperative high } L V \text { filling } \\
\text { pressure }(n=54)\end{array}$ & P value \\
\hline Age (yrs.) & $70[65-76]$ & $75[67-80]$ & 0.01 \\
\hline Sex female & $89(46 \%)$ & $24(44 \%)$ & 0.82 \\
\hline BMI $\left(\mathrm{kg} / \mathrm{m}^{2}\right)$ & 27 [24-30] & $27[25-30]$ & 0.36 \\
\hline $\operatorname{BSA}\left(\mathrm{m}^{2}\right)$ & $1.9[1.8-2.1]$ & $1.9[1.8-2.1]$ & 0.88 \\
\hline Hypertension & $99(51 \%)$ & $34(63 \%)$ & 0.13 \\
\hline $\begin{array}{l}\text { Diabetes mellitus (insulin } \\
\text { or oral treatment) }\end{array}$ & $28(15 \%)$ & $13(24 \%)$ & 0.09 \\
\hline Angina pectoris & $51(26 \%)$ & $23(43 \%)$ & 0.02 \\
\hline $\mathrm{CHF}$ & $12 / 191(6 \%)$ & $15 / 53(28 \%)$ & $<0.001$ \\
\hline EuroSCORE II & $1.6[1.1-2.7]$ & $3.1[1.6-5.4]$ & $<0.001$ \\
\hline NYHA III/IV & $99(52 \%)$ & $36(67 \%)$ & 0.04 \\
\hline \multicolumn{4}{|l|}{ Biochemistry } \\
\hline P-Cystatin C (mg/L) & $1.1[1.0-1.3] \mathrm{n}=184$ & $1.3[1.0-1.4] \mathrm{n}=53$ & 0.003 \\
\hline $\begin{array}{l}\text { P-Creatinine clearance } \\
\left(\mathrm{ml} / \mathrm{min} / \mathrm{m}^{2}\right)\end{array}$ & $74[61-92]$ & $64[48-81]$ & 0.006 \\
\hline Blood hemoglobin $(\mathrm{g} / \mathrm{L})$ & $140[133-148]$ & $132[123-146]$ & 0.01 \\
\hline NT-proBNP (ng/L) & $320[170-775] n=189$ & $1100[510-3030] \mathrm{n}=53$ & $<0.001$ \\
\hline NT-proBNP >960 (ng/L) & $32 / 189(17 \%)$ & $30 / 53(57 \%)$ & $<0.001$ \\
\hline \multicolumn{4}{|l|}{ Echocardiography } \\
\hline \multicolumn{4}{|l|}{ Systolic LVF } \\
\hline Normal/mild dysfunction & 186/191 (97\%) & $45 / 53(85 \%)$ & 0.002 \\
\hline LV mass index $\left(\mathrm{g} / \mathrm{m}^{2}\right)$ & $125[101-146] n=158$ & $137[109-172] \mathrm{n}=44$ & 0.05 \\
\hline - $>95(\text { female })^{\mathrm{b}}$ & $52 / 72(72 \%)$ & $16 / 18(89 \%)$ & 0.22 \\
\hline$-\quad>115(\text { male })^{c}$ & $65 / 86(76 \%)$ & $20 / 26(77 \%)$ & 0.89 \\
\hline \multicolumn{4}{|l|}{ Diastolic LVF } \\
\hline $\mathrm{E} / \mathrm{A}$ & $0.8[0.7-0.9] \mathrm{n}=193$ & $1.6[1.2-2.1] \mathrm{n}=54$ & \\
\hline $\mathrm{E} / \mathrm{e}$ & $8[6-10] n=191$ & $8[6.5-9.5] \mathrm{n}=54$ & \\
\hline$->14^{\mathrm{d}}$ & $96 / 193(50 \%)$ & $43 / 54(80 \%)$ & \\
\hline LAA index $\left(\mathrm{cm}^{2} / \mathrm{m}^{2}\right)$ & $11.3[9.8-12.9] \mathrm{n}=193$ & $12.9[11.2-15.1] \mathrm{n}=54$ & \\
\hline$->13^{e}$ & $45 / 193(23 \%)$ & $26 / 54(48 \%)$ & \\
\hline $\mathrm{PV} \mathrm{s} / \mathrm{PV} \mathrm{d}^{\mathrm{f}}$ & $1.5[1.3-1.8] \mathrm{n}=192$ & $0.8[0.5-1] \mathrm{n}=54$ & \\
\hline \multicolumn{4}{|l|}{ Aortic valve } \\
\hline EOA $\left(\mathrm{cm}^{2}\right)$ & $0.6[0.5-0.8] \mathrm{n}=192$ & $0.6[0.5-0.8] \mathrm{n}=54$ & 0.10 \\
\hline $\operatorname{iEOA~}\left(\mathrm{cm}^{2} / \mathrm{m}^{2}\right)$ & $0.3[0.3-0.4] \mathrm{n}=192$ & $0.3[0.2-0.4] \mathrm{n}=54$ & 0.12 \\
\hline $\begin{array}{l}\text { Mean pressure gradient } \\
(\mathrm{mmHg})\end{array}$ & $55[44-68] n=188$ & $49[36-69] \mathrm{n}=53$ & 0.11 \\
\hline
\end{tabular}


a Data is given as medians [IQR] or numbers (\%).

$B M I=$ body mass index, $C H F=$ Congestive Heart Failure, EuroSCORE II = European system for cardiac operative risk evaluation, NYHA = New York Heart Association functional classification, $L V F=$ Left ventricular function, LV mass index =Left Ventricular mass $/ B S A, B S A=$ Body Surface Area, ${ }^{b}=$ upper limit values for normal LV mass for females, ${ }^{c}=$ upper limit values for normal LV mass for males, E/A = early diastolic mitral flow velocity/late diastolic mitral flow velocity, E/e' =early diastolic mitral flow velocity/early diastolic myocardial velocity, ${ }^{d}=$ reference value for E/e' indicating high filling pressure (Nagueh S F et al J Am Soc Echocardiogr 2016), LAA index = Left Atrial Area/BSA, ${ }^{e}=$ reference value for enlarged left atrium (Kou $s$ et al Eur Heart J Cardiovasc Imaging 2014;15(6):680-90), $f=$ pulmonary vein systolic flow velocity / pulmonary vein diastolic flow velocity, EOA = Effective Orifice Area, $i E O A=E O A / B S A$

High LV filling pressure was observed in 22\% $(n=54)$ of patients. Among those with elevated preoperative LV filling pressure, half $(27 / 54,50 \%)$ had improved at the six-month postoperative evaluation. Among the 193 patients that presented with low LV filling pressure at the time of surgery, 24 (12\%) had deteriorated to high LV filling pressures at six months (Fig. 8).

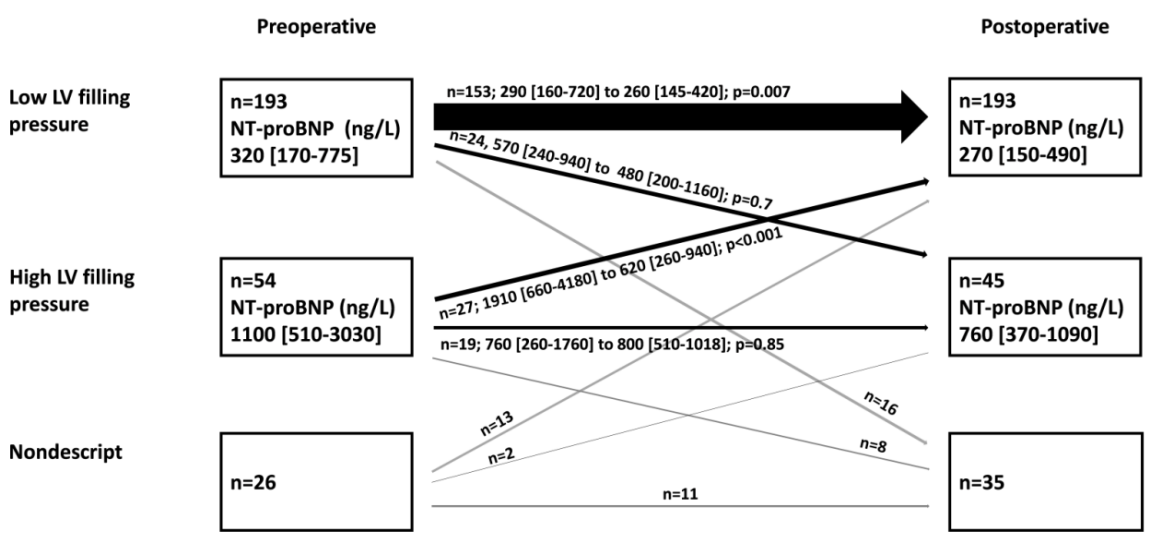

Figure.8 Diastolic function categorized as low or high filling pressure before and 6 months after surgical aortic valve replacement (SAVR) with corresponding levels of NTproBNP (ng/L). 
Peri- and postoperative data and adverse events for patients with low and high preoperative LV filling pressures are presented in Table 13.

Table 13. Perioperative data and adverse events

\begin{tabular}{|c|c|c|c|}
\hline Variable & $\begin{array}{l}\text { Preoperative low LV filling } \\
\text { pressure }(n=193)\end{array}$ & $\begin{array}{l}\text { Preoperative high LV filling } \\
\text { pressure }(n=54)\end{array}$ & P value \\
\hline Concomitant CABG & $48(25 \%)$ & $21(39 \%)$ & 0.04 \\
\hline Elective surgery & $189(98 \%)$ & $54(100 \%)$ & 0.58 \\
\hline Redo surgery & $3(1.6 \%)$ & $1(1.8 \%)$ & $>0.99$ \\
\hline Cross-clamp time ( $\mathrm{min})$ & $70[61-88]$ & $70[62-87]$ & 0.87 \\
\hline ECC-time (min) & 96 [83-117] & $101[85-126]$ & 0.42 \\
\hline \multicolumn{4}{|l|}{ Outcome } \\
\hline Time on ventilator (hrs.) & $3[2-5]$ & $4[3-8]$ & 0.04 \\
\hline Time in ICU (hrs.) & $21[17-22]$ & $22[21-24]$ & 0.02 \\
\hline CK-MB day 1 & $19[14-27]$ & $18[12-27] n=52$ & 0.59 \\
\hline $\begin{array}{l}\text { P-Creatinine }(\mu \mathrm{mol} / \mathrm{L}) \text { max- } \\
\text { imum }\end{array}$ & $87[70-106] n=192$ & $106[83-134]$ & $<0.001$ \\
\hline $\begin{array}{l}\text { P-Creatinine }(\mu \mathrm{mol} / \mathrm{L}) \text { at } \\
\text { discharge }\end{array}$ & $81[67-99] \mathrm{n}=192$ & 88 [76-119] & 0.003 \\
\hline P-Cystatin C (mg/L) Day 3 & $1.3[1.1-1.6] \mathrm{n}=180$ & $1.6[1.3-1.9]$ & 0.002 \\
\hline Postoperative AF & $84 / 193(44 \%)$ & $24 / 53(45 \%)$ & 0.72 \\
\hline Stroke & $2 / 193(1.0 \%)$ & 0 & $>0.99$ \\
\hline PMI & $7 / 193(3.6 \%)$ & $2(3.8 \%)$ & $>0.99$ \\
\hline PHF & $14(7.3 \%)$ & $12(22.2 \%)$ & 0.002 \\
\hline $\begin{array}{l}\text { Reoperation valve failure or } \\
\text { PVL }\end{array}$ & 0 & 0 & \\
\hline Reoperation DSWI & 0 & $1(1.9 \%)$ & 0.22 \\
\hline 30 day mortality & 0 & $1(1.9 \%)$ & $>0.22$ \\
\hline 1 year mortality & $4(2.1 \%)$ & $2(3.7 \%)$ & $>0.61$ \\
\hline Long term mortality* & $38(20 \%)$ & $14(26 \%)$ & 0.32 \\
\hline
\end{tabular}

${ }^{a}$ Data is given as medians [IQR] or numbers (\%).

$A F=$ Atrial Fibrillation, $C A B G=$ Coronary artery bypass surgery, ECC $=$ Extra corporeal circulation, ICU=Intensive care unit, $P M I=$ Perioperative myocardial infarction, PHF=Postoperative heart failure, $P V L=$ Paravalvular leakage, DSWI=Deep Sternal Wound infection. ${ }^{*}=$ Median follow-up 7.1 (4.1-9.1) years.

Both the bypass time and the cross-clamp time were longer in the group that experienced a deterioration in low LV filling pressures, compared to those that maintained low LV filling pressures, at the six-month postoperative echocardiographic evaluation (Table 14). 


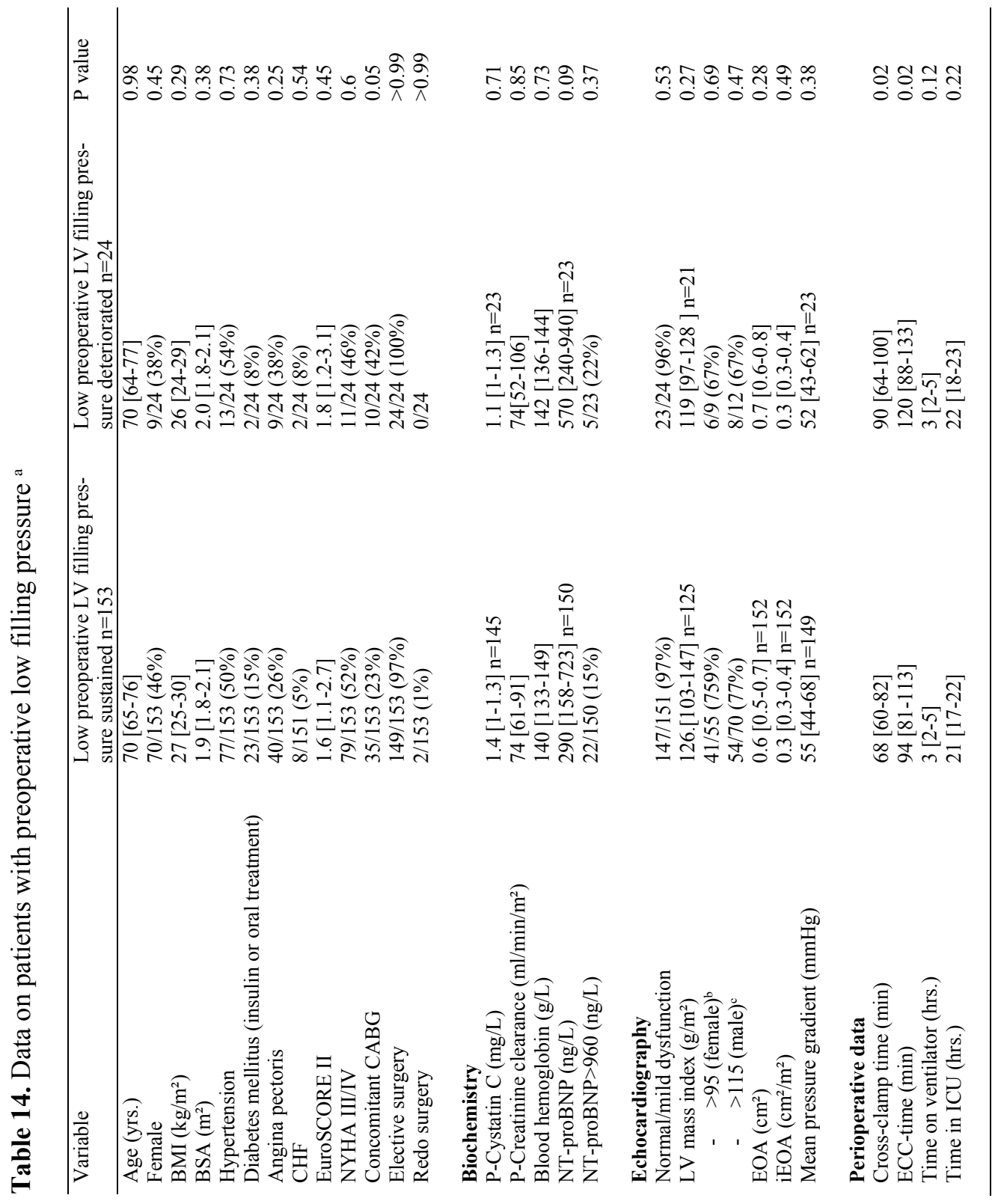




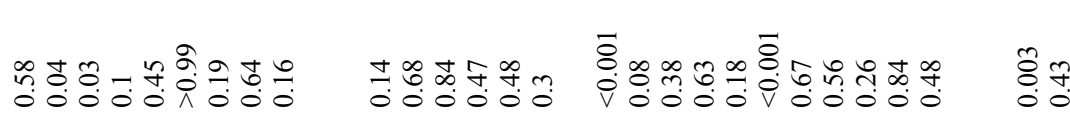

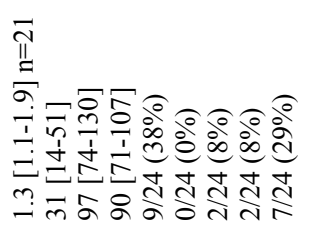

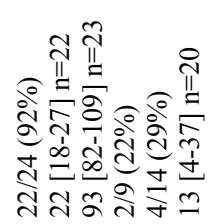

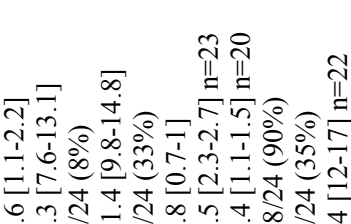

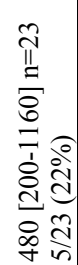

$\frac{\sqrt{2}}{\sqrt{2}}$

$=$

है ङ

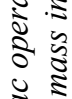

:

ปิ

i.

ह

के $\frac{\pi}{3}$

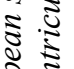

$\frac{2}{2}$

这菑

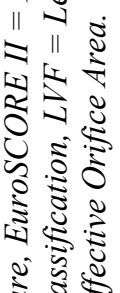

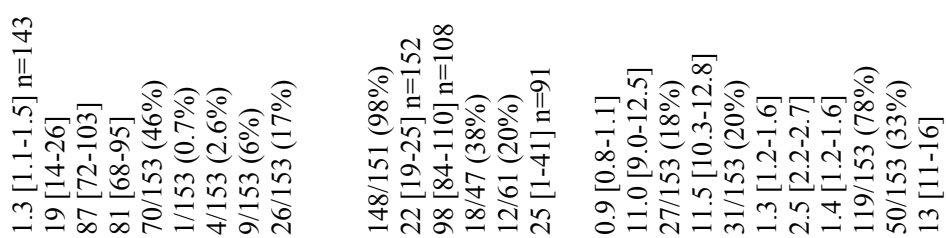

咅造

전

ำ

ป 5 :

है ई

0
0
0
0
0

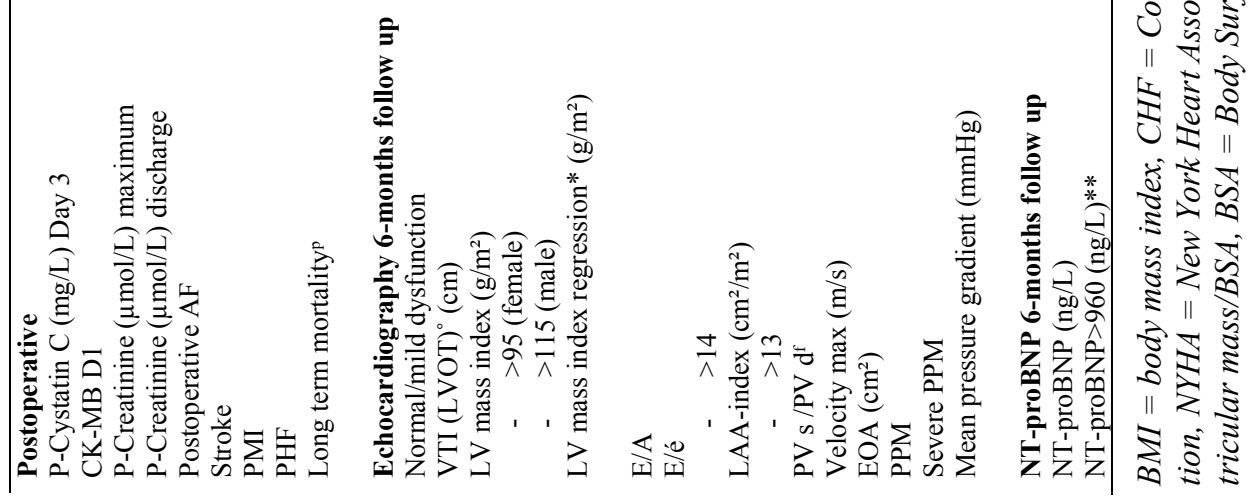


${ }^{a}$ Data is given as medians [IQR] or numbers (\%).

$b=$ upper limit values for normal LV mass for females,

$c=$ upper limit values for normal LV mass for males, $E / A=$ early diastolic filling velocity/late diastolic filling velocity, E/e' =early diastolic filling velocity/early diastolic myocardial velocity, $d=$ reference value for E/e' indicating high filling pressure (Nagueh S F et al J Am Soc Echocardi ogr 2016), LAA index = Left Atrial Area/BSA,

$e=$ reference value for enlarged left atrium (Kou s et al Eur Heart J Cardiovasc Imaging 2014;15(6):680-90),

$f=$ pulmonary vein systolic flow velocity/ pulmonary vein diastolic flow velocity, ${ }^{g}=$ Median followup 7.1 (4.1-9.1) years * = Preoperative LV mass index-Postoperative LV mass index, **= best cut off point for preoperative NT-proBNP in regard for discriminating 5 year mortality. 
Coronary artery bypass surgery (CABG) was significantly more common in patients that experienced a deterioration in diastolic function $(n=10,42 \%)$ compared to those that maintained diastolic function $(n=35,23 \%$; $p=0.049)$. At six months after surgery, patients with improved LV filling pressures had higher NT-proBNP levels (1910 [623-4410] ng/L) than patients that retained high LV filling pressures (NTproBNP: 760 [260-1760] ng/L; p=0.035; Table 15). 


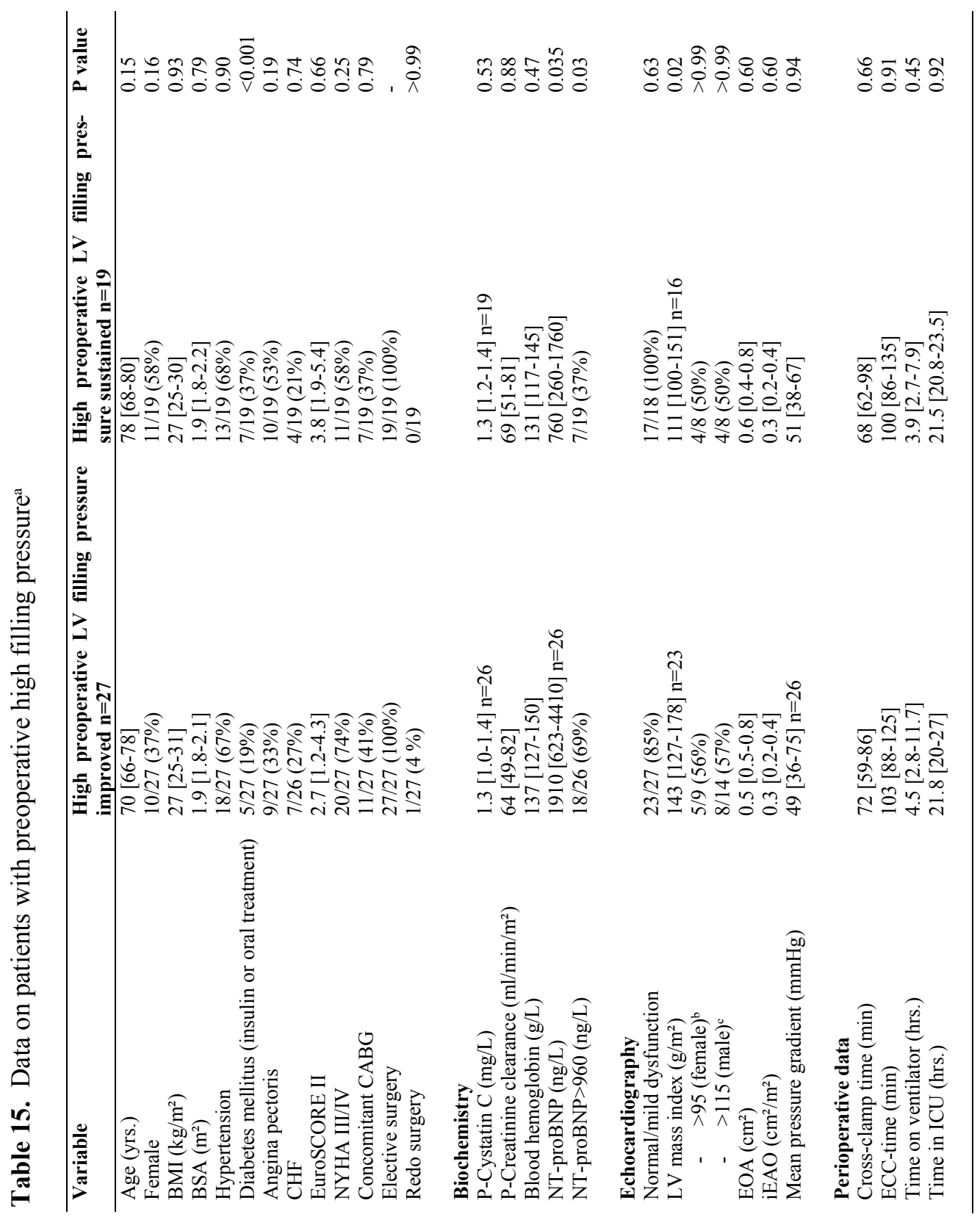




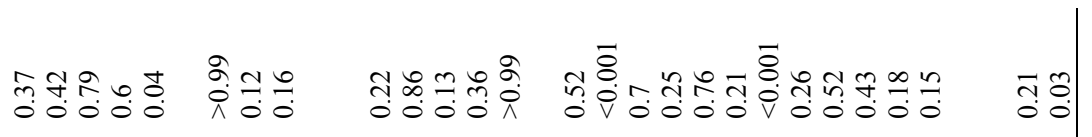

$\stackrel{\infty}{=}$

무유

ำ่ㅊำ

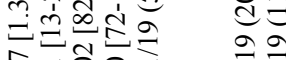

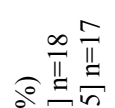

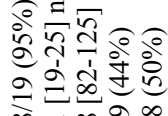

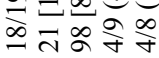

늘

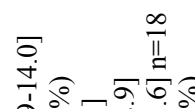

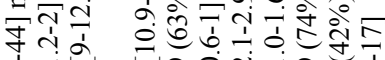

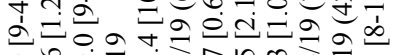

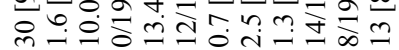

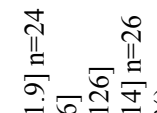

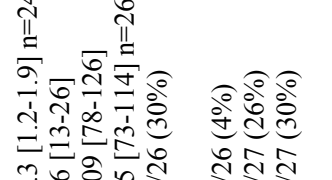
m응ㅇำ

苯密

m.

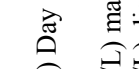

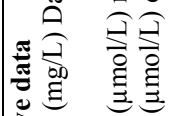

可西

U.

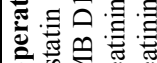

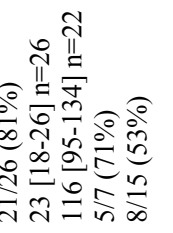

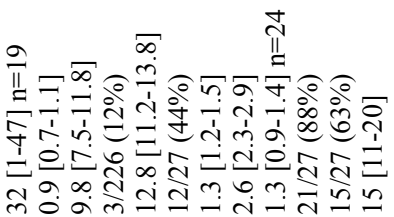

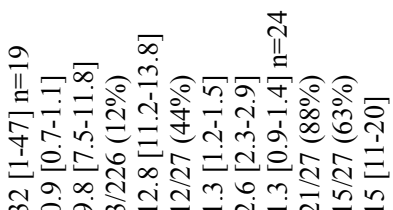

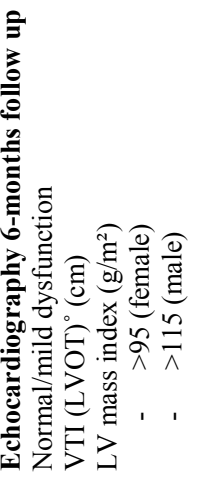

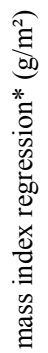

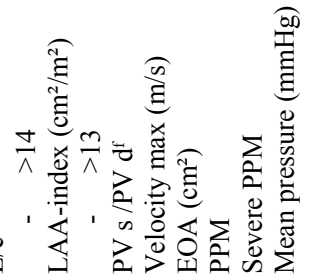

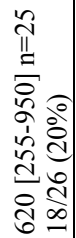

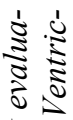

这文

त $\pi$

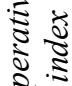

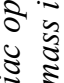

ป

อิ

竎弯

I

के ई․

ล่ं

8인

$\approx \|$

过过

象

胥造

월

₹ $\frac{2}{2}$

近

ปิ .

8

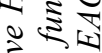

离 5

일. ن

ए

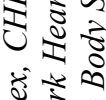

* *

है

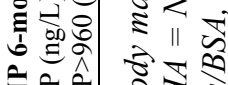

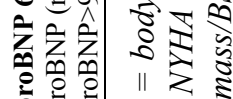

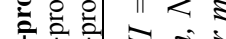

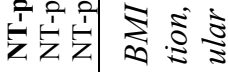


${ }^{a}$ Data is given as medians [IQR] or numbers (\%).

$b=$ upper limit values for normal LV mass for females,

$c=$ upper limit values for normal LV mass for males, $E / A=$ early diastolic filling velocity/late dias tolic filling velocity, E/e' = early diastolic filling velocity/early diastolic myocardial velocity,

$d=$ reference value for E/e' indicating high filling pressure (Nagueh $S$ F et al J Am Soc Echocardi ogr 2016), LAA-index = Left Atrial Area/BSA,

$e=$ reference value for enlarged left atrium (Kou s et al Eur Heart J Cardiovasc Imaging 2014;15(6):680-90),

$f=$ pulmonary vein systolic flow velocity/ pulmonary vein diastolic flow velocity, ${ }^{g}=$ Median followup 7.1 (4.1-9.1) years * = Preoperative LV mass index-Postoperative LV mass index, **= best cut off point for preoperative NT-proBNP in regard for discriminating 5 year mortality. 
Patients with high LV filling pressures had higher NT-proBNP levels, both pre- and postoperatively, compared to patients with low LV filling pressures (Tables 12, 13). However, both groups showed significant reductions in NT-proBNP levels postoperatively (Fig. 8).

Pre- and postoperative NT-proBNP levels in patients with low and high LV filling pressures are presented in Figure 9.

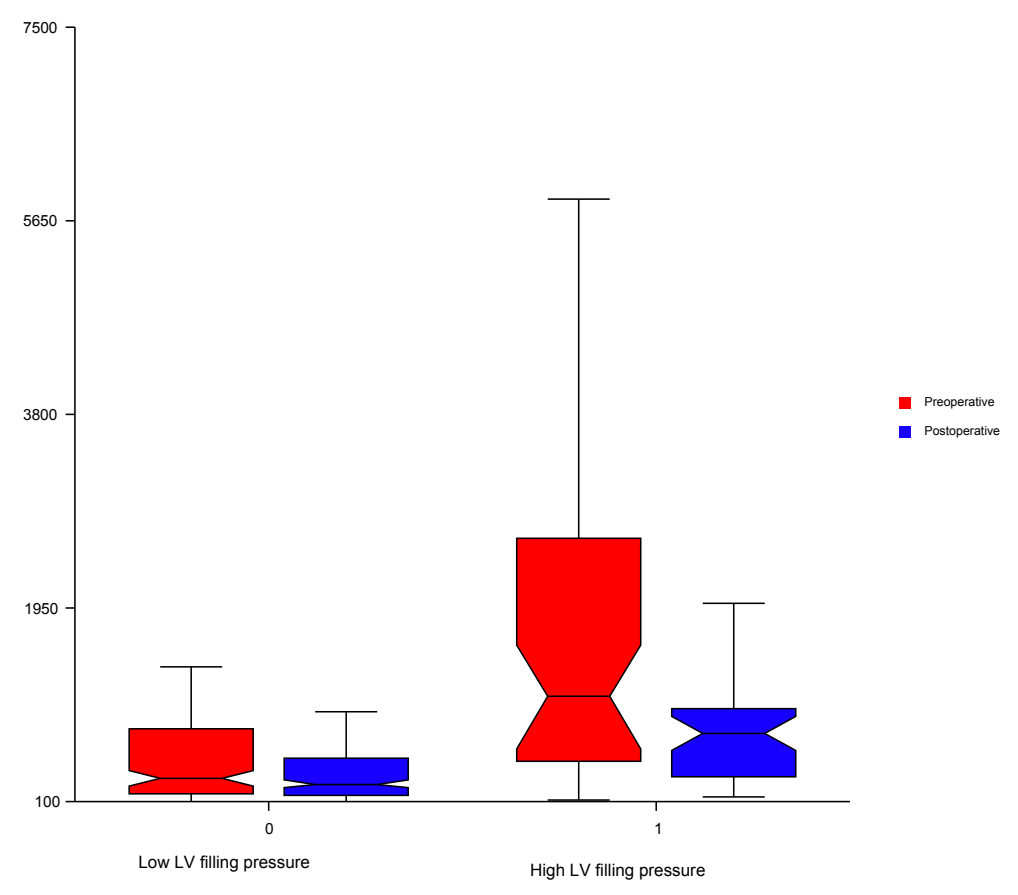

Figure 9. NT-proBNP pre- and postoperatively in patients with Low vs. High LV filling pressure before surgery. NT-proBNP was significantly higher in patients with High LV filling pressure both preoperatively and postoperatively $(\mathrm{p}<0.001)$. 
The relationships between pre- and postoperative NT-proBNP levels and the preoperative left atrial area index are presented in Figure 10.

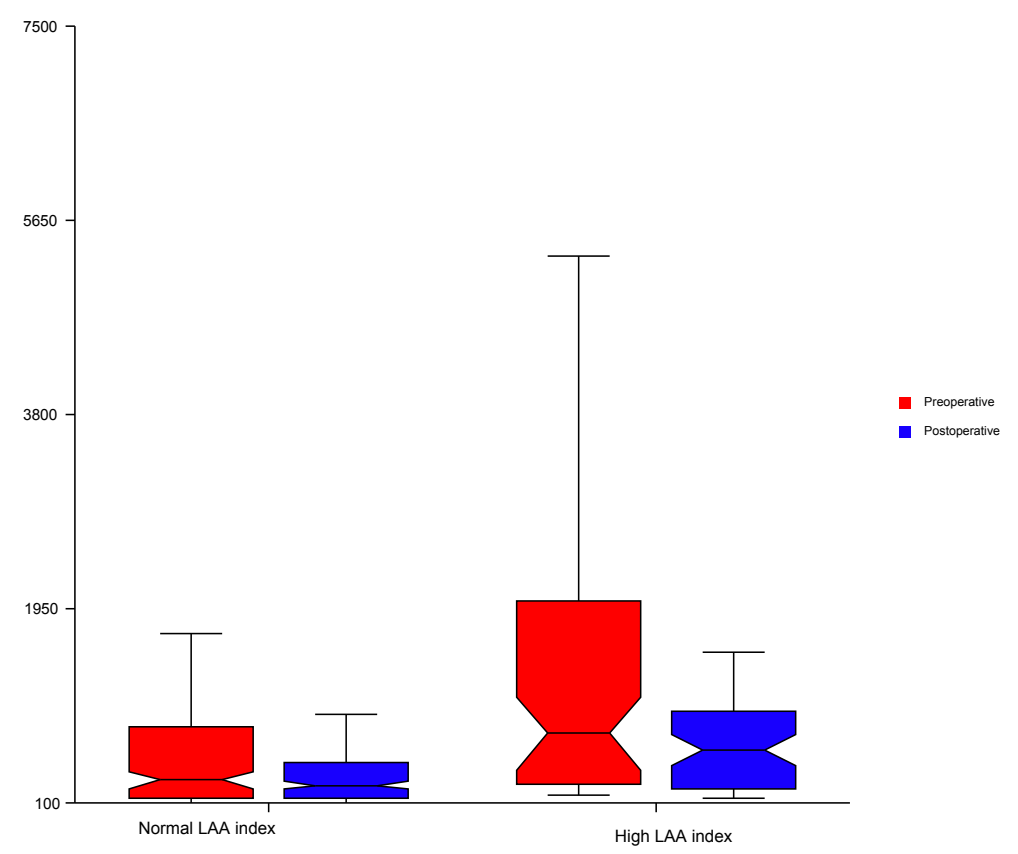

Figure 10. NT-proBNP pre- and postoperatively in patients with Normal vs. preoperative High LAA index before surgery. NT-proBNP was significantly higher in patients with High LAA index both preoperatively and postoperatively $(\mathrm{p}<0.001)$. 
Figure 11 shows the relationship between pre- and postoperative NT-proBNP levels and preoperative E/é values that were below or above 14 .

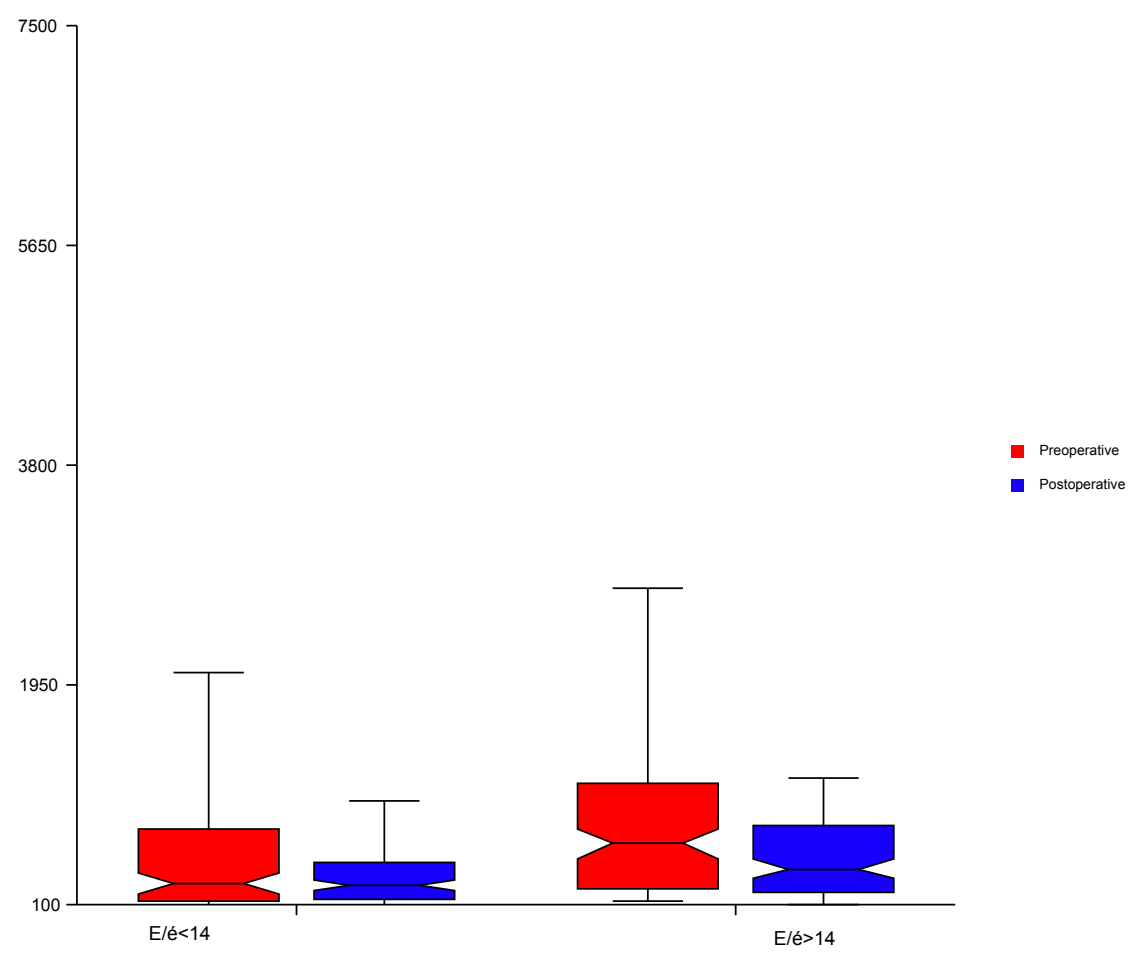

Figure 11. NT-proBNP pre- and postoperatively in patients with E/é $<14$ vs. E/é $>14$ before surgery. NT-proBNP was significantly higher in patients with E/é $>14$ both preoperatively $(\mathrm{p}<0.001)$ and postoperatively $(\mathrm{p}=0.01)$.

The proportion of patients with normal LV systolic function was lower in the high LV filling pressure group $(\mathrm{n}=34,63 \%)$ than in the low LV filling pressure group ( $\mathrm{n}=174,90 \% ; \mathrm{p}<0.001)$. Postoperatively, LV mass decreased significantly in both groups (Table 13). Although the LV mass decline was similar in both groups, those with high preoperative LV filling pressures had higher postoperative LV-mass indices than those with low preoperative LV filling pressures (Table 13). The median follow-up for this study was 7.1 years (range: 4.1 to 9.1 years). During that period, 63 patients died (23\%). Variables associated with long-term mortality, based on a Cox regression analysis, are presented in Table 16. 
Table 16. Cox regression mortality, univariable and multivariable.

\begin{tabular}{|c|c|c|c|c|c|}
\hline Variable & $\begin{array}{l}\text { Regression Coef- } \\
\text { ficient (B) }\end{array}$ & $\mathrm{SE}$ & p-value & RR & $95 \% \mathrm{CI}$ \\
\hline Age (Yrs.) & 0.07 & 0.02 & $<0.001$ & 1.07 & $1.03-1.10$ \\
\hline Male & Ref. & & & & \\
\hline Female & -0.63 & 0.27 & 0.02 & 0.53 & $0.31-0.90$ \\
\hline BMI & -0.003 & 0.03 & 0.92 & 1.00 & $0.94-1.06$ \\
\hline P-Creatinine clearance $\left(\mathrm{ml} / \mathrm{min} / \mathrm{m}^{2}\right)$ & -0.02 & -0.04 & $<0.001$ & 1.00 & $0.96-0.99$ \\
\hline $\operatorname{CCT}(\min )$. & 0.01 & 0.006 & 0.08 & 1.01 & $1.00-1.02$ \\
\hline $\mathrm{ECC}$ (min.) & 0.009 & 0.003 & 0.003 & 1.01 & $1.00-1.01$ \\
\hline NT-proBNP>960 (ng/L) & 1.3 & 0.26 & $<0.001$ & 3.59 & $2.15-6.0$ \\
\hline $\mathrm{DM}$ & 0.69 & 0.28 & 0.01 & 2.01 & $1.15-3.51$ \\
\hline HT & 0.44 & 0.27 & 0.09 & 1.56 & $0.93-2.62$ \\
\hline Cardiac failure & 1.01 & 0.29 & $<0.001$ & 2.75 & $1.55-4.86$ \\
\hline Concomitant CABG & 0.69 & 0.26 & 0.008 & 1.99 & $1.20-3.30$ \\
\hline Preoperative high filling pressure & 0.35 & 0.31 & 0.26 & 1.42 & $0.77-2.63$ \\
\hline Systolic function & & & & & \\
\hline Mild - severe LV dysfunction & 0.77 & 0.32 & 0.02 & 2.17 & $1.15-4.08$ \\
\hline PHF & 1.23 & 0.28 & $<0.001$ & 3.44 & $1.98-5.95$ \\
\hline PMI & 1.33 & 0.43 & 0.002 & 3.76 & $1.62-8.74$ \\
\hline \multicolumn{6}{|l|}{ Final model } \\
\hline NT-proBNP>960 (ng/L)* & 0.90 & 0.30 & 0.002 & 2.47 & $1.38-4.41$ \\
\hline Age (Yrs.) & 0.06 & 0.02 & 0.004 & 1.06 & $1.02-1.10$ \\
\hline DM (insulin or oral treatment) & 0.87 & 0.31 & 0.005 & 2.38 & $1.30-4.32$ \\
\hline Female & -0.87 & 0.32 & 0.006 & 0.42 & $0.22-0.78$ \\
\hline
\end{tabular}

$B M I=B o d y$ mass index, $C C T=$ Cross-clamp time, $E C C=$ Extra corporeal circulation, $D M=$ Diabetes Mellitus, $H T=$ Hypertension, $C A B G=$ Coronary artery bypass surgery, $P H F=$ Postoperative heart failure, $P M I=$ Perioperative myocardial infarction (defined as Troponin $T \geq 2000 \mathrm{ng} / \mathrm{L}$ on the third postoperative day or later), *= best cut off point for preoperative NT-proBNP in regard for discriminating 5 year mortality.

No significant differences in long term mortality depending on pre- or postoperative high LV filling pressure were found (Fig.12, panel A and B). A ROC analysis showed that a preoperative NT-proBNP level of $960 \mathrm{ng} / \mathrm{L}$ was the best cut-off value for predicting all-cause five-year mortality; the AUC was 0.7 (95\% CI: 0.6-0.8, p=0.001). Figure 12 (panels $\mathrm{C}$ and D) shows cumulative survival curves, constructed according to the Kaplan-Meier method. 

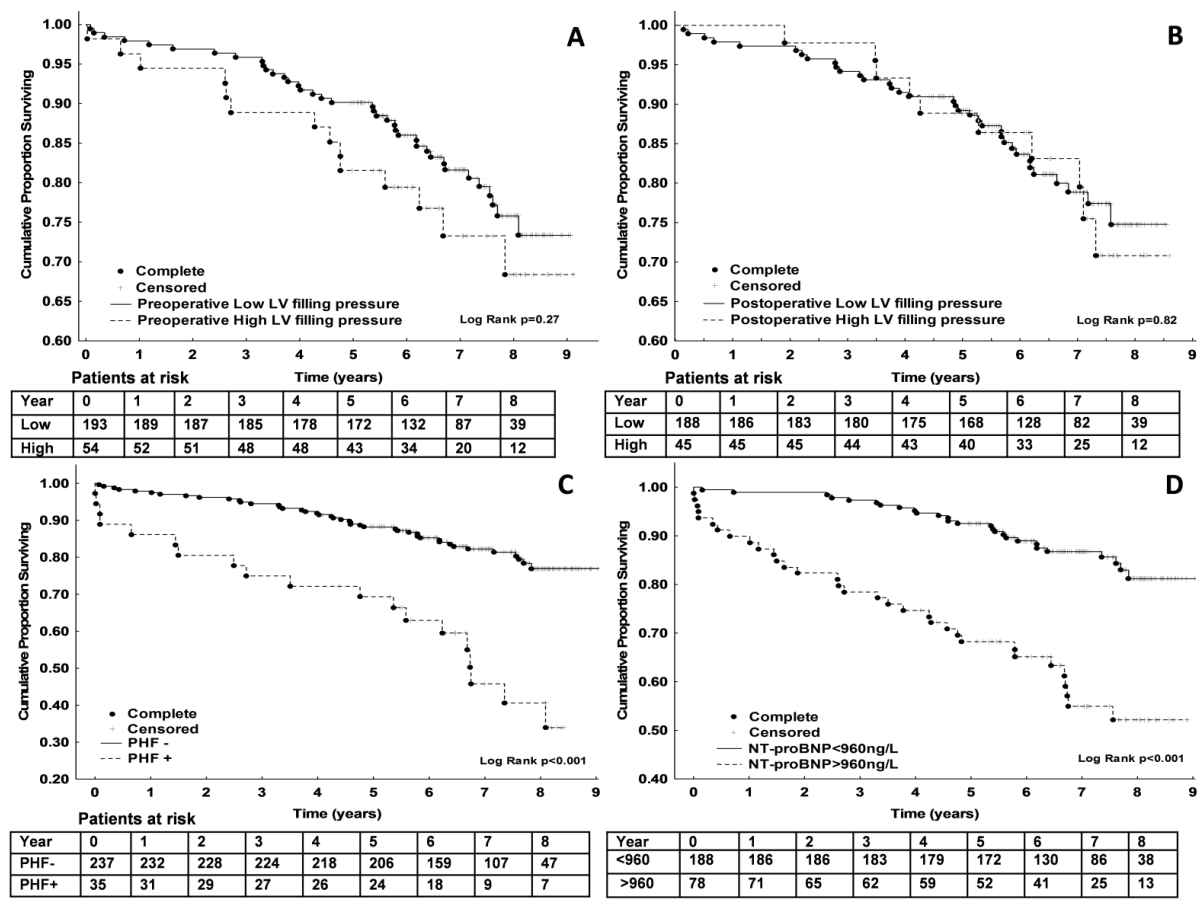

Figure 12. Kaplan-Meier survival curves categorized according to preoperative diastolic function (A) and postoperative diastolic function at the 6 months follow up (B). Episode of PHF (C) and preoperative NT-proBNP above or below $960 \mathrm{ng} / \mathrm{L}(D)$. 


\section{DISCUSSION}

Although aortic valve surgery typically provides excellent results, even in older patients with a high burden of comorbidities, PHF remains a considerable cause of postoperative morbidity and mortality ${ }^{6}$. Currently, we have TAVI in our armament for treating the oldest and sickest patients; nevertheless, these patients also experience cardiac-related complications in association with the intervention ${ }^{70}$. Some issues have remained unanswered, including; how to select the intervention that will provide the most benefit to each patient; how to optimize the timing of an intervention; and how long can we refrain from an intervention in asymptomatic patients, before causing more harm than good? This dissertation cannot answer all these questions, but hopefully, our findings will add to existing knowledge to provide a better understanding of these matters.

\section{PHF}

No definition of PHF or low cardiac output syndrome exists that is universally accepted. Therefore, different definitions are used in literature 86 , 101. The difficulty in finding a definition for PHF can be appreciated by considering the editorial published by the journal, Cardiovascular Research, where they endeavoured to find a definition of heart failure by surveying their reviewers ${ }^{102}$. We overcame this issue by devising the definition of PHF described in the Methods section. Bias was addressed by the use of a blinded Clinical Endpoints committee.

A previous study showed that PHF was an independent risk factor for late mortality after SAVR for AS ${ }^{8}$. In that analysis, the weight of the preoperative risk score (EuroSCORE) was not included. Although the EuroSCORE was created to predict operative mortality after cardiac surgery, it can also predict long-term outcome ${ }^{81}$. The results from our work confirmed the 
concept that patients at high risk of operative mortality carried that risk over time. However, we also provided a new finding, which was the serious effect PHF had over time in patients that were assigned to a low-risk group. We found that patients at low risk that were treated for PHF, and otherwise successfully discharged from the hospital, were in danger of a premature death. The European Society of Cardiology and The European Association of Cardiothoracic Surgery, in their latest (2017) guidelines for the management of valvular heart disease, emphasized that heart failure after valve surgery should be treated according to relevant guidelines for heart failure 35. This guideline indicated that surgeons must emphasize in the discharge records that a patient had experienced an episode of PHF, and that increased attention is warranted during follow-up. This guideline is important, because active surveillance and treatment has been shown to improve the prognosis of patients with chronic heart failure ${ }^{103,104}$. A previous report on this particular cohort identified five preoperative risk factors (pulmonary hypertension, severe systolic LV dysfunction, history of congestive heart failure, hypertension, and unstable preoperative hemodynamics) and two intra-operative risk factors (long cross-clamp times and a perioperative myocardial infarction) for PHF ${ }^{82}$. We could not explain why patients at low risk that developed PHF had such a poor prognosis; neither severe systolic dysfunction nor the other known risk factors for PHF emerged as independent risk factors for late mortality ${ }^{8}$. Diastolic function was not investigated in our previous works on PHF, although diastolic dysfunction has been reported to have a negative effect on longterm survival after surgery for AS 58, 105. Taking this observation into account, we surmised that diastolic dysfunction could be the missing link in understanding PHF development. Consequently, we hypothesized that a preoperative evaluation of diastolic dysfunction, perhaps with an adjunct of available biomarkers for heart failure, such as NT-proBNP, might shed light on PHF development. In our second study, we showed that NTproBNP could predict short-term mortality in patients with CAD. This 
finding provided prognostic information about patients with CAD and MR, with regard to the development of severe PHF.

\section{NT-proBNP and PHF}

The results of the second study showed that valvular pathologies, such as AS and MR, were associated with higher preoperative NT-proBNP levels than $\mathrm{CAD}$, upon admission to surgery. This finding was consistent with previous studies ${ }^{106-113}$. The novelty of this finding was that it held true, even after adjusting for known confounders. Several confounding factors that are not directly related to underlying heart disease are known to increase NT-proBNP, including older age, female gender, and renal function ${ }^{114-116}$; in contrast, only one of these confounding factors, obesity, was associated with lower levels of NT-proBNP 117.

Our results suggested that the release of NT-proBNP was more dependent on pressure overload (e.g., in AS) or volume overload (e.g., in MR) than on ischemia alone. In valvular pathology, there is evidence that NTproBNP release is elicited by the hemodynamic effects on the ventricle, rather than by the severity of the valvular lesions ${ }^{118,119}$. The mechanism involved in NT-proBNP release in ischemia is not entirely clear ${ }^{120}$, although $\mathrm{Xu}$ et al. observed a relationship between NT-proBNP and CAD severity ${ }^{121}$. The results of our study supported previous findings that showed that, in cardiac surgery, NT-proBNP levels were associated with morbidity and mortality ${ }^{122-126}$. In contrast to other studies, we found that the ability of NT-proBNP to predict severe PHF was less convincing in the context of AS ${ }^{108}$. There could be several reasons for this finding. The incidence of severe PHF was low in patients with AS in our cohort, even though we had a rather large sample size. In addition, the discrepancy between our findings and those of other studies could have been due to differences in endpoints, follow-up times, sample sizes, and/or surgery timing. However, the healthcare systems and the availability of cardiothorac- 
ic surgery in Sweden allow most patients to be treated in accordance with current guidelines ${ }^{127,128}$.

Although the second study was a rather large study, one limitation was its retrospective nature. Moreover, the follow-up time was relatively short, which was a major reason for the less clear predictive value of NT-proBNP in AS. Further studies on the relationship between NT-proBNP and PHF are needed with longer follow-up times. We addressed this issue in the third and fourth studies.

Timing is of essence in heart treatments; thus, we strive to intervene on patients with AS at an optimal time. If we intervene too early, the risk associated with the intervention might exceed the gain. On the other hand, if we operate too late, the underlying heart disease might have caused irreversible damage, which could prevent the patient from gaining the full benefit of the procedure. In the third study, for the first time, to our knowledge, the levels of NT-proBNP was described from a preoperative assessment to the six-month follow-up in a cohort of unselected patients that underwent an aortic valve intervention. By selecting patients that underwent either SAVR or TAVI, we could compare the two different procedures. Despite a median of four months between the preoperative evaluations to the intervention, none of the groups showed increases in NTproBNP levels while awaiting the valve intervention. Moreover, none of the patients appeared to deteriorate during the time spent on the waiting list. Interestingly, patients with NT-proBNP levels above the upper reference limit (URL) had shorter waiting times compared to those with NTproBNP levels below the URL, even though the NT-proBNP results remained blinded. Our results supported associations between NT-proBNP levels and factors that influenced the waiting time 47,129 .

All aortic valve interventions elicit a rise in NT-proBNP. In SAVR, the rise was more pronounced and levels peaked on the third day, compared to TAVI, which displayed a less pronounced rise and a peak on the first postoperative day ${ }^{109,}{ }^{130-132}$. Interestingly, we found no difference in the 
change in NT-proBNP ( $\triangle$ NT-proBNP, calculated as the third-day value subtracted from the preoperative value) between AS (SAVR) and AS+CABG (SAVR). However, we observed a significantly smaller $\triangle \mathrm{NT}$ proBNP with aortic insufficiency (SAVR). We believe that this difference was not dependent on the surgical trauma, because the cross-clamp time and extracorporeal circulation time showed no correlation with the $\Delta$ NTproBNP, and the surgical traumas were similar. More likely, the difference was due to patient-related factors and the degree of cardiac dysfunction ${ }^{133-135 .}$

The postoperative rise in NT-proBNP is undoubtedly related to the surgical intervention. However, it is also influenced by age, preoperative cardiac function, the degree of perioperative ischemia, and the development of $\mathrm{PHF}$, as suggested by the multivariable linear regression model. In TAVI, higher preoperative and postoperative levels of NT-proBNP were observed compared to the surgical cohort. These differences were probably a reflection of the older mean age in the TAVI group and the increased risk profile, with more comorbidity, compared to the SAVR group. The earlier and less pronounced rise in NT-proBNP observed in TAVI was probably due to the reduced trauma associated with this intervention, compared SAVR. The variance in NT-proBNP observed in the postprocedural rise in TAVI could to $20 \%$ be explained by systolic LV function and ischemia, which was evidenced as a rise in CK-MB.

As part of the ongoing debate on the optimal timing of aortic interventions, it has been suggested that serial measurements of NT-proBNP should be performed 39 . Our results showed that high pre- and early postoperative levels of NT-proBNP were associated with mortality, which was consistent with other studies $41,136,137$. We also showed that an aortic valve intervention had a beneficial effect on NT-proBNP levels, even in patients with the highest preoperative levels. However, we could not find an association between high preoperative or early postoperative NT-proBNP levels and mortality in patients that received TAVI. These results contrasted 
with results from other studies ${ }^{138}$, 139 , but they were consistent with results from the study by Seiffert et al. ${ }^{140}$. One explanation for this discrepancy could be that patients treated with TAVI in our cohort were older and had more comorbidity, compared to those deemed fit to undergo SAVR. These factors could have reduced the power of NT-proBNP levels for predicting mortality ${ }^{141}$.

Our cohort was one of the largest reported among prospective studies that evaluated NT-proBNP levels in patients that underwent SAVR and TAVI. Nevertheless, the TAVI group was too small and the number of events too low for sufficient statistical power to detect the ability of NT-proBNP to predict mortality. Only the SAVR group had sufficient statistical power to detect the predictive ability of NT-proBNP. On the other hand, we showed that all interventions had a beneficial effect on NT-proBNP, independently of pathophysiology, preoperative levels, and the type of intervention. However, high early postoperative levels should warrant increased surveillance and follow-up, according to the guidelines for chronic heart failure 35 .

\section{Diastolic dysfunction, NT-proBNP and PHF}

In our fourth study, we found that 22\% (54/247) of patients had signs of high preoperative LV filling pressures. This proportion might appear

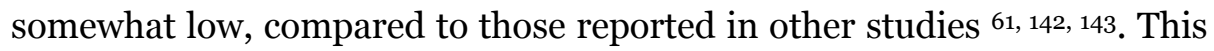
discrepancy could be due to differences in cohorts, the types of procedure, referral patterns, and different indices used for classifying diastolic dysfunction $5^{6}$.

One of our main findings was that half of the patients with high preoperative LV filling pressures had normalized LV filling pressures at six months after surgery. In contrast, $12 \%(n=24)$ of patients with low LV filling pressures deteriorated and had high LV filling pressures at six months after surgery. Perhaps patients that showed early improvements in diastolic 
function represented a subset of patients with reversible hypertrophy. Villari et al. reported a worsening in diastolic function early after aortic valve replacement, due to a relative increase in fibrosis as the muscular hypertrophy subsided. Improvements in diastolic function typically takes years, due to the slow regression of fibrosis ${ }^{144}$. Patients that deteriorated in our study tended to have longer aortic cross-clamping times and longer bypass times. CABG was also more common in that group, which suggested that they experienced profound surgical trauma, such as intraoperative ischemic injury. This possibility was supported by the higher levels of Creatine Kinase-MB (CK-MB) observed in that group. Moreover, this possibility was supported by results from previous studies ${ }^{145}, 146$.

In the present study, NT-proBNP was found to be the sole predictor of high preoperative LV filling pressure, after adjusting for confounders. Additionally, previous studies have shown an association between NTproBNP and diastolic function 37, 147-150. Our method for the evaluation of high LV filling pressure, starting with E/A taking the age adjusted normal ranges into account for grading of diastolic function, was at least as good as left atrial index and E/é in identifying patients with increased levels of NT-proBNP. In our study, high pre- and postoperative LV filling pressures were associated with elevated NT-proBNP. Nevertheless, there was also a significant decrease in NT-proBNP postoperatively, in both groups, compared to preoperative levels.

A novel finding from this study was that patients with high preoperative LV filling pressures that achieved normalized LV filling pressures postoperatively had significantly higher preoperative levels of NT-proBNP and higher LV-mass indices than patients that experienced no improvement in LV filling pressure. However, patients in the high preoperative LV filling pressure group that did not improve (i.e., they maintained high LV filling pressures at the six-month follow-up) had higher frequencies of diabetes mellitus and atrial fibrillation. These results implied that patients that did not show improvements in LV filling pressure might have 
had a more permanent cardiac dysfunction, possibly due to fibrosis ${ }^{151,152}$. Although high preoperative LV filling pressures were associated with PHF and longer ICU stays, we could not find an association between diastolic dysfunction and mortality. In study I, we suggested that diastolic dysfunction might be the underlying myocardial factor responsible for the delayed consequences of PHF 153. Indeed, the association between NTproBNP and a poor long-term outcome supported the assumption that an underlying myocardial factor might play a key role in PHF-related mortality. Although our results clearly discarded elevated LV filling pressure as the culprit involved in long-term mortality, we could not rule out the possibility that diastolic dysfunction due to fibrosis might play a role. The methods used in this study could not differentiate between high LV filling pressures caused hypertrophy and those caused by fibrosis. It is also possible that the permanence or transience of fibrosis might play different roles in diastolic dysfunction in the presence of aortic valve disease. Indeed, these potentially different roles of fibrosis might explain the conflicting results found on the impact of diastolic dysfunction on prognosis after AVR for AS 61, 142 .

The results from the fourth study described in this dissertation confirmed our previous results that both PHF and high preoperative NT-proBNP were associated with poor long-term survival. A limitation in this study was that we did not distinguish between cardiac-related deaths and deaths from other causes. Missing data and the possibility of a type II error could have influenced our results. However, it was apparent that factors other than diastolic dysfunction were of greater importance for the outcome. One of the strength of the fourth study is that we used several Doppler parameters as recommended in the guidelines in evaluating LV filling pressure as opposed to evaluating, for instance only the E/é ratio that is widely used ${ }^{154}$. The Euro-filling study demonstrates that assessement of LV filling pressure non-invasively using the current guidelines are both reliable and useful in estimating invasive LV end-diastolic 
pressure (LVEDP) ${ }^{154}$. In the future, a potential avenue of exploration could be to quantify and relate fibrosis to diastolic function and prognosis, possibly by evaluating images acquired with different techniques, such as magnetic resonance imaging (MRI). 


\section{CONCLUDING REMARKS}

In this research project, we showed that patients that developed PHF in the setting of aortic valve replacement for AS had a poor long-term prognosis, regardless of whether they were considered to be at low or high risk preoperatively. We also showed that preoperative NT-proBNP was highest among patients with a pressure overload (like in AS) and next-highest among those with a volume overload (like in MR). In addition, we confirmed that NT-proBNP could predict severe PHF in patients with CAD and MR, but it was less predictive in patients with AS, at least in the short-term. NT-proBNP was also found to be predictive of short-term mortality among patients with $\mathrm{CAD}$. An intervention for AS elicited a rise in NT-proBNP, which was much more pronounced among patients that received SAVR, compared to those that received TAVI. However, after six months, the levels returned to preoperative levels, or below, in most patients. The pre- and early postoperative NT-proBNP levels were also shown to predict the one-year mortality. In the fourth study of this dissertation, we could not establish whether diastolic dysfunction, per se, was associated with long-term mortality; in contrast, both NT-proBNP and PHF had implications for long-term survival. 


\section{REFERENCES}

1. Howell NJ, Ashrafian H, Drury NE, Ranasinghe AM, Contractor H, Isackson H, et al. Glucose-insulin-potassium reduces the incidence of low cardiac output episodes after aortic valve replacement for aortic stenosis in patients with left ventricular hypertrophy: results from the Hypertrophy, Insulin, Glucose, and Electrolytes (HINGE) trial. Circulation. 2011;123(2):170-7.

2. Carabello BA, Paulus WJ. Aortic stenosis. Lancet (London, England). 2009;373(9667):956-66.

3. Pibarot P, Dumesnil JG. Prosthetic heart valves: selection of the optimal prosthesis and long-term management. Circulation. 2009;119(7):1034-48.

4. Bates ER. Treatment options in severe aortic stenosis. Circulation. 2011;124(3):355-9.

5. Lindblom D, Lindblom U, Qvist J, Lundstrom H. Long-term relative survival rates after heart valve replacement. Journal of the American College of Cardiology. 1990;15(3):566-73.

6. Ellenberger C, Sologashvili T, Cikirikcioglu M, Verdon G, Diaper J, Cassina T, et al. Risk factors of postcardiotomy ventricular dysfunction in moderate-to-high risk patients undergoing open-heart surgery. Annals of cardiac anaesthesia. 2017;20(3):287-96.

7. Vanky F, Hakanson E, Maros T, Svedjeholm R. Different characteristics of postoperative heart failure after surgery for aortic stenosis and coronary disease. Scandinavian cardiovascular journal : SCJ. 2004;38(3):152-8.

8. Vanky FB, Hakanson E, Svedjeholm R. Long-term consequences of postoperative heart failure after surgery for aortic stenosis compared with coronary surgery. The Annals of thoracic surgery. 2007;83(6):2036-43.

9. Chambers DJ. New solutions for the heart. An Update in Advanced Perioperative Protection2011.

10. Nashef SA, Roques F, Sharples LD, Nilsson J, Smith C, Goldstone AR, et al. EuroSCORE II. European journal of cardio-thoracic surgery : official journal of the European Association for Cardio-thoracic Surgery. 2012;41(4):734-44; discussion 44-5.

11. Buckberg GD, Hoffman JI, Coghlan HC, Nanda NC. Ventricular structurefunction relations in health and disease: Part I. The normal heart. European journal of cardio-thoracic surgery : official journal of the European Association for Cardio-thoracic Surgery. 2015;47(4):587-601.

12. Verhoeff K, Mitchell JR. Cardiopulmonary physiology: why the heart and lungs are inextricably linked. Advances in physiology education. 2017;41(3):348-53.

13. MacIver DH, Partridge JB, Agger P, Stephenson RS, Boukens BJD, Omann C, et al. The end of the unique myocardial band: Part II. Clinical and functional considerations. European journal of cardio-thoracic surgery : official journal of the European Association for Cardio-thoracic Surgery. 2018;53(1):120-8.

14. Stephenson RS, Agger P, Omann C, Sanchez-Quintana D, Jarvis JC, Anderson RH. Resolving the True Ventricular Mural Architecture. Journal of cardiovascular development and disease. 2018;5(2). 
15. Phibbs B. The human heart: a basic guide to heart disease. First edition ed: Lippincott-Raven Publishers; 1997.

16. Akinseye OA, Pathak A, Ibebuogu UN. Aortic Valve Regurgitation: A Comprehensive Review. Current problems in cardiology. 2018;43(8):315-34.

17. Bekeredjian R, Grayburn PA. Valvular heart disease: aortic regurgitation. Circulation. 2005;112(1):125-34.

18. You J, Wu J, Zhang Q, Ye Y, Wang S, Huang J, et al. Differential cardiac hypertrophy and signaling pathways in pressure versus volume overload. American journal of physiology Heart and circulatory physiology. 2018;314(3):H552-h62.

19. Roscani MG, Duarte JDC, Augusto GN, Salgueiro TRM, Meireles MN, Gobbi JIF, et al. Association Between Left Ventricle Diastolic Dysfunction and Unfavorable Prognostic Markers in Patients with Aortic Insufficiency. Journal of clinical and diagnostic research : JCDR. 2017;11(6):Oc09-oc11.

20. Thaden JJ, Nkomo VT, Enriquez-Sarano M. The global burden of aortic stenosis. Progress in cardiovascular diseases. 2014;56(6):565-71.

21. Pawade TA, Newby DE, Dweck MR. Calcification in Aortic Stenosis: The Skeleton Key. Journal of the American College of Cardiology. 2015;66(5):56177.

22. Izquierdo-Gomez MM, Hernandez-Betancor I, Garcia-Niebla J, Mari-Lopez B, Laynez-Cerdena I, Lacalzada-Almeida J. Valve Calcification in Aortic Stenosis: Etiology and Diagnostic Imaging Techniques. BioMed research international. 2017;2017:5178631.

23. Rader F, Sachdev E, Arsanjani R, Siegel RJ. Left ventricular hypertrophy in valvular aortic stenosis: mechanisms and clinical implications. The American journal of medicine. 2015;128(4):344-52.

24. Horstkotte D, Loogen F. The natural history of aortic valve stenosis. European heart journal. 1988;9 Suppl E:57-64.

25. January CT, Wann LS, Alpert JS, Calkins H, Cigarroa JE, Cleveland JC, Jr., et al. 2014 AHA/ACC/HRS guideline for the management of patients with atrial fibrillation: a report of the American College of Cardiology/American Heart Association Task Force on Practice Guidelines and the Heart Rhythm Society. Journal of the American College of Cardiology. 2014;64(21):e1-76.

26. Baumgartner H, Falk V, Bax JJ, De Bonis M, Hamm C, Holm PJ, et al. 2017 ESC/EACTS Guidelines for the management of valvular heart disease. European heart journal. 2017;38(36):2739-91.

27. Lindman BR, Clavel MA, Mathieu P, Iung B, Lancellotti P, Otto CM, et al. Calcific aortic stenosis. Nature reviews Disease primers. 2016;2:16006.

28. Nagueh SF. Non-invasive assessment of left ventricular filling pressure. European journal of heart failure. 2018;20(1):38-48.

29. Suga S, Nakao K, Hosoda K, Mukoyama M, Ogawa Y, Shirakami G, et al. Receptor selectivity of natriuretic peptide family, atrial natriuretic peptide, brain natriuretic peptide, and C-type natriuretic peptide. Endocrinology. 1992;130(1):229-39.

30. Tetsuji Sudoh KK, Naoto Minamino \& Hisayuki Matsuo. A new natriuretic peptide in porcine brain. Nature. 1988;332(3):889-16.

31. Fu S, Ping P, Zhu Q, Ye P, Luo L. Brain Natriuretic Peptide and Its Biochemical, Analytical, and Clinical Issues in Heart Failure: A Narrative Review. Frontiers in physiology. 2018;9:692. 
32. Hall C. Essential biochemistry and physiology of (NT-pro)BNP. European journal of heart failure. 2004;6(3):257-60.

33. Vanderheyden M, Goethals M, Verstreken S, De Bruyne B, Muller K, Van Schuerbeeck E, et al. Wall stress modulates brain natriuretic peptide production in pressure overload cardiomyopathy. Journal of the American College of Cardiology. 2004;44(12):2349-54.

34. Pemberton CJ, Johnson ML, Yandle TG, Espiner EA. Deconvolution analysis of cardiac natriuretic peptides during acute volume overload. Hypertension (Dallas, Tex : 1979). 2000;36(3):355-9.

35. Ponikowski P, Voors AA, Anker SD, Bueno H, Cleland JG, Coats AJ, et al. 2016 ESC Guidelines for the diagnosis and treatment of acute and chronic heart failure: The Task Force for the diagnosis and treatment of acute and chronic heart failure of the European Society of Cardiology (ESC). Developed with the special contribution of the Heart Failure Association (HFA) of the ESC. European journal of heart failure. 2016;18(8):891-975.

36. Yancy CW, Jessup M, Bozkurt B, Butler J, Casey DE, Jr., Colvin MM, et al. 2017 ACC/AHA/HFSA Focused Update of the 2013 ACCF/AHA Guideline for the Management of Heart Failure: A Report of the American College of Cardiology/American Heart Association Task Force on Clinical Practice Guidelines and the Heart Failure Society of America. Journal of the American College of Cardiology. 2017;70(6):776-803.

37. Cemri M, Arslan U, Kocaman SA, Cengel A. Relationship between N-terminal pro-B type natriuretic peptide and extensive echocardiographic parameters in mild to moderate aortic stenosis. Journal of postgraduate medicine. 2008;54(1):12-6.

38. Torres-Ramalho P, Araujo JP, Bettencourt P, Moura LM. Natriuretic peptides in aortic stenosis. Revista portuguesa de cardiologia : orgao oficial da Sociedade Portuguesa de Cardiologia $=$ Portuguese journal of cardiology : an official journal of the Portuguese Society of Cardiology. 2012;31(10):655-60.

39. Bergler-Klein J. Serial B-Type Natriuretic Peptide in Aortic Stenosis: A Practical Tool for Prediction of Outcome and Intervention Timing? The Canadian journal of cardiology. 2016;32(2):142-4.

40. Cerrahoglu M, Iskesen I, Tekin C, Onur E, Yildirim F, Sirin BH. N-terminal ProBNP levels can predict cardiac failure after cardiac surgery. Circulation journal : official journal of the Japanese Circulation Society. 2007;71(1):79-83.

41. Cuthbertson BH, Croal BL, Rae D, Gibson PH, McNeilly JD, Jeffrey RR, et al. Nterminal pro-B-type natriuretic peptide levels and early outcome after cardiac surgery: a prospective cohort study. British journal of anaesthesia. 2009;103(5):647-53.

42. Liu H, Wang C, Liu L, Zhuang Y, Yang X, Zhang Y. Perioperative application of $\mathrm{N}$-terminal pro-brain natriuretic peptide in patients undergoing cardiac surgery. Journal of cardiothoracic surgery. 2013;8:1.

43. Lurati Buse GA, Koller MT, Burkhart C, Seeberger MD, Filipovic M. The predictive value of preoperative natriuretic peptide concentrations in adults undergoing surgery: a systematic review and meta-analysis. Anesthesia and analgesia. 2011;112(5):1019-33.

44. Young YR, Sheu BF, Li WC, Hsieh TM, Hung CW, Chang SS, et al. Predictive value of plasma brain natriuretic peptide for postoperative cardiac complications-a systemic review and meta-analysis. Journal of critical care. 2014;29(4):696.e110. 
45. Bergler-Klein J, Mundigler G, Pibarot P, Burwash IG, Dumesnil JG, Blais C, et al. B-type natriuretic peptide in low-flow, low-gradient aortic stenosis: relationship to hemodynamics and clinical outcome: results from the Multicenter Truly or Pseudo-Severe Aortic Stenosis (TOPAS) study. Circulation. 2007;115(22):2848-55.

46. Eliasdottir SB, Klemenzson G, Torfason B, Valsson F. Brain natriuretic peptide is a good predictor for outcome in cardiac surgery. Acta anaesthesiologica Scandinavica. 2008;52(2):182-7.

47. Weber M, Hausen M, Arnold R, Nef H, Moellman H, Berkowitsch A, et al. Prognostic value of $\mathrm{N}$-terminal pro-B-type natriuretic peptide for conservatively and surgically treated patients with aortic valve stenosis. Heart (British Cardiac Society). 2006;92(11):1639-44.

48. Litton E, Ho KM. The use of pre-operative brain natriuretic peptides as a predictor of adverse outcomes after cardiac surgery: a systematic review and meta-analysis. European journal of cardio-thoracic surgery : official journal of the European Association for Cardio-thoracic Surgery. 2012;41(3):525-34.

49. Frederiksen CA, Juhl-Olsen P, Jakobsen CJ, Sloth E. Echocardiographic evaluation of systolic and diastolic function: a preoperative study of correlation with serum NT-proBNP. Journal of cardiothoracic and vascular anesthesia. 2012;26(2):197-203.

50. Galema TW, Yap SC, Geleijnse ML, van Thiel RJ, Lindemans J, ten Cate FJ, et al. Early detection of left ventricular dysfunction by Doppler tissue imaging and $\mathrm{N}$-terminal pro-B-type natriuretic peptide in patients with symptomatic severe aortic stenosis. J Am Soc Echocardiogr. 2008;21(3):257-61.

51. Kupari M, Turto H, Lommi J, Makijarvi M, Parikka H. Transcardiac gradients of $\mathrm{N}$-terminal B-type natriuretic peptide in aortic valve stenosis. European journal of heart failure. 2005;7(5):809-14.

52. Poh KK, Chan MY, Yang H, Yong QW, Chan YH, Ling LH. Prognostication of valvular aortic stenosis using tissue Doppler echocardiography: underappreciated importance of late diastolic mitral annular velocity. J Am Soc Echocardiogr. 2008;21(5):475-81.

53. Mitter SS, Shah SJ, Thomas JD. A Test in Context: E/A and E/e' to Assess Diastolic Dysfunction and LV Filling Pressure. Journal of the American College of Cardiology. 2017;69(11):1451-64.

54. Lund O, Flo C, Jensen FT, Emmertsen K, Nielsen TT, Rasmussen BS, et al. Left ventricular systolic and diastolic function in aortic stenosis. Prognostic value after valve replacement and underlying mechanisms. European heart journal. 1997;18(12):1977-87.

55. Zaid RR, Barker CM, Little SH, Nagueh SF. Pre- and post-operative diastolic dysfunction in patients with valvular heart disease: diagnosis and therapeutic implications. Journal of the American College of Cardiology. 2013;62(21):192230 .

56. Kaw R, Hernandez AV, Pasupuleti V, Deshpande A, Nagarajan V, Bueno H, et al. Effect of diastolic dysfunction on postoperative outcomes after cardiovascular surgery: A systematic review and meta-analysis. The Journal of thoracic and cardiovascular surgery. 2016;152(4):1142-53.

57. Kampaktsis PN, Kokkinidis DG, Wong SC, Vavuranakis M, Skubas NJ, Devereux RB. The role and clinical implications of diastolic dysfunction in aortic stenosis. Heart (British Cardiac Society). 2017;103(19):1481-7. 
58. Gjertsson P, Caidahl K, Farasati M, Oden A, Bech-Hanssen O. Preoperative moderate to severe diastolic dysfunction: a novel Doppler echocardiographic long-term prognostic factor in patients with severe aortic stenosis. The Journal of thoracic and cardiovascular surgery. 2005;129(4):890-6.

59. Gjertsson P, Caidahl K, Bech-Hanssen O. Left ventricular diastolic dysfunction late after aortic valve replacement in patients with aortic stenosis. The American journal of cardiology. 2005;96(5):722-7.

60. Biner S, Rafique AM, Goykhman P, Morrissey RP, Naghi J, Siegel RJ. Prognostic value of E/E' ratio in patients with unoperated severe aortic stenosis. JACC Cardiovascular imaging. 2010;3(9):899-907.

61. Nakagawa D, Suwa M, Ito T, Kono T, Kitaura Y. Postoperative outcome in aortic stenosis with diastolic heart failure compared to one with depressed systolic function. International heart journal. 2007;48(1):79-86.

62. Muratori M, Fusini L, Tamborini G, Gripari P, Delgado V, Marsan NA, et al. Sustained favourable haemodynamics 1 year after TAVI: improvement in NYHA functional class related to improvement of left ventricular diastolic function. Eur Heart J Cardiovasc Imaging. 2016;17(11):1269-78.

63. Carabello BA. Introduction to aortic stenosis. Circulation research. 2013;113(2):179-85.

64. DD G. Aquired aortic valve disease. In: Sabiston D C SF, editor. Surgery of the chest. 6 ed ed. Philadelphia: W. B. Saunders Company; 1995.

65. Miller S, Flynn BC. Valvular heart disease and postoperative considerations. Seminars in cardiothoracic and vascular anesthesia. 2015;19(2):130-42.

66. Cribier A, Eltchaninoff H, Bash A, Borenstein N, Tron C, Bauer F, et al. Percutaneous transcatheter implantation of an aortic valve prosthesis for calcific aortic stenosis: first human case description. Circulation. 2002;106(24):3006-8.

67. Faxon DP, Williams DO. Interventional Cardiology: Current Status and Future Directions in Coronary Disease and Valvular Heart Disease. Circulation. 2016;133(25):2697-711.

68. Hoffmann G, Abraham-Westphal S, Attmann T, Frank D, Lutter G, Cremer J, et al. Impact of Patient-Prosthesis Mismatch following Aortic Valve Replacement on Long-Term Survival and Quality of Life. The Thoracic and cardiovascular surgeon. 2018.

69. Pibarot P, Dumesnil JG. Prosthesis-patient mismatch: definition, clinical impact, and prevention. Heart (British Cardiac Society). 2006;92(8):1022-9.

70. Chiam PT, Ewe SH. An update on complications associated with transcatheter aortic valve implantation: stroke, paravalvular leak, atrioventricular block and perforation. Future cardiology. 2013;9(5):733-47.

71. Rodes-Cabau J, Gutierrez M, Bagur R, De Larochelliere R, Doyle D, Cote M, et al. Incidence, predictive factors, and prognostic value of myocardial injury following uncomplicated transcatheter aortic valve implantation. Journal of the American College of Cardiology. 2011;57(20):1988-99.

72. Nilsson L, Appel CF, Hultkvist H, Vanky F. Evaluation of the Valve Academic Research Consortium-2 Criteria for Myocardial Infarction in Transcatheter Aortic Valve Implantation: A Prospective Observational Study. PloS one. 2015;10(6):e0130423.

73. Attarian DE, Jones RN, Currie WD, Hill RC, Sink JD, Olsen CO, et al. Characteristics of chronic left ventricular hypertrophy induced by subcoronary valvular aortic stenosis. II. Response to ischemia. The Journal of thoracic and cardiovascular surgery. 1981;81(3):389-95. 
74. Lee $\mathrm{CH}, \mathrm{Ju} \mathrm{MH}$, Kim JB, Chung $\mathrm{CH}$, Jung SH, Choo SJ, et al. Myocardial injury following aortic valve replacement for severe aortic stenosis: risk factor of postoperative myocardial injury and its impact on long-term outcomes. The Korean journal of thoracic and cardiovascular surgery. 2014;47(3):233-9.

75. Pietersen HG, Langenberg CJ, Geskes G, Kester A, de Lange S, Van der Vusse GJ, et al. Myocardial substrate uptake and oxidation during and after routine cardiac surgery. The Journal of thoracic and cardiovascular surgery. 1999;118(1):71-80.

76. Lomivorotov VV, Efremov SM, Kirov MY, Fominskiy EV, Karaskov AM. LowCardiac-Output Syndrome After Cardiac Surgery. Journal of cardiothoracic and vascular anesthesia. 2017;31(1):291-308.

77. O'Connor GT, Birkmeyer JD, Dacey LJ, Quinton HB, Marrin CA, Birkmeyer NJ, et al. Results of a regional study of modes of death associated with coronary artery bypass grafting. Northern New England Cardiovascular Disease Study Group. The Annals of thoracic surgery. 1998;66(4):1323-8.

78. Maganti MD, Rao V, Borger MA, Ivanov J, David TE. Predictors of low cardiac output syndrome after isolated aortic valve surgery. Circulation. 2005;112(9 Suppl):I448-52.

79. Elahi MM, Chuang A, Ewing MJ, Choi CH, Grant PW, Matata BM. One problem two issues! Left ventricular systolic and diastolic dysfunction in aortic stenosis. Annals of translational medicine. 2014;2(1):10.

80. Capoulade R, Le Ven F, Clavel MA, Dumesnil JG, Dahou A, Thebault C, et al. Echocardiographic predictors of outcomes in adults with aortic stenosis. Heart (British Cardiac Society). 2016;102(12):934-42.

81. Toumpoulis IK, Anagnostopoulos CE, Toumpoulis SK, DeRose JJ, Jr., Swistel DG. EuroSCORE predicts long-term mortality after heart valve surgery. The Annals of thoracic surgery. 2005;79(6):1902-8.

82. Vanky FB, Hakanson E, Tamas E, Svedjeholm R. Risk factors for postoperative heart failure in patients operated on for aortic stenosis. The Annals of thoracic surgery. 2006;81(4):1297-304.

83. Balderas-Munoz K, Rodriguez-Zanella H, Fritche-Salazar JF, Avila-Vanzzini N, Juarez Orozco LE, Arias-Godinez JA, et al. Improving risk assessment for postsurgical low cardiac output syndrome in patients without severely reduced ejection fraction undergoing open aortic valve replacement. The role of global longitudinal strain and right ventricular free wall strain. The international journal of cardiovascular imaging. 2017;33(10):1483-9.

84. Toller WG, Metzler H. Acute perioperative heart failure. Current opinion in anaesthesiology. 2005;18(2):129-35.

85. Rudiger A, Businger F, Streit M, Schmid ER, Maggiorini M, Follath F. Presentation and outcome of critically ill medical and cardiac-surgery patients with acute heart failure. Swiss medical weekly. 2009;139(7-8):110-6.

86. Mebazaa A, Pitsis AA, Rudiger A, Toller W, Longrois D, Ricksten SE, et al. Clinical review: practical recommendations on the management of perioperative heart failure in cardiac surgery. Critical care (London, England). 2010;14(2):201.

87. Svedjeholm R, Hakanson E, Szabo Z. Routine SvO2 measurement after CABG surgery with a surgically introduced pulmonary artery catheter. European journal of cardio-thoracic surgery : official journal of the European Association for Cardio-thoracic Surgery. 1999;16(4):450-7. 
88. Maisel A, Mueller C, Adams K, Jr., Anker SD, Aspromonte N, Cleland JG, et al. State of the art: using natriuretic peptide levels in clinical practice. European journal of heart failure. 2008;10(9):824-39.

89. Roberts E, Ludman AJ, Dworzynski K, Al-Mohammad A, Cowie MR, McMurray $\mathrm{JJ}$, et al. The diagnostic accuracy of the natriuretic peptides in heart failure: systematic review and diagnostic meta-analysis in the acute care setting. BMJ (Clinical research ed). 2015;350:h910.

90. Choong CK, Sergeant P, Nashef SA, Smith JA, Bridgewater B. The EuroSCORE risk stratification system in the current era: how accurate is it and what should be done if it is inaccurate? European journal of cardio-thoracic surgery : official journal of the European Association for Cardio-thoracic Surgery. 2009;35(1):5961.

91. Lang RM, Badano LP, Mor-Avi V, Afilalo J, Armstrong A, Ernande L, et al. Recommendations for cardiac chamber quantification by echocardiography in adults: an update from the American Society of Echocardiography and the European Association of Cardiovascular Imaging. J Am Soc Echocardiogr. 2015;28(1):1-39.e14.

92. Nagueh SF, Smiseth OA, Appleton CP, Byrd BF, 3rd, Dokainish H, Edvardsen T, et al. Recommendations for the Evaluation of Left Ventricular Diastolic Function by Echocardiography: An Update from the American Society of Echocardiography and the European Association of Cardiovascular Imaging. Eur Heart J Cardiovasc Imaging. 2016;17(12):1321-60.

93. Nagueh SF, Smiseth OA, Appleton CP, Byrd BF, 3rd, Dokainish H, Edvardsen T, et al. Recommendations for the Evaluation of Left Ventricular Diastolic Function by Echocardiography: An Update from the American Society of Echocardiography and the European Association of Cardiovascular Imaging. J Am Soc Echocardiogr. 2016;29(4):277-314.

94. Brutsaert DL, Sys SU, Gillebert TC. Diastolic failure: pathophysiology and therapeutic implications. Journal of the American College of Cardiology. 1993;22(1):318-25.

95. Tamas E, Nylander E. Decision support for assessment of left ventricular diastolic function. Physiological reports. 2018;6(16):e13815.

96. Hakanson E, Svedjeholm R, Vanhanen I. Physiologic aspects in postoperative cardiac patients. The Annals of thoracic surgery. 1995;59(2 Suppl):S12-4.

97. Holm J, Hakanson E, Vanky F, Svedjeholm R. Mixed venous oxygen saturation predicts short- and long-term outcome after coronary artery bypass grafting surgery: a retrospective cohort analysis. British journal of anaesthesia. 2011;107(3):344-50.

98. Holm J, Hakanson RE, Vanky F, Svedjeholm R. Mixed venous oxygen saturation is a prognostic marker after surgery for aortic stenosis. Acta anaesthesiologica Scandinavica. 2010;54(5):589-95.

99. Svedjeholm R, Vidlund M, Vanhanen I, Hakanson E. A metabolic protective strategy could improve long-term survival in patients with LV-dysfunction undergoing CABG. Scandinavian cardiovascular journal : SCJ. 2010;44(1):45-58.

100. SCN S. Nonparametric statistics for the behavioral sciences. New York: McGrawHill; 1998. p. 213-5. 
101. Perez Vela JL, Martin Benitez JC, Carrasco Gonzalez M, de la Cal Lopez MA, Hinojosa Perez R, Sagredo Meneses V, et al. [Summary of the consensus document: "Clinical practice guide for the management of low cardiac output syndrome in the postoperative period of heart surgery"]. Medicina intensiva. 2012;36(4):277-87.

102. Coronel R, de Groot JR, van Lieshout JJ. Defining heart failure. Cardiovascular research. 2001;50(3):419-22.

103. Hunt SA, Abraham WT, Chin MH, Feldman AM, Francis GS, Ganiats TG, et al. ACC/AHA 2005 Guideline Update for the Diagnosis and Management of Chronic Heart Failure in the Adult: a report of the American College of Cardiology/American Heart Association Task Force on Practice Guidelines (Writing Committee to Update the 2001 Guidelines for the Evaluation and Management of Heart Failure): developed in collaboration with the American College of Chest Physicians and the International Society for Heart and Lung Transplantation: endorsed by the Heart Rhythm Society. Circulation. 2005;112(12):e154-235.

104. Hunt SA, Abraham WT, Chin MH, Feldman AM, Francis GS, Ganiats TG, et al. 2009 focused update incorporated into the ACC/AHA 2005 Guidelines for the Diagnosis and Management of Heart Failure in Adults: a report of the American College of Cardiology Foundation/American Heart Association Task Force on Practice Guidelines: developed in collaboration with the International Society for Heart and Lung Transplantation. Circulation. 2009;119(14):e391-479.

105. Ding WH, Lam YY, Duncan A, Li W, Lim E, Kaya MG, et al. Predictors of survival after aortic valve replacement in patients with low-flow and high-gradient aortic stenosis. European journal of heart failure. 2009;11(9):897-902.

106. Berendes E, Schmidt C, Van Aken H, Hartlage MG, Rothenburger M, Wirtz S, et al. A-type and B-type natriuretic peptides in cardiac surgical procedures. Anesthesia and analgesia. 2004;98(1):11-9, table of contents.

107. Cuthbertson BH, Croal BL, Rae D, Harrild K, Gibson PH, Prescott GJ, et al. Nterminal pro-B-type natriuretic peptide concentrations and long-term outcome after cardiac surgery: a prospective cohort study. British journal of anaesthesia. 2013;110(2):214-21.

108. Fellahi JL, Daccache G, Makroum Y, Massetti M, Gerard JL, Hanouz JL. The prognostic value of B-type natriuretic peptide after cardiac surgery: a comparative study between coronary artery bypass graft surgery and aortic valve replacement. Journal of cardiothoracic and vascular anesthesia. 2012;26(4):624-30.

109. Georges A, Forestier F, Valli N, Plogin A, Janvier G, Bordenave L. Changes in type B natriuretic peptide (BNP) concentrations during cardiac valve replacement. European journal of cardio-thoracic surgery : official journal of the European Association for Cardio-thoracic Surgery. 2004;25(6):941-5.

110. Jogia PM, Kalkoff M, Sleigh JW, Bertinelli A, La Pine M, Richards AM, et al. NT-pro BNP secretion and clinical endpoints in cardiac surgery intensive care patients. Anaesthesia and intensive care. 2007;35(3):363-9.

111. Singh S, Kapoor A, Agarwal SK, Pande S, Sinha A, Rai H. Differential Release Kinetics of Cardiac Biomarkers in Patients Undergoing Valve Replacement Surgery. Journal of cardiac surgery. 2014;29(2):134-40.

112. Singh S, Kapoor A, Agarwal SK, Pande S, Sinha A, Rai H, et al. Differential release kinetics of cardiac biomarkers in off-pump coronary bypass. Asian cardiovascular \& thoracic annals. 2014;22(6):674-81. 
113. Vikholm P, Schiller P, Hellgren L. Preoperative brain natriuretic peptide predicts late mortality and functional class but not hospital readmission after cardiac surgery. Journal of cardiothoracic and vascular anesthesia. 2014;28(3):520-7.

114. Chenevier-Gobeaux C, Claessens YE, Voyer S, Desmoulins D, Ekindjian OG. Influence of renal function on N-terminal pro-brain natriuretic peptide (NTproBNP) in patients admitted for dyspnoea in the Emergency Department: comparison with brain natriuretic peptide (BNP). Clinica chimica acta; international journal of clinical chemistry. 2005;361(1-2):167-75.

115. Jo YY, Kwak YL, Lee J, Choi YS. Relationship between N-terminal pro-B-type natriuretic peptide and renal function: the effects on predicting early outcome after off-pump coronary artery bypass surgery. Korean journal of anesthesiology. 2011;61(1):35-41.

116. Redfield MM, Rodeheffer RJ, Jacobsen SJ, Mahoney DW, Bailey KR, Burnett JC, Jr. Plasma brain natriuretic peptide concentration: impact of age and gender. Journal of the American College of Cardiology. 2002;40(5):976-82.

117. Clerico A, Giannoni A, Vittorini S, Emdin M. The paradox of low BNP levels in obesity. Heart failure reviews. 2012;17(1):81-96.

118. Magne J, Mahjoub H, Pierard LA, O'Connor K, Pirlet C, Pibarot P, et al. Prognostic importance of brain natriuretic peptide and left ventricular longitudinal function in asymptomatic degenerative mitral regurgitation. Heart (British Cardiac Society). 2012;98(7):584-91.

119. Marechaux S, Hattabi M, Juthier F, Neicu DV, Richardson M, Carpentier E, et al. Clinical and echocardiographic correlates of plasma B-type natriuretic peptide levels in patients with aortic valve stenosis and normal left ventricular ejection fraction. Echocardiography (Mount Kisco, NY). 2011;28(7):695-702.

120. Pascual-Figal DA, Antolinos MJ, Bayes-Genis A, Casas T, Nicolas F, Valdes M. B-type natriuretic peptide release in the coronary effluent after acute transient ischaemia in humans. Heart (British Cardiac Society). 2007;93(9):1077-80.

121. Xu L, Qian W, Li W, Liu J, He H, Li G, et al. The severity of coronary artery disease and reversible ischemia revealed by $\mathrm{N}$-terminal pro-brain natriuretic peptide in patients with unstable angina and preserved left ventricular function. Peptides. 2014;52:143-8.

122. Cuthbertson BH, McKeown A, Croal BL, Mutch WJ, Hillis GS. Utility of B-type natriuretic peptide in predicting the level of peri- and postoperative cardiovascular support required after coronary artery bypass grafting. Critical care medicine. 2005;33(2):437-42.

123. Fox AA, Shernan SK, Collard CD, Liu KY, Aranki SF, DeSantis SM, et al. Preoperative B-type natriuretic peptide is as independent predictor of ventricular dysfunction and mortality after primary coronary artery bypass grafting. The Journal of thoracic and cardiovascular surgery. 2008;136(2):452-61.

124. Holm J, Vidlund M, Vanky F, Friberg O, Hakanson E, Svedjeholm R. Preoperative NT-proBNP independently predicts outcome in patients with acute coronary syndrome undergoing CABG. Scandinavian cardiovascular journal Supplement. 2013;47(1):28-35.

125. Holm J, Vidlund M, Vanky F, Friberg O, Hakanson E, Walther S, et al. EuroSCORE II and N-terminal pro-B-type natriuretic peptide for risk evaluation: an observational longitudinal study in patients undergoing coronary artery bypass graft surgery. British journal of anaesthesia. 2014;113(1):75-82. 
126. Pedrazzini GB, Masson S, Latini R, Klersy C, Rossi MG, Pasotti E, et al. Comparison of brain natriuretic peptide plasma levels versus logistic EuroSCORE in predicting in-hospital and late postoperative mortality in patients undergoing aortic valve replacement for symptomatic aortic stenosis. The American journal of cardiology. 2008;102(6):749-54.

127. Kolh P, Windecker S, Alfonso F, Collet JP, Cremer J, Falk V, et al. 2014 ESC/EACTS Guidelines on myocardial revascularization: the Task Force on Myocardial Revascularization of the European Society of Cardiology (ESC) and the European Association for Cardio-Thoracic Surgery (EACTS). Developed with the special contribution of the European Association of Percutaneous Cardiovascular Interventions (EAPCI). European journal of cardio-thoracic surgery : official journal of the European Association for Cardio-thoracic Surgery. 2014;46(4):517-92.

128. Vahanian A, Alfieri O, Andreotti F, Antunes MJ, Baron-Esquivias G, Baumgartner $\mathrm{H}$, et al. Guidelines on the management of valvular heart disease (version 2012): the Joint Task Force on the Management of Valvular Heart Disease of the European Society of Cardiology (ESC) and the European Association for Cardio-Thoracic Surgery (EACTS). European journal of cardiothoracic surgery : official journal of the European Association for Cardio-thoracic Surgery. 2012;42(4):S1-44.

129. Gerber IL, Stewart RA, French JK, Legget ME, Greaves SC, West TM, et al. Associations between plasma natriuretic peptide levels, symptoms, and left ventricular function in patients with chronic aortic regurgitation. The American journal of cardiology. 2003;92(6):755-8.

130. Ribeiro HB, Urena M, Le Ven F, Nombela-Franco L, Allende R, Clavel MA, et al. Long-term prognostic value and serial changes of plasma $\mathrm{N}$-terminal prohormone B-type natriuretic peptide in patients undergoing transcatheter aortic valve implantation. The American journal of cardiology. 2014;113(5):851-9.

131. Sherif MA, Abdel-Wahab M, Awad O, Geist V, El-Shahed G, Semmler R, et al. Early hemodynamic and neurohormonal response after transcatheter aortic valve implantation. American heart journal. 2010;160(5):862-9.

132. Spargias K, Polymeros S, Dimopoulos A, Manginas A, Pavlides G, Balanika M, et al. The predictive value and evolution of $\mathrm{N}$-terminal pro-B-type natriuretic peptide levels following transcutaneous aortic valve implantation. Journal of interventional cardiology. 2011;24(5):462-9.

133. Bergler-Klein J. Natriuretic peptides in the management of aortic stenosis. Current cardiology reports. 2009;11(2):85-93.

134. Daniels LB, Maisel AS. Natriuretic peptides. Journal of the American College of Cardiology. 2007;50(25):2357-68.

135. Fox AA, Body SC. Assessment of preoperative B-type natriuretic peptide in adult surgeries: is it useful? Anesthesia and analgesia. 2011;112(5):1005-7.

136. Hutfless R, Kazanegra R, Madani M, Bhalla MA, Tulua-Tata A, Chen A, et al. Utility of B-type natriuretic peptide in predicting postoperative complications and outcomes in patients undergoing heart surgery. Journal of the American College of Cardiology. 2004;43(10):1873-9.

137. Provenchere S, Berroeta C, Reynaud C, Baron G, Poirier I, Desmonts JM, et al. Plasma brain natriuretic peptide and cardiac troponin I concentrations after adult cardiac surgery: association with postoperative cardiac dysfunction and 1-year mortality. Critical care medicine. 2006;34(4):995-1000. 
138. Kefer J, Beauloye C, Astarci P, Renkin J, Glineur D, Dekleermaeker A, et al. Usefulness of B-type natriuretic peptide to predict outcome of patients treated by transcatheter aortic valve implantation. The American journal of cardiology. 2010;106(12):1782-6.

139. Lopez-Otero D, Trillo-Nouche R, Gude F, Cid-Alvarez B, Ocaranza-Sanchez R, Alvarez MS, et al. Pro B-type natriuretic peptide plasma value: a new criterion for the prediction of short- and long-term outcomes after transcatheter aortic valve implantation. International journal of cardiology. 2013;168(2):1264-8.

140. Seiffert M, Sinning JM, Meyer A, Wilde S, Conradi L, Vasa-Nicotera M, et al. Development of a risk score for outcome after transcatheter aortic valve implantation. Clinical research in cardiology : official journal of the German Cardiac Society. 2014;103(8):631-40.

141. Pfister R, Wahlers T, Baer FM, Scherner M, Strauch J, Erdmann E. Utility of NTpro-BNP in patients undergoing transapical aortic valve replacement. Clinical research in cardiology : official journal of the German Cardiac Society. 2010;99(5):301-7.

142. Metkus TS, Suarez-Pierre A, Crawford TC, Lawton JS, Goeddel L, Dodd OJ, et al. Diastolic dysfunction is common and predicts outcome after cardiac surgery. Journal of cardiothoracic surgery. 2018;13(1):67.

143. Selmeryd J, Henriksen E, Leppert J, Hedberg P. Interstudy heterogeneity of definitions of diastolic dysfunction severely affects reported prevalence. Eur Heart J Cardiovasc Imaging. 2016;17(8):892-9.

144. Villari B, Vassalli G, Monrad ES, Chiariello M, Turina M, Hess OM. Normalization of diastolic dysfunction in aortic stenosis late after valve replacement. Circulation. 1995;91(9):2353-8.

145. Fan J, Ma J, Xia N, Sun L, Li B, Liu H. Clinical Value of Combined Detection of CK-MB, MYO, cTnI and Plasma NT-proBNP in Diagnosis of Acute Myocardial Infarction. Clinical laboratory. 2017;63(3):427-33.

146. Staub D, Jonas N, Zellweger MJ, Nusbaumer C, Wild D, Pfisterer ME, et al. Use of N-terminal pro-B-type natriuretic peptide to detect myocardial ischemia. The American journal of medicine. 2005;118(11):1287.

147. Boer BP, Vieira ML, Sampaio RO, Abensur H, Oliveira AG, Fernandes JR, et al. Correlation to NT-ProBNP and remodeling after cardiac surgery. Arquivos brasileiros de cardiologia. 2013;100(5):469-75.

148. Mannacio V, Antignano A, De Amicis V, Di Tommaso L, Giordano R, Iannelli G, et al. B-type natriuretic peptide as a biochemical marker of left ventricular diastolic function: assessment in asymptomatic patients 1 year after valve replacement for aortic stenosis. Interactive cardiovascular and thoracic surgery. 2013;17(2):371-7.

149. Grewal J, McKelvie R, Lonn E, Tait P, Carlsson J, Gianni M, et al. BNP and NTproBNP predict echocardiographic severity of diastolic dysfunction. European journal of heart failure. 2008;10(3):252-9.

150. Gumauskiene B, Krivickiene A, Jonkaitiene R, Vaskelyte JJ, Siudikas A, Ereminiene E. Impact of Left Ventricular Diastolic Dysfunction and Biomarkers on Pulmonary Hypertension in Patients with Severe Aortic Stenosis. Medicina (Kaunas, Lithuania). 2018;54(4).

151. Chin CW, Djohan AH, Lang CC. The role of cardiac biochemical markers in aortic stenosis. Biomarkers : biochemical indicators of exposure, response, and susceptibility to chemicals. 2016;21(4):316-27. 
152. Russo I, Frangogiannis NG. Diabetes-associated cardiac fibrosis: Cellular effectors, molecular mechanisms and therapeutic opportunities. Journal of molecular and cellular cardiology. 2016;90:84-93.

153. Hultkvist H, Vanky F, Svedjeholm R. The combined impact of postoperative heart failure and EuroSCORE on long-term outcome after surgery for aortic stenosis. The Journal of heart valve disease. 2011;20(6):633-8.

154. Lancellotti P, Galderisi M, Edvardsen T, Donal E, Goliasch G, Cardim N, et al. Echo-Doppler estimation of left ventricular filling pressure: results of the multicentre EACVI Euro-Filling study. Eur Heart J Cardiovasc Imaging. 2017;18(9):961-8. 


\section{Papers}

The papers associated with this thesis have been removed for copyright reasons. For more details about these see:

http://urn.kb.se/resolve?urn=urn:nbn:se:liu:diva-156719 


\section{FACULTY OF MEDICINE AND HEALTH SCIENCES}

Linköping University Medical Dissertations No. 1680, 2019

Department of Medical and Health Sciences

Linköping University

SE-581 83 Linköping, Sweden

www.liu.se 